\title{
EDYCJA ŹRÓDŁOWA
}

TOMASZ KRZYŻOWSKI, Polska Akademia Umiejętności

ORCID: 0000-0001-7193-5661

krzyzowskit@interia.pl

\section{KSIĄDZ ADAM ROSZKO-BOGDANOWICZ (1898-1941) WE WSPOMNIENIACH MARII KAPRI (1894-1985)}

STRESZCZENIE: Bohater publikowanych wspomnień ks. Adam Roszko-Bogdanowicz urodził się 12 VII 1898 r. w Dolinianach w rodzinie ormiańskiej Stanisława i Wandy de Oroszeny Bohdanowicz, ukończył gimnazjum we Lwowie i Seminarium Duchowne obrządku łacińskiego tamże, w 1920 r. przyjął święcenia kapłańskie z rąk arcybiskupa ormiańskiego Józefa Teodorowicza. Należał do grona organizatorów Biblioteki Wiedzy Religijnej w Warszawie (1920-1923), następnie był wikariuszem katedry ormiańskiej we Lwowie (1923-1927), administratorem parafii w Horodence na Pokuciu (19271935), od 1933 r. kanonikiem gremialnym kapituły ormiańskiej we Lwowie oraz redaktorem czasopisma teologicznego „Gregoriana” (1935-1938). Zasłynął jako ceniony duszpasterz, katecheta i rekolekcjonista, niestrudzony spowiednik i kierownik duchowy, patriota, publicysta oraz wydawca literatury religijnej. W okresie II wojny światowej włączył się w działalność patriotyczną w Związku Walki Zbrojnej, dlatego w 1940 r. został aresztowany przez NKWD i skazany na karę śmierci, której uniknął. Przebywał w więzieniu na ul. Kazimierzowskiej (tzw. „Brygidki”) we Lwowie, gdzie został zamordowany przez Sowietów 24 VI 1941 r. Autorkę wspomnień Marię Kapri (1894-1985) łączyła z ks. Adamem Roszko-Bogdanowiczem wieloletnia przyjaźń. Wymieniali poglądy na temat szeroko pojętego życia religijnego, pracy zawodowej, aktualnych problemów i trudności. Dotychczas nie opracowano rzetelnej biografii ks. Adama Bogdanowicza, dlatego opublikowane wspomnienia dostarczają wielu ciekawych i nieznanych dotychczas szczegółów z jego życia i działalności religijnej, społecznej i patriotycznej.

SŁOWA KLUCZE: ks. Adam Bogdanowicz, Maria Kapri, Ormianie polscy, Kościół ormiański.

\section{MARIA KAPRI'S MEMOIRS OF FATHER ADAM ROSZKO-BOGDANOWICZ (1898-1941)}

ABSTRACT: The hero of these memoirs, father Adam Roszko-Bogdanowicz, was born on July 12, 1898, in Dolininy into the Armenian family of Stanislav and Wanda de Oroszena Bohdanowicz. He finished middle school in Lviv and the Latin Seminary there, and was ordained a priest in 1920 by Armenian Archbishop Józef Teodorowicz. 
He was one of the organizers of the Library of Religious Knowledge in Warsaw (1920-1923), then he was vicar of the Armenian cathedral in Lvov (1923-1927), administrator of the parish in Horodenka in Pokucie (1927-1935), from 1933 a general canon of the Armenian chapter in Lvov and editor of the theological journal "Gregoriana" (1935-1938). He became known as a valued pastor, catechist and retreat leader, tireless confessor and spiritual director, patriot, journalist and publisher of religious literature. During World War II, he became involved in patriotic activities in the Union for Armed Struggle, and was arrested by the NKVD in 1940 and sentenced to death, which he avoided. He was held in the prison on Kazimierzowska Street (the socalled "Brygidki") in Lviv, where he was murdered by the Soviets on June 24, 1941. They exchanged views on a wide range of religious life, professional work, current problems and difficulties. A reliable biography of father Adam Bogdanowicz has not been compiled so far, therefore the published memoirs provide many interesting and previously unknown details of his life and religious, social and patriotic activities.

KEYWORDS: Rev. Adam Bogdanowicz, Maria Kapri, Polish Armenians, Armenian Church.

Translated by Dominik Jemielita

\section{Wprowadzenie}

Przypadająca w bieżącym roku 80. rocznica śmierci ks. Adama Roszko-Bogdanowicza stwarza dobrą okazję do przypomnienia tej zasłużonej dla Ormian i Kościoła w Polsce postaci. Bohater publikowanych poniżej wspomnień był kapłanem archidiecezji ormiańskokatolickiej we Lwowie, znanym i cenionym duszpasterzem, katechetą i rekolekcjonistą, niestrudzonym spowiednikiem i kierownikiem duchowym, patriotą, publicystą oraz wydawcą literatury religijnej. Inteligentny, oczytany, z poczuciem humoru. Jego wystąpienia cieszyły się popularnością, gdyż umiał trafić do słuchaczy i przedstawić w sposób zrozumiały trudne zagadnienia. Przy czym skupiał się na kwestiach w życiu katolika fundamentalnych i zarazem praktycznych. Każdą wolną chwilę wykorzystywał na lekturę fachowej literatury, modlitwę i pomoc innym. Treści, które poruszał na konferencjach i pogadankach dla młodzieży wykraczały poza epokę dwudziestolecia międzywojennego i zostały podjęte dopiero w nowej odsłonie kilka dziesięcioleci później, w okresie posoborowym. Za swoją działalność patriotyczną w okresie II wojny światowej zapłacił najwyższą cenę oddając życie za ojczyznę i wiarę.

Ks. Bogdanowicz nie doczekał się jak dotąd rzetelnej biografii charakteryzującej jego życie i działalność na niwie kościelnej i społecznej. Jego postać pojawia się przeważnie w kontekście dziejów lwowskiej 
archidiecezji ormiańskokatolickiej, bądź wydarzeń z okresu II wojny światowej i pierwszej okupacji sowieckiej Lwowa ${ }^{1}$. Szereg informacji i ciekawych szczegółów z życiorysu kapłana dostarczają wspomnienia, które są przedmiotem niniejszej edycji. Ich autorka Maria Kapri urodziła się 2 VI 1894 r. w Todirești k. Suczawy na Bukowinie w rodzinie ormiańskiej barona Andrzeja Kapri (zm. 1906) i Eufrozyny Bendella (zm. 1902). Po śmierci rodziców zamieszkała wraz z młodszą siostrą Heleną u krewnych. Ukończyła szkołę żeńską prowadzoną przez Zgromadzenie Sióstr Niepokalanego Poczęcia NMP (niepokalanki) w Jarosławiu i Jazłowcu. Edukację uwieńczyła maturą, którą zdała we Lwowie w 1914 r. W 1916 r. wstąpiła do niepokalanek i przyjęła imię Fidea; w 1923 r. złożyła śluby wieczyste. W zgromadzeniu pracowała jako nauczycielka języka niemieckiego, w 1933 r. została mianowana przełożoną klasztoru w Jarosławiu. W skutek konfliktu z matką generalną Zenoną Dobrowolską w 1934 r. dobrowolnie opuściła zgromadzenie i podjęła pracę sekretarki w kancelarii abp. Józefa Teodorowicza. Po śmierci hierarchy uchroniła od zniszczenia jego rękopisy i pamiątki wywożąc je w 1945 r. z zajętego przez Sowietów Lwowa do Polski. Po wojnie była nauczycielką języków obcych w Kamienicy Polskiej k. Częstochowy i w Opolu. W latach 1952-1960 prowadziła lektoraty języków: niemieckiego, francuskiego i włoskiego w Wyższym Seminarium Duchownym Diecezji Opolskiej w Nysie. W tym czasie była inwigilowana przez Służbę Bezpieczeństwa. W 1961 r. wytoczono jej dwa procesy, w których została oskarżona o propagandę przeciwko wła-

\footnotetext{
1 Archiwum Abpa Eugeniusza Baziaka w Krakowie (dalej: AAEB), b.sygn., H. Staudt, Ks. Adam Bogdanowicz realizator wskazań liturgicznych Piusa X, Kraków 1975, mps; Archiwum Wydziału Teologicznego Uniwersytetu Opolskiego, sygn. 14/89/2009, P. Skupień, Adam Bogdanowicz (1898-1941) - kapłan, działacz narodowy, męczennik, Opole 2009, mps; L. Gr z e b i e ń, Bogdanowicz Adam, [w:] Słownik polskich teologów katolickich 1918-1981, t. 5, red. L. G r z e b i e ń, Warszawa 1983, s. 147-148; J. W ę g i e r s k i, Lwów pod okupacja sowiecką 1939-1941, Warszawa 1991, s. 359; R. D z w o n k o w s k i, Leksykon duchowieństwa polskiego represjonowanego $w$ ZSRS 1939-1988, Lublin 2003, s. 126-128; T. Z a l e s k i, Stownik biograficzny duchownych ormiańskokatolickich oraz duchownych rzymskokatolickich pochodzenia ormiańskiego w Polsce w latach 1750-2000, Kraków 2001, s. 37-38; T. K r z y ż o w s k i, Archidiecezja lwowska obrządku ormiańskokatolickiego w latach 1902-1938, Kraków 2020, s. 48, 50, 52, 67, 88-89, 122-123, 158, 172-173, 176, 183-184, 188, 201-202, 204, $221,280,300,327-328,340,349,351-352,354,368,370-373,408,421,424,432$, $444,451,457,459,463,484,541,569,576,578-579,581$.
} 
dzy komunistycznej, przechowywanie nielegalnej literatury oraz rozpowszechnianie nieprawdziwych informacji mogących zaszkodzić państwu polskiemu. $\mathrm{Z}$ powodu braku dowodów procesy umorzono w tym samym roku. Maria Kapri zajmowała się również tłumaczeniami z kilku języków obcych dokumentów kościelnych dla abp. Alfonsa Nossola oraz udzielała korepetycji. Zmarła 26 V 1985 r. w Opolu; została pochowana na cmentarzu w dzielnicy Półwieś. Uroczystościom pogrzebowym przewodniczył abp Alfons Nossol wraz z licznym duchowieństwem² .

W 1906 r. podczas pobytu u rodziny Bohdanowiczów w Orzechlibach Maria Kapri poznała kilka lat młodszego Adama Bogdanowicza. Rok później w okresie wakacji spotkali się po raz kolejny i przypuszczalnie wtedy nawiązała się między nimi trwająca wiele lat przyjaźń. Oboje wychowali się w rodzinach ziemiańskich pochodzenia ormiańskiego, odebrali staranne wykształcenie oraz podjęli realizację powołania do służby w Kościele. Reprezentowali podobny światopogląd i wartości religijno-moralne. Wymieniali poglądy na temat szeroko pojętego życia religijnego, pracy zawodowej, aktualnych wyzwań i trudności. Doskonale się rozumieli i wspierali. Bogdanowicz zwierzał się jej ze swoich rozterek i przeżyć duchowych oraz stanów emocjonalnych. O silnej więzi autorki z bohaterem wspomnień świadczy fakt, że po upływie kilku dziesięcioleci przytacza precyzyjne dane z jego życia, wspólnych spotkań i rozmów. Widywali się raczej rzadko, ale utrzymywali stały kontakt korespondencyjny. Sytuacja zmieniła się w roku 1934, kiedy Maria Kapri zamieszkała na stałe we Lwowie i rozpoczęła pracę w Kurii ormiańskiej.

Wspomnienia rozpoczynają się od wstępu skomponowanego w formie inwokacji do ks. Adama Bogdanowicza, w której autorka wyjaśnia cel ich spisania. Chce uchronić od zapomnienia jego osobę i dokonania oraz zachować je dla potomnych. Następnie w kolejności chronologicznej przywołuje ważniejsze wydarzenia z życia i działalności kapłana, uzupełnia je swoimi komentarzami oraz wzbogaca cytatami z listów

\footnotetext{
${ }^{2}$ Zbiory Autora w Krakowie, (dalej: ZAK) b.sygn. Materiały zebrane przez Magdalenę Bernacką i Dariusza Łazarskiego podczas kwerendy w 2015 r.; ZAK, List s. Janiny Martynuskiej CSIC do autora, Szymanów 28 I 2019; Jazłowiec, Jazłowiec 1938, s. 198; Nekrolog prof. Marii Kapri, „Tygodnik Powszechny”, 1985, nr 25, s. 2; J. K a r a, J. P od st a w k a, Stownik biograficzny moderatorów i profesorów, [w:] Wyższe Seminarium Duchowne w Nysie-Opolu 1949-1999. Księga Jubileuszowa, red. K. D o l a, J. W a 1 o s z e k, Opole 2000, s. 107.
} 
pisanych do niej przez ks. Bogdanowicza. Posiłkowanie się korespondencją jest cennym walorem wspomnień, gdyż zamieszczone fragmenty pozwalają na zapoznanie się z jego autentycznymi wypowiedziami. Wspomnienia mają charakter osobistej relacji, widać w nich fascynację osobą i osiągnięciami ks. Bogdanowicza, którego autorka darzyła wielką atencją. Źródło ukazuje go jako człowieka, który w życiu miał do spełnienia misję, dynamicznego, pracowitego, oddanego Kościołowi i ludziom, podejmującego ochoczo wyzwania, pełnego zapału, planów i chęci do działania. Autorka nie unika jednak tematów trudnych i kontrowersyjnych. Wspomina o jego słabościach i zmaganiach; problemach natury zdrowotnej z jednej strony, $\mathrm{z}$ drugiej o wahaniach i rozdarciu pomiędzy dwoma interesującymi go biegunami aktywności: naukowej i duszpasterskiej. Przykrym doświadczeniem było dla niego niezrozumienie, zwłaszcza przez duchownych, jego nowatorskich metod duszpasterstwa. Przeżywał także chwile rozczarowania wynikającego z odmiennego niż władze archidiecezji zdania, co do koncepcji i charakteru podejmowanej przez niego aktywności. Trudy i przeciwności starał się znosić z pokorą i optymizmem.

Autorka pomija niemal zupełnie działalność konspiracyjną ks. Bogdanowicza w okresie pierwszej okupacji sowieckiej Lwowa. Przypuszczalnie nie posiadała na ten temat bliższych informacji, dlatego dane te uzupełniono podczas prac edytorskich. Podane przez nią informacje o wyroku śmierci są błędne - oparte na poszlakach i domysłach, gdyż

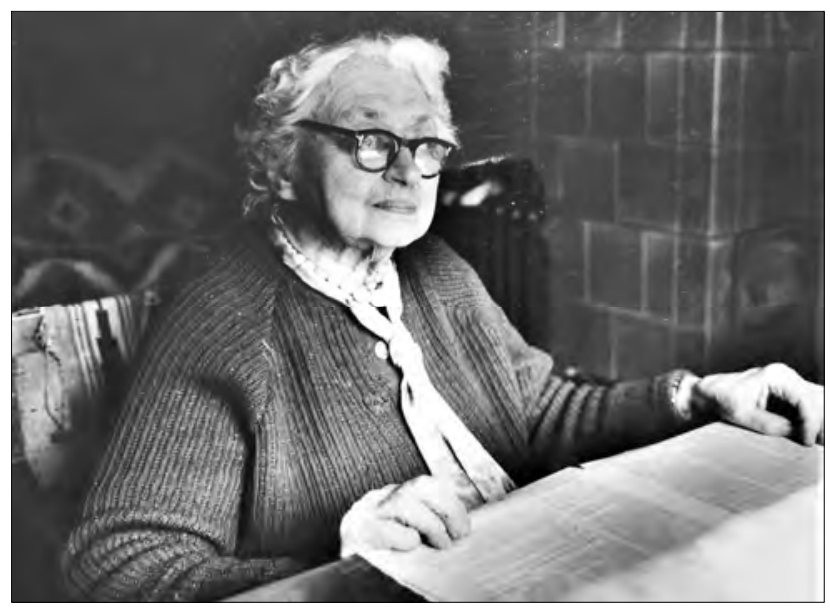

1. Maria Kapri w swoim mieszkaniu w Opolu, lata 70. XX w. 
dokumenty procesowe działaczy podziemia niepodległościowego zostały odtajnione i udostępnione badaczom dopiero po upadku Związku Sowieckiego. Trudny do odtworzenia z uwagi na rozbieżność informacji opis wydarzeń z ostatnich dni okupacji sowieckiej i okoliczności śmierci ks. Bogdanowicza (24 VI 1941) podane przez autorkę są wiarygodne i tożsame $\mathrm{z}$ relacjami innych świadków. We wspomnieniach występują drobne nieścisłości i błędy, które skorygowano podając je w poprawnej wersji. Reasumując trzeba stwierdzić, że opublikowane źródło posiada dużą wartość merytoryczną.

Data spisania wspomnień nie jest znana, choć z całą pewnością miało to miejsce kilka lat przed śmiercią autorki. Wiadomo, że Maria Kapri była poinformowana o inicjatywie zbierania relacji i materiałów źródłowych na temat ks. Bogdanowicza przez Helenę Mycielską i związaną z nią grupę kobiet, byłych wychowanek kapłana. W 1984 r. autorka przekazała wspomnianym osobom maszynopis wspomnień. Jadwiga Knaus i Helena Mycielska zapoznawszy się z jego treścią, chciały skonsultować niektóre fragmenty i dokonać za zgodą autorki poprawek i uzupełnień. W tym celu 4 V 1985 r. udała się do Opola Anna Sędziwy, która spotkała się z autorką. Maria Kapri była w tym czasie chora i zbyt słaba, aby dokonać jakiejkolwiek korekty, dlatego podpisała maszynopis $\mathrm{w}$ jego pierwotnej formie stwierdzając tym samym jego autentyczność ${ }^{3}$.

Publikowane niżej wspomnienia przechowywane są w Archiwum Diecezji Opolskiej w Opolu. Jest to maszynopis autoryzowany formatu A4 o objętości 34 kart. Podczas edycji zachowano oryginalny styl autorki, uwspółcześniono jedynie archaizmy podając je w obecnym brzmieniu oraz skróty rozwinięto w nawiasach kwadratowych. Ponadto tekst wzbogacono o wyjaśnienia i uzupełnienia podane w przypisach. Literami alfabetu łacińskiego podano informacje natury formalnej; przypisy oznaczone symbolem,$*$ " pochodzą od autorki ${ }^{4}$. Uzupełnieniem prezentowanej edycji źródłowej jest kilka fotografii archiwalnych przedstawiających ks. Bogdanowicza i jego rodzinę.

\footnotetext{
3 Archiwum Diecezji Opolskiej (dalej: ADO), b.sygn., Kopia listu Jadwigi Knaus do Marii Kapri, Kraków 3 V 1985; ADO, Oświadczenie Anny Sędziwy, Kraków 6 V 1985.

4 Tekst źródłowy opracowano według instrukcji wydawniczej: I. I h n a t o w i c z, Projekt instrukcji wydawniczej dla źródet historycznych XIX i początku XX wieku, „Studia Źródłoznawcze”, t. 7, 1962, s. 99-124
} 


\section{Edycja źródła}

\section{Drogi Adasiu,}

Przejęta gorącym pragnieniem wydarcia świetlanej Twej postaci zapomnieniu, pragnę - sama będąc już u schyłku życia - poświęcić słowa tego wspomnienia Tobie i pamięci naszych częstych, nieprzerwanych prawie kontaktów. Ciągnęły się one niby perły nanizane na nici naszego żywota poprzez lata naszego dzieciństwa częściowo „sielsko anielskiego”, choć nie wolnego od ciężkich przejść, skoro ja mając ledwo 11 lat weszłam w to życie jako całkowita sierota, Ty zaś już w 9-tym roku straciłeś ojca - i dalej poprzez naszą młodość rzeczywiście „górną i chmurną”, kiedy to sięgaliśmy po najwyższe ideały ziemskiego bytowania - a wreszcie i poprzez to, co nazwać by można raczej „wiekiem męskim - wiekiem klęski”, kiedy Ty rokujący najpiękniejsze nadzieje i będąc w pełni sił, na skutek straszliwych działań wojennych, złożyłeś Bogu w ofierze to życie swoje, od któregośmy wszyscy tyle jeszcze oczekiwali.

Pragnę opisać tu to wszystko, czego byłam świadkiem od lat najmłodszych - to coś Ty mi powierzył osobiście, opowiadając własne przeżycia, zamierzenia na przyszłość, przeszkody, na jakie natrafiałeś, co skreśliłeś w długiej, blisko 20 lat trwającej korespondencji, w końcu to cośmy razem przeżywali u boku naszego wielkiego „Eryspochana”, i świętego Arcypasterza śp. Ks. Arcybiskupa Teodorowicza ${ }^{6}$ kiedyś Ty,

${ }^{5}$ Eryspochan (orm. Łpłguhnuuud) - dosłownie: zastępca kapłana. W okresie staropolskim we Lwowie było dwóch eryspochanów, którzy stali na czele kolegium prowizorów majątku kościelnego. Tutaj określenie użyte dla podkreślenia roli abp. Teodorowicza jako duchowego przywódcy Ormian polskich.

${ }^{6}$ Józef Teodorowicz (1864-1938) - urodzony w Żywaczowie na Pokuciu w rodzinie ormiańskiej, w 1882 r. ukończył gimnazjum w Stanisławowie i rozpoczął studia teologiczne oraz formację ascetyczną w seminarium duchownym we Lwowie jako alumn archidiecezji ormiańskokatolickiej. W 1887 r. przyjął święcenia kapłańskie i pracował duszpastersko jako wikariusz we Lwowie i w Stanisławowie, w 1890 r. został administratorem, a po kilku latach proboszczem parafii ormiańskiej w Brzeżanach. W 1897 r. otrzymał nominację na kanonika gremialnego kapituły ormiańskiej we Lwowie. Rozpoczął działalność społeczną i pisarską, był m.in. współzałożycielem dzienników „Ruch Katolicki” i „Przedświt”. W 1901 r. wybrany przez duchowieństwo arcybiskupem ormiańskim; 2 II 1902 r. otrzymał sakrę biskupią i odbył ingres do katedry lwowskiej. Należał do Izby Panów w Wiedniu (1902-1918), Sejmu Krajowego we Lwowie (1902-1914), Konferencji Episkopatu Austrii (1902-1918). W okresie międzywojennym poseł do Sejmu Ustawodawczego (1919-1922) i senator RP (1922-1923). Energicznie pracował także na forum episkopatu Polski wchodząc w skład komitetu 
jako kanonik kapituły ormiańskiej ${ }^{7}$, jako redaktor ormiańskiego pisma religijnego „Gregoriana" ${ }^{8}$ był nieomal że codziennym gościem w pałacu arcybiskupim i w Sekretariacie jego, w którym miałam szczęście przepracować kilka niezapomnianych i najpiękniejszych lat mojego życia.

Po tak boleśnie odczutym zgonie naszego Arcypasterza (†4 XII 1938 r.), po wybuchu drugiej wojny światowej (1 IX [19]39 r.), kiedy wahały się jeszcze losy stolicy arcybiskupstwa ormiańskiego, a większość Ormian w Tobie widziała następcę na tejże stolicy ${ }^{9}$, Tyś już tylko kilka krótkich miesięcy pozostał na wolności. Zabrany przez wysłanników NKWD ${ }^{10}$

biskupów oraz kilku komisji episkopatu. Ideowo związany z obozem Narodowej Demokracji. W 1911 i 1928 r. uczestniczył w obradach Synodu Episkopatu Ormiańskiego w Rzymie. Abp Teodorowicz był cenionym mówcą, kaznodzieją oraz autorem książek o charakterze religijnym, w tym kilkutomowej edycji o życiu Chrystusa. Otrzymał doktorat honoris causa Uniwersytetu Lwowskiego Franciszkańskiego we Lwowie (1912) i Order Polonia Restituta (1924). Zmarł we Lwowie 4 XII 1938 r., został pochowany na Cmentarzu Orląt. W okresie sowieckim w obawie przed profanacją doczesnych prochów arcybiskupa przeniesiono je do prywatnego grobowca na Cmentarzu Łyczakowskim. W 2011 r. po wieloletnich staraniach diaspory ormiańskiej w Polsce doczesne szczątki hierarchy złożono ponownie na Cmentarzu Obrońców Lwowa. T. K r z y ż o w s k i, Kresowy głos sumienia. Arcybiskup Józef Teodorowicz (1864-1938), „Biuletyn IPN”, 2019, nr 10, s. 11-22.

${ }^{7}$ Kapituła Katedralna obrządku ormiańskokatolickiego we Lwowie - erygowana w 1803 r., składała się z 4 kanonii gremialnych i 4 honorowych. W 1896 r. otrzymała statut zatwierdzony przez Stolicę Apostolską. T. Krzyżowski, Archidiecezja lwowska obrzadku ormiańskokatolickiego w latach 1902-1938, Kraków 2020, s. 190-191.

8 „Gregoriana” - dwumiesięcznik wydawany we Lwowie w latach 1935-1938 przez władze archidiecezji ormiańskiej; łącznie ukazały się 22 zeszyty czasopisma. Redaktorem naczelnym był ks. Adam Bogdanowicz. Na łamach periodyku publikowano artykuły i recenzje książek z zakresu teologii, biblistyki, nauk społecznych, żywotów świętych oraz dorobek literacki i kaznodziejski abp. Józefa Teodorowicza. Tamże, s. 457-459.

9 Aluzja do wyboru następny abp. Józefa Teodorowicza na stolicę arcybiskupów ormiańskich we Lwowie. Elekcja przeprowadzona 2 I 1939 r. przez duchowieństwo ormiańskie wyłoniła trzech kandydatów, którzy zostali przedstawieni Stolicy Apostolskiej. Liderem był ks. Dionizy Kajetanowicz, który otrzymał 11 głosów. Ks. Bogdanowicz we wspomnianym głosowaniu otrzymał 3 głosy otrzymując piątą lokatę ex aequo z ks. Bohosem Kirmizjanem i ks. Wiktorem Kwapińskim. Być może niektóre środowiska ormiańskie doceniając walory duchowe i zdolności ks. Bogdanowicza upatrywały w nim przyszłego arcybiskupa, ale wynik przeprowadzonego głosowania jak również decyzje Watykanu nie pozostawiały złudzeń i nie dawał szans na nominację dla ks. Bogdanowicza. T. K r z y ż o w s k i, Kulisy nominacji następcy ormiańskokatolickiego arcybiskupa Lwowa Józefa Teodorowicza, „Lehahayer. Czasopismo Poświęcone Dziejom Ormian Polskich”, 2018, nr 5, s. 254.

${ }^{10}$ NKWD - ros. Narodnyj komissariat wnutriennich dieł (Ludowy Komisariat Spraw Wewnętrznych) - centralny organ władzy w Rosji Sowieckiej i Związku Sowieckim 
w nocy z 1. na 2. IV 1940 r., Tyś już na zawsze zginął nam z oczu. Dalsze losy Twoje męczeńskie i koniec Twojego życia znane nam są już tylko z relacji, częściowo sprzecznych ze sobą, świadków rzekomo naocznych, z których wynika tylko jedna pewność: żeś zginął - żeś życie swoje, rokujące tak wielkie i piękne nadzieje złożył Bogu w ofierze w lochach więzienia, do którego Cię porwano.

Może mi Bóg pozwoli uchylić choć mały rąbek Twojej tajemnicy, tej „tajemnicy królewskiej” którąś uniósł ze sobą w zaświaty. A jeśli nie uda mi się tego uczynić, to żywię mocną nadzieję, że dokona tego, w mierze przez Boga mu zakreślonej ów kapłan, sługa Boży, w którego sercu Bóg złożył pragnienie opisania Twojego życia dla przekazania go potomności ${ }^{11}$.

Adam Rożko-Bogdanowicz ${ }^{12}$ urodził się dnia 12 VII 1898 r. w Dolinianach $^{13}$ niedaleko Lwowa, w majątku swojego ojca Stanisława ${ }^{14}$ jako pierworodny i jedyny syn jego i Wandy z domu Oroszeny Bohdanowiczówny ${ }^{15}$.

działający w latach 1917-1946, odpowiednik ministerstwa. Urząd sprawował kontrolę nad milicją i innymi służbami mundurowymi, wywiadem, kontrwywiadem, siecią obozów pracy oraz nadzorował lokalne instytucje rządowe. NKWD odegrało znaczącą rolę w budowaniu reżimu stalinowskiego oraz walki z przeciwnikami systemu. $N K W D$, Narodnyj komissariat wnutriennich diet, Ludowy Komisariat Spraw Wewnętrznych, [w:] Wielka Encyklopedia PWN, t. 19, red. J. W o j n o w s k i, Warszawa 2003, s. 91.

${ }^{11}$ Aluzja do osoby zainteresowanej napisaniem biografii ks. Bogdanowicza. Prawdopodobnie chodzi o ks. Henryka Staudta z archidiecezji krakowskiej, który w latach 70. $\mathrm{XX}$ w. zbierał materiały na temat ks. Bogdanowicza i korespondował w tej sprawie z Marią Kapri. Efektem jego kwerendy jest praca licencjacka: AAEB w przypadku prac magisterskich należy podawać archiwum uczelni, gdzie deponowane są oficjalne wersje prac, b.sygn., H. Staudt, Ks. Adam Bogdanowicz realizator wskazań liturgicznych Piusa X, Kraków 1975, mps.

${ }^{12}$ Bardziej powszechny zapis tego nazwiska występował w formie: „Roszko-Bogdanowicz”, „Rosco-Bogdanowicz” lub „de Rosco-Bogdanowicz”. Ks. Bogdanowicz posługiwał się jedynie formą „Bogdanowicz”.

13 Doliniany - wieś na zachód od Lwowa, należała do powiatu Gródek Jagielloński, obecnie na Ukrainie

14 Stanisław Bogdanowicz (1867-1907), ziemianin pochodzenia ormiańskiego, ur. 8 VII 1867 r. w Kossowie w rodzinie Michała Kajetana i Józefy Warteresiewicz. Zm. 30 VII 1907 r. Pochowany został na Cmentarzu Lyczakowskim we Lwowie. Stanisław Bogdanowicz (1867-1907), www.wiki.ormianie.pl [dostęp: 14.05.2020].

15 Wanda Bogdanowicz (1869-1949), ur. w Oroszowcach k. Kocmania (Bukowina) w rodzinie ormiańskiej Grzegorza de Oroszeny Bohdanowicza i Rozalii z Zadurowiczów. Zawarła związek małżeński ze Stanisławem Bogdanowiczem. Mieszkała we Lwowie, 
Od najmłodszych lat otrzymał najstaranniejsze, rdzennie katolickie wychowanie będąc dzieckiem niezwykle uzdolnionym, bystrym i nad wiek rozwiniętym.

Po ciężkim zapadnięciu na zdrowiu ojca jego Stanisława, po utracie majątku, matka małego Adasia schroniła się wraz z nim do swojej matki Rozalii z Zadurowiczów Bohdanowiczowej ${ }^{16}$, wdowie po Grzegorzu Bohdanowiczu $^{17}$, która zamieszkiwała majątek rodzinny Oszechliby

gdzie angażowała się w działalność społeczno-religijną, m.in. w Kongregacji Ziemianek pw. Matki Boskiej Kochawińskiej, w której w latach 30. XX w. pełniła funkcję prezeski. Aktywnie włączała się też w publikowanie recenzji literatury religijnej na łamach czasopisma „Gregoriana”. Na wniosek abp. J. Teodorowicza otrzymała w 1937 r. od Stolicy Apostolskiej odznaczenie Pro Ecclesia et Pontifice. Po II wojnie światowej zamieszkała w Krakowie, gdzie zmarła 16 VIII 1949 r. i pochowana została na Cmentarzu Rakowickim. T. K r z y ż o w s k i, Archidiecezja lwowska obrzq̨dku ormiańskokatolickiego, s. 47, 578; Wanda Bogdanowicz (1869-1949), www.wiki.ormianie.pl [dostęp: 14.05.2020].

16 Rozalia de Oroszeny Bohdanowicz (1844-1932), ur. w Rożnowie k. Kosowa w rodzinie ormiańskiej Kajetana Zadurowicza i Marii z Passakasów. W 1863 r. zawarła związek małżeński z Grzegorzem Bohdanowiczem, z którym miała czworo dzieci: Kazimierza (1866-1937), Stanisława (1868-1938), Wandę (1869-1949), Tadeusza (1880-1961). Mieszkała w Oszechlibach, gdzie z mężem prowadziła majątek ziemski. F. Wasyl, Ormianie w świetle zapowiedzi przedmatzeńskich rodzimej parafii w Kutach. Edycja źródła, cz. 1: lata 1860-1914, „Krakowskie Pismo Kresowe”, 2016, nr 8, s. 108. Rozalia de Oroszeny Bohdanowicz (1844-1932), www.wiki.ormianie.pl [dostęp: 14.05.2020].

17 Grzegorz de Oroszeny Bohdanowicz (1834-1901), syn Stefana i Justyny z Antoniewiczów, po których odziedziczył wieś Oszechliby. Należał do elity ziemiaństwa ormiańskiego. Wspierał własnym sumptem i autorytetem inicjatywy społeczne, polityczne i patriotyczne oraz angażował się w zachowanie kultury polskiej na Bukowinie. Sprowadził do Czerniowiec Towarzystwo Kredytowe Galicyjskie oraz Towarzystwo Wzajemnych Ubezpieczeń, przyczynił się do powstania w 1883 r. „Gazety Polskiej” zapewniając jej zaplecze finansowe, wspierał budowę kościoła ormiańskokatolickiego w Czerniowcach. Był zręcznym i skutecznym politykiem, należał do Stronnictwa Ormiańsko-polskiego i kierował jego pracami. Dzięki temu reprezentujący wielką własność ziemską Polacy i Ormianie z Bukowiny zwiększyli swoje wpływy w Sejmie Krajowym i Radzie Państwa w Wiedniu. Wiele organizacji polskich przyjęło go w poczet członków honorowych; jego aktywność doceniły również władze austriackie przyznając mu komandorię Orderu Franciszka Józefa. Zmarł 19 X 1901 r. w Oszechlibach. F. P o h o r e c k i, Bohdanowicz Grzegorz, [w:] Polski Słownik Biograficzny (dalej PSB), t. 2, red. W. K o n o p c z y ń s k i, Kraków 1936, s. 221; A. A. Z i ę b a, Grzegorz de Oroszeny Bohdanowicz, [w:] Portrety Ormian Polskich, [kalendarz na 2017 r. wydany przez Fundację Kultury i Dziedzictwa Ormian Polskich w Warszawie]. 


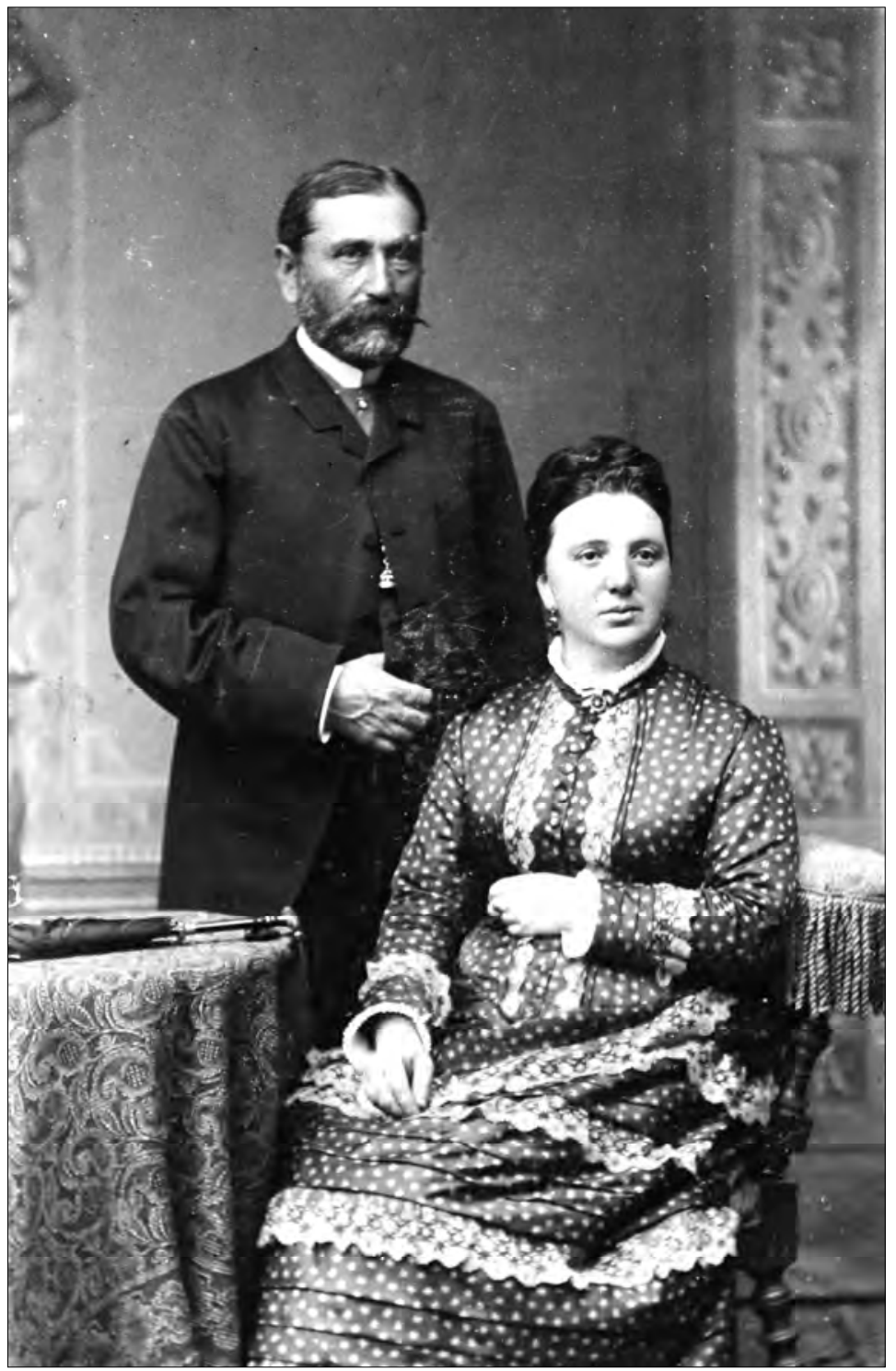

2. Grzegorz i Rozalia de Oroszeny Bohdanowicz 
na Bukowinie ${ }^{18}$. Tam też zaczął Adaś, po skończonym szóstym roku życia, pobierać nauki, początkowo u sprowadzonych na ten cel do domu nauczycielek prywatnych, z których się nam szczególnie upamiętniła urocza panna Edzia Przyłuska ${ }^{19}$, wychowanka Niepokalanek. Ona to pięknie pokierowała pierwszymi krokami szkolnymi Adasia. Pamiętam, że pierwsze moje osobiste zetknięcie z Adasiem miało miejsce w r. 1906 [w] pierwszych dni[ach] września, kiedy jadąc do Niepokalanek w Jarosławiu $^{20}$ celem dalszego pobierania tam nauki wstąpiłam wraz ze Siostrą $^{21}$ moją do Oszechlib. Adaś zaczynał wtedy 3. klasę podstawową. W rok później już przez całe wakacje 1907 r. spędzone w Oszechlibach stykaliśmy się z Adasiem na codziennych zabawach. Wtedy też przypadła śmierć jego ojca we Lwowie, w domu babki jego p[ani] Bogdanowiczowej $^{22}$, która pielęgnując syna do ostatka w ciężkiej i nieuleczalnej chorobie, doczekała się tej pociechy - będąc sama bardzo pobożna, że syn jej pojednał się z Bogiem. Pamiętam z owych czasów ten szczegól, że Ks. Arcybiskup Teodorowicz, przebywający wówczas na kuracji w Marienbadzie ${ }^{23}$, zjechał nagle do Lwowa, bo umierający p[an] Stanisław Bogdanowicz zapragnął u niego tylko odbyć ostatnią swą spowiedź.

18 Oszechliby - wieś na Pokuciu na południowy-wschód od Śniatynia, obecnie na Ukrainie.

19 Edwarda Załuska z d. Przyłuska (1884-1966), ur. w Dąbiu, absolwentka szkoły niepokalanek w Jazłowcu, pracowała jako nauczycielka. W 1910 r. wyszła za mąż za Jana Załuskę (1873-1941) - doktora medycyny i polityka związanego z Obozem Narodowym, z którym miała dwójkę dzieci. Mieszkała w Warszawie, pochowana na Powązkach. S. Ł o z a, Czy wiesz kto to jest?, Warszawa, 1938, s. 833; Jazłowiec, s. 196. 20 Jarosław - miasto w Galicji położone nad Sanem, obecnie miasto powiatowe w woj. podkarpackim.

21 Helena Kapri (1895-1977), absolwentka szkoły niepokalanek w Jarosławiu i Jazłowcu, nauczycielka muzyki. Wyszła za mąż za Franciszka Kunza, przedsiębiorcę, właściciela fabryki tytoniu. W czasie II wojny światowej i w okresie powojennym mieszkała w Krakowie; pochowana na Cmentarzu Rakowickim w Krakowie. ZAK, b.sygn., Materiały zebrane przez Magdalenę Bernacką i Dariusza Lazarskiego podczas kwerendy w 2015 r.; Jazłowiec, s. 198.

22 Józefa Bogdanowicz (1844-?), ur. w rodzinie ormiańskiej Ignacego Warteresiewicza i Kajetany z Bohdanowiczów, w 1864 r. zawarła związek małżeński z Michałem Bogdanowiczem, z którym miała pięcioro dzieci. Drzewo genealogiczne RoszkoBogdanowiczów, http://www.skarbnica.ormianie.pl [dostęp: 16.09.2020].

${ }^{23}$ Właściwie: Mariańskie Łaźnie (niem. Marienbad) - znana miejscowość turystycznowypoczynkowa w Czechach w kraju karlowarskim, wówczas na terenie Austro-Węgier. 
Ponieważ śmierć ta, choć spodziewana od dawna, zaskoczyła rodzinę nagle, a na wsi niepodobna było zdobyć jakąkolwiek żałobę, więc dla Adasia sporządzono naprędce czarne ubranko z mojej sukienki pozostałej z żałoby po Ojcu moim zmarłym w 1906 r. Z pogrzebu powrócił Adaś $\mathrm{b}$ [ardzo] smutny, jakiś dziwnie zamyślony i przygnębiony.

Gdy Adaś skończył 10 lat pożegnała go tak ukochana przez niego dotychczasowa nauczycielka panna Edzia, a miejsce jej zajął preceptor pan August Paszkudzki²4, który objął nauczanie gimnazjalnych przedmiotów, wedle programów szkół austriackich, którym podlegało ówczesne nauczanie.

W którymś z następnych lat (był to bodaj r. 1910) oddała matka Adasia do nowo utworzonego w Kongresówce ${ }^{25}$, w Komorowie ${ }^{26}$ niedaleko Warszawy, Zakładu ${ }^{27}$ Księdza Gralewskiego ${ }^{28}$, w którym ten ostatni

${ }^{24}$ August Paszkudzki (ur. 1888-?), ur. w Tarnopolu, dr filozofii, nauczyciel w gimnazjach lwowskich, uczył historii, geografii oraz języków: polskiego i niemieckiego. Opublikował komentarze konstytucji z 1921 r. i 1935 r. Działacz oświatowy, społeczny i polityczny. A. W e r n e r, Ocalenie z innego miejsca, Sanok 2017, s. 40-41.

${ }^{25}$ Kongresówka - potoczna nazwa Królestwa Polskiego, państwa zależnego od Cesarstwa Rosyjskiego, utworzonego w 1815 r. decyzją kongresu wiedeńskiego. Istniało do 1918 r.

${ }^{26}$ Błąd autorki, zakład wychowawczy ks. Gralewskiego mieścił się w Starej Wsi na południowy-wschód od Warszawy w powiecie Mińsk Mazowiecki, a w roku szkolnym 1908/1909 w Szymanowie.

${ }^{27}$ Polskie Ognisko Wychowawcze - szkoła średnia z internatem istniejąca w latach 1907-1914, założona przez ks. Jana Gralewskiego, Witolda Czartoryskiego i Kazimierza Lutosławskiego w Starej Wsi k. Otwocka w zaborze rosyjskim; mająca swoje oddziały także na terenie Galicji. Program nauczania i zasady wychowawcze oparto na nowych trendach obecnych w pedagogice i szkolnictwie Europy Zachodniej. W wychowaniu zwracano uwagę na ukształtowanie prawego charakteru, dojrzałych postaw obywatelskich, koleżeństwa, szacunku do innych, patriotyzmu, rozwoju różnych umiejętności przydatnych w dorosłym życiu. W procesie nauczania nacisk kładziono na wypracowanie umiejętności swobodnej obserwacji i wyciągania wniosków oraz tłumaczenia zachodzących zjawisk, a nie przyswajania wiedzy bez zrozumienia. Z podręczników korzystano rzadko; uczono m.in. przyrody, logiki, filozofii, geografii, fizyki, chemii, literatury i sztuki, muzyki, języka polskiego, języków obcych (obowiązkowo angielskiego i innych do wyboru), historii Polski i polskiej literatury. Dużą wagę przywiązywano do ćwiczeń fizycznych i sportu, organizowano szkolne wycieczki. Uczniowie mieli do dyspozycji pracownie naukowe, bibliotekę, warsztat stolarski i ślusarski, wydawali prasę szkolną, działali w kołach naukowych. Polskie Ogniska Wychowawcze Wiejskie. Zasady i środki. Program pierwszego polskiego Ogniska Wychowawczego Wiejskiego dla chłopców, Lwów 1906, s. 1-16; H. C h o d y n i c k i, Polskie Ognisko Wychowawcze Wiejskie (1906-1914), [w:] Eksperymenty pedagogiczne w Polsce w latach 1900-1939, red. B. N a w r o c z y ń s k i, Wrocław 1963, s. 33-51. 
podjąć miał zgoła nowe, dotychczas nieznane metody wychowania i kształcenia młodzieży męskiej. Sama Matka odwiozła tam Adasia. On jednak w zakładzie tym niezbyt długo zagrzał miejsca. Tęsknił okropnie za domem, za matką, a modny eksperyment już po roku spalił na panewce, po prostu nie udał się. Adaś w dalszym ciągu kształcił się w domu aż do roku 1911, kiedy zdał do III. kl[asy] gimnazjalnej we Lwowie i tamże oddany został na stancję do pani Zofii z Firlejów Teodorowiczowej $^{29}$, mieszkającej przy ul. św. Zofii. Tam się też zetknęłam z nim kiedy był uczniem V. kl[asy] gimnazjalnej, ja zaś przyjechałam do Lwowa na zdawanie matury. Przybiegał do nas tj. do mojej siostry i do mnie raz po raz do pobliskiego pensjonatu ,Zacisze"30 gdzieśmy zajeżdżały $\mathrm{z}_{\text {Jazłowca }}{ }^{31}$ na pojedyncze etapy naszej podówczas prywatnie zdawanej,

28 Jan Gralewski (1868-1924) - kapłan archidiecezji warszawskiej, święcenia kapłańskie przyjął w 1891 r. Był wikariuszem i katechetą w Grodzisku Mazowieckim i Warszawie, równolegle angażował się w działalność społeczną, m.in. w Towarzystwie Higienicznym i Towarzystwie Dobroczynności. Interesował się pedagogiką, w 1. 1899-1914 należał do komitetu redakcyjnego Encyklopedii Wychowawczej, był jednym z liderów Polskiej Macierzy Szkolnej, jeden z organizatorów strajku szkolnego w 1905 r. W 1. 1905-1911 należał do Stronnictwa Narodowo-Demokratycznego, z którego listy został posłem do I i II Dumy Imperium Rosyjskiego (1906-1907). W 1. 19041906 odbył podróże do Francji, Anglii i Stanów Zjednoczonych, gdzie zapoznał się z tamtejszym systemem szkolnictwa. Poznane metody wychowawcze i edukacyjne wcielił w życie w szkole średniej nazywanej Ogniskiem, którą założył w 1907 r. w Starej Wsi. Odważnie głosił swoje poglądy na temat reform w Królestwie Polskim, zwłaszcza dotyczące szkolnictwa, za co spotkały go represje, m.in. zakaz publicznych wypowiedzi i czasowe wydalenia poza granice Królestwa. Od 1908 r. związany ze Stowarzyszeniem Nauczycielstwa Polskiego, w którym pełnił funkcje kierownicze, m.in. przewodniczył Sekcji Wychowawczej i Komisji Pedagogicznej. W 1. 1916-1918 przebywał w Szwajcarii, gdzie włączył się w działalność patriotyczną Polonii. Od 1918 r. inspektor krajowy szkolnictwa powszechnego w Ministerstwie Wyznań Religijnych i Oświecenia Publicznego. W 1. 1921-1923 duszpasterz i nauczyciel w parafii Domaniewice. Zmarł w Warszawie 17 II 1924 r. S. K o n a r s k i, Gralewski Jan, [w:] PSB, t. 8, red. K. L e p s z y, Wrocław-Kraków-Warszawa 1959-1960, s. 538-540.

${ }^{29}$ Właściwie: Eugenia Teodorowicz z d. Firlej (1871-1945), w 1892 r. wyszła za mąż za Stanisława Teodorowicza (1866-1923), ormianina, urzędnika, kuzyna abp. Józefa Teodorowicza, z którym miała dwoje dzieci: Władysława i Annę. Zmarła we Lwowie, pochowana wraz z mężem na Cmentarzu Łyczakowskim. Drzewo genealogiczne Teodorowiczów, http://www.skarbnica.ormianie.pl [dostęp: 16.09.2020].

${ }^{30}$ Pensjonat ,Zacisze” mieścił się we Lwowie przy ul. Zyblikiewicza 52.

31 Jazłowiec - miejscowość w Galicji Wschodniej na południe od Buczacza, obecnie na terenie Ukrainy. W 1863 r. Marcelina Darowska założyła tam klasztor sióstr niepokalanek oraz szkołę dla dziewcząt. 
a więc b[ardzo] ciężkiej matury. Adaś przynosił nam wówczas różne potrzebne nam teksty łacińskie, w których okazał się bardzo biegłym.

Wybuchła w parę tygodni po naszej maturze pierwsza wojna światowa oddzieliła nas znów na długie miesiące od reszty rodziny. Wyjechałyśmy bowiem do Wiednia. Dopiero w początkach kwietnia 1916 r. zetknęłam się ponownie z Adasiem. Odwiedziłam go przejeżdżając przez Lwów w mieszkaniu jego przy ul. Jakuba Strzemię, gdzie wówczas był na stancji i przygotowywał się już do matury, przerabiając w tempie przyśpieszonym materiał utraconych dwóch lat nauki.

Wtedy też zwierzył mi się ze swoich, dla mnie bardzo ciekawych, przejść wojennych. Będąc wychowany w gorącym patriotyzmie, gdy tylko zasłyszał o pierwszej formacji legionów, bez chwili wahania w siedemnastym roku życia zaciągnął się do nich i wziął niedługo potem udział w bitwie czy potyczce, która miała miejsce gdzieś w pobliżu Czerniowiec (stolicy ówczesnej Bukowiny) ${ }^{32}$. Odniósłszy jak mi opowiadał - w tej bitwie ranę, zresztą wcale niegroźną, o której z uśmiechem wspominał, doznał, leżąc na polu bitwy, wewnętrznego oświecenia: Bóg dał mu poznać, że aby wybawić Polskę nie tyle potrzeba chwytać się oręża, ile raczej oddać się modlitwie, służyć Bogu przez ofiary i pracę nad duszami. I wtedy to zrodziło się w nim postanowienie wstąpienia do seminarium. Gdy wówczas rozmawiał ze mną, postanowienie to już było konkretnie powzięte - chodziło tylko o to by zdał maturę. Głęboko przejęta tą jego relacją i myślą, że zostanie kapłanem, pożegnałam go wówczas z nadzieją, że i w dalszym życiu danym nam będzie kontaktować się ze sobą.

Pierwszy list, jaki otrzymałam od niego, nosi datę 22 IV 1917 [roku] pisany był z Zakopanego [z] tzw. „Księżówki”33, gdzie jako 19-letni już kleryk, przebywał na wypoczynku. Oto wyjątek z tego listu:

„Dziwisz się zapewne, dlaczego jestem w Zakopanem. Pan Jezus chciał, żebym odbył rekolekcje, więc mi zesłał rozstrój nerwowy, który mnie zmusił spędzić tu święta. A za przewodnika duchowego dał mi Pan Jezus Siostrę Teresę od Dzieciątka Jezus i Oblicza Pańskiego $^{34}$, karmelitankę. Słusznie zauważono, że łaski spływające na

\footnotetext{
32 Księstwo Bukowiny od 1849 r. było odrębnym krajem koronnym wchodzącym w skład Cesarstwa Austriackiego.

${ }^{33}$ Ośrodek rekolekcyjno-wypoczynkowy dla kapłanów w Zakopanem działający od $1910 \mathrm{r}$.

34 Teresa od Dzieciątka Jezus (1873-1897) - ur. we Francji, w 1888 r. wstąpiła do zakonu karmelitanek bosych w Lisieux, w 1890 r. złożyła śluby zakonne. W zakonie
} 
czytających dzieje Świętych, zostały przez nich życiem miłości i zaparcia wysłużone. Siostra Teresa wielką jest zapewne świętą! Wiele, bardzo wiele zawdzięczam tej Apostołce miłości”.

W r. 1921 otrzymał ks. Adam święcenia kapłańskie z rąk Ks. Arcybiskupa Teodorowicza w Krakowie ${ }^{35}$ w kaplicy prywatnej J[ego] Eks[celencji] Metropolity ${ }^{36}$ Adama Sapiehy ${ }^{37}$. Obecnym było na tej uroczystości tylko nieliczne grono najbliższej rodziny. Ponieważ Ks. Adam nie miał jeszcze skończonych 24 lat, więc święcenia te otrzymał za dyspensą.

Następny list jego do mnie skreślony był w r[oku] 1922, kiedy to ja po ciężkich przejściach wojennych, kilkumiesięcznym internowaniu przez Ukraińców (od 26 XII 1918 do 12 VII 1919) ${ }^{38}$ - po spędzeniu kilku tygodni (od 1 VIII 1920 do 29 IX 1920) pod rządami Bolszewików $^{39}$, którzy wówczas wtargnęli na rubieże wschodnie odrodzonej Polski - zachorowałam śmiertelnie i po ciężkich krwotokach płucnych, ciągnących się przez parę tygodni, znalazłam się u wrót wieczności.

Oto treść listu ks. Bogdanowicza pisanego do mnie z Warszawy $\mathrm{p}$ [od] d[atą] 15 III $1922 \mathrm{r}$.

pełniła posługę zakrystianki i mistrzyni nowicjatu. Swoje obowiązki starała się wiernie wypełniać i dążyć do doskonałości. Szczególnie modliła się za kapłanów i misje. W 1923 beatyfikowana, w 1925 r. kanonizowana, w 1997 r. ogłoszona Doktorem Kościoła. Pozostawiła autobiografię Dzieje duszy należącą do klasyki literatury karmelitańskiej. Relikwie spoczywają w bazylice w Lisieux. S. P r a ś k i e w i c z, Teresa od Dzieciątka Jezus, [w:] Encyklopedia katolicka (dalej: EK), t. 19, red. E. Gi g i le w i c z, Lublin 2013, kol. 708-709.

35 Błąd autorki; święcenia kapłańskie ks. Bogdanowicz przyjął w 1920 r.

${ }^{36}$ W rzeczywistości Adam Sapieha był wówczas biskupem ordynariuszem, a nie arcybiskupem-metropolitą krakowskim.

37 Adam Stefan Sapieha (1867-1951) - święcenia kapłańskie przyjął w 1893 r. we Lwowie, wikariusz w Jazłowcu (1894-1895), dr prawa kanonicznego Uniwersytetu Laterańskiego w Rzymie (1896), wicerektor Seminarium Duchownego obrządku łacińskiego we Lwowie (1897-1901), kanonik Kapituły Metropolitalnej obrządku łacińskiego tamże (1902-1911), osobisty sekretarz papieża Piusa X (1906-1911), 24 XI 1911 r. mianowany ordynariuszem krakowskim, 14 XII 1925 r. arcybiskupem metropolitą, 18 II 1946 r. kreowany kardynałem, senator I kadencji wybrany z listy Chrześcijańskiego Związku Jedności Narodowej (1922-1923). P. Ni t e c ki, Biskupi Kościoła w Polsce w latach 965-1999. Słownik biograficzny, Warszawa 2000, kol. 392-393.

${ }^{38}$ Chodzi o wojnę ukraińsko-polską o Lwów i Małopolskę Wschodnią trwającą w latach 1918-1919.

${ }^{39}$ Chodzi o wojnę polsko-bolszewicką w latach 1919-1920. 


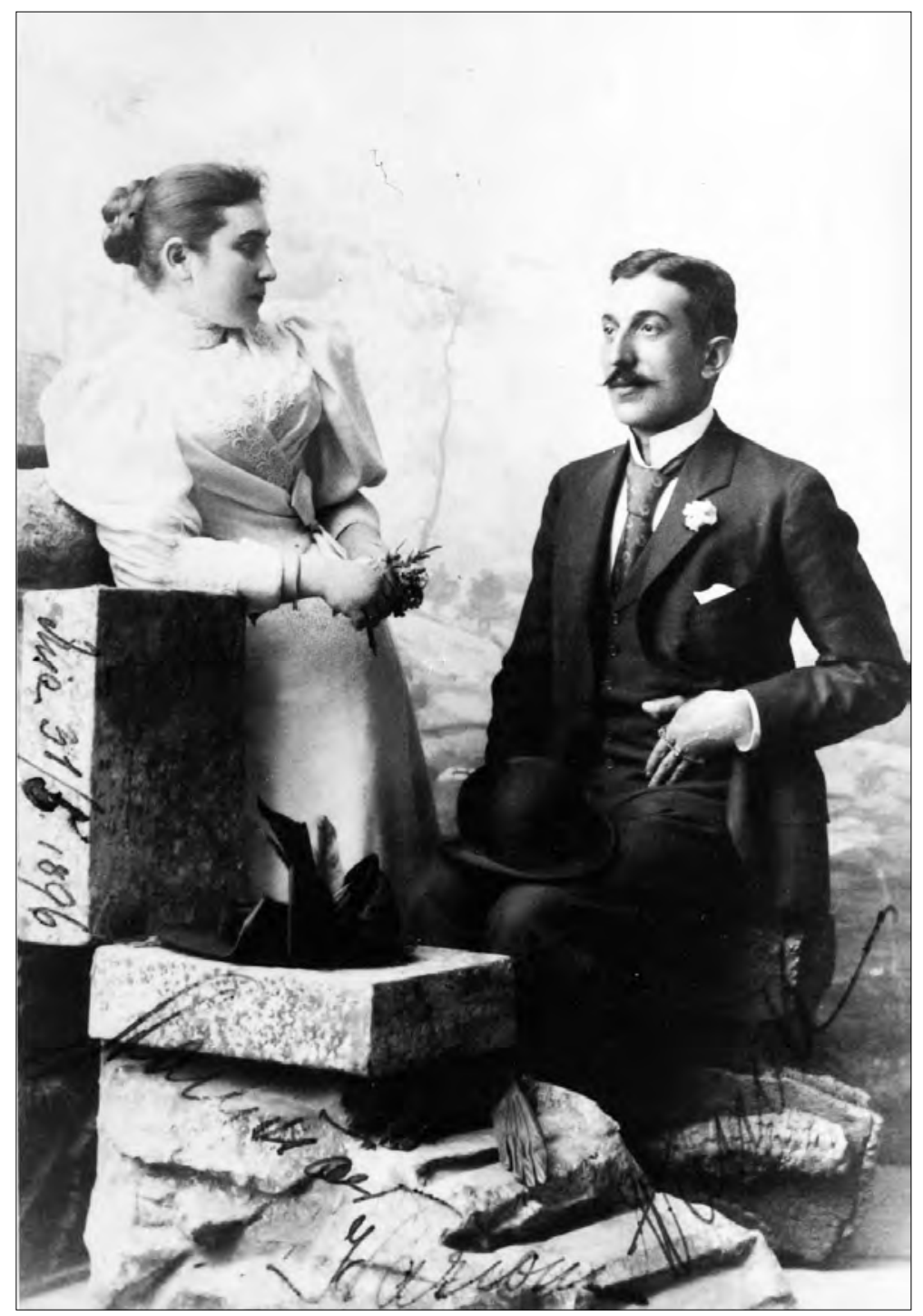

3. Stanisław i Wanda Bogdanowicz 
„Skoro tylko dowiedziałem się o Twej chorobie, zaraz odprawiłem Mszę św. na Twą intencję pragnąc odwdzięczyć Ci się za Twe modlitwy, o których nigdy nie wątpiłem, że mi towarzyszą, choć odpowiedzi na mój list nie otrzymałem.

Sprawa, która wówczas mnie absorbowała, zakończyła się pomyślnie nad wszelkie oczekiwanie, przynajmniej po ludzku sądząc, bo zawsze pewna reszta zjawisk życiowych tu na ziemi pozostaje dla nas znakiem zapytania. Ale modlitwy Twe są mi zawsze niezmiernie potrzebne, i nie tylko Twoje i nie tylko mnie, ale każdemu księdzu pracującemu na świecie... wśród świata... jest nas przerażająco mało w stosunku do ogromu pracy. Korespondowałbym z Tobą intensywniej, gdybyś miała czas na odpowiedzi: pisałbym $\mathrm{Ci}$ o moich pracach duszpasterskich i naukowych i o mych poglądach na kwestie mistyki i ascezy; pytałbym się o Twe zdanie w niejednej kwestii - i rad byłbym niezmiernie, bo mało, tak znikomo mało jest dusz, które się życiem wewnętrznym w jego głębi całej zajmują i interesują".

Jak z dalszych listów wynika, zaraz w początkach kapłaństwa stał się współtwórcą i zarazem pierwszym bibliotekarzem w powstałej wówczas w Warszawie, przy ul. Litewskiej 6 - Bibliotece Religijnej ${ }^{40}$ ufundowanej przez hr. Irenę Tyszkiewiczową ${ }^{41}$. Uchodząc z Ukrainy

\footnotetext{
40 Właściwie: Biblioteka Wiedzy Religijnej - została przez Irenę i Józefa Tyszkiewiczów w 1919 r. w Warszawie przy ul. Litewskiej 6. Głównym jej zadaniem było gromadzenie i bezpłatne udostępnianie literatury religijnej. Książnica funkcjonowała jako instytucja prywatna, choć formalnie została włączona do wspólnoty prowadzonej przez Różę Czacką w Laskach. Księgozbiór podzielono na kilkadziesiąt działów tematycznych: filozofia, różne gałęzie teologii w tym duchowość, biblistyka, mariologia, historia Kościoła, sztuka i archeologia chrześcijańska, pedagogiki itd. Z czasem zaczęto gromadzić także literaturę piękną, a w 1931 r. zorganizowano bibliotekę dla dzieci. Według spisu z 1939 r. księgozbiór składał się z 17000 tytułów literatury polskiej i obcojęzycznej oraz 100 tytułów czasopism. Biblioteka dla dzieci zawierała ok. 3000 tomów i 50 tytułów czasopism. Personel biblioteki składał się z kilku kobiet, które wraz z założycielką opiekowały się zbiorami i wypożyczały książki czytelnikom. Biblioteka istnieje do dnia dzisiejszego przy ul. Piwnej 9/11 i jest prowadzona przez siostry Franciszkanki Służebnice Krzyża. E. P r z y b y 1 - S a d o w s k a, Biblioteka Wiedzy Religijnej w Warszawie (1919-1939), „Z Badań nad Książką i Księgozbiorami Historycznymi”, 2016, t. 10, s. 211-227.

41 Irena Tyszkiewicz z d. Jezierska (1887-1964) - urodziła się w Garbowie na Lubelszczyźnie, ukończyła pensję sióstr Sacré Coeur w Pradze. W 1907 r. wyszła za mąż za Józefa Tyszkiewicza i zamieszkała w Spiczyńcach k. Berdyczowa. Podczas I wojny światowej Tyszkiewiczowie utracili swój majątek i wraz z synami Henrykiem
} 
na skutek rewolucji październikowej, uczyniła ona Bogu ślub, że o ile Bóg pozwoli jej wraz z rodziną ujść z życiem z tej pożogi, poświęci część uratowanych przez siebie kosztowności na ufundowanie Biblioteki Religijnej, przeznaczonej dla utwierdzenia w wierze i katolicyzmie dusz polskich ${ }^{42}$.

Bóg ją wysłuchał. Dotrzymała obietnicy - biblioteka powstała i przetrwała szczęśliwie przez 20 lat Polski międzywojennej, szerząc niepomiernie dużo dobra wśród dusz, spragnionych strawy duchowej. Najnowsze, najpoczytniejsze dzieła teologiczne, ascetyczne i religijne, jakie się tylko pojawiały na kontynencie europejskim w języku polskim, francuskim, niemieckim czy angielskim znalazły się na półkach biblioteki p[ani] Tyszkiewiczowej, z którą w utworzeniu tego wiekopomnego dzieła współpracował najściślej ks. Adam Bogdanowicz.

Ks. Arcybiskup Teodorowicz chciał go jednak mieć całkowicie dla pracy duszpasterskiej w [archi]diecezji ormiańskiej, dlatego też zmuszony był odwołać go od tej tak przez niego ukochanej i odpowiadającej jemu pracy. W jednym ze swoich uprzednio pisanych listów tak się wyraża ks. Adam o tej pracy: (list bez daty)

„O sobie co mam Ci donieść? Że mi dobrze, gdy mam dużo pracy, że lubię Warszawę, że przywiązałem się do niej, bo prąd umysłowego życia wartko tu płynie - żem się na uniwersytet zapisał (na filozofię)".

Odwołanie go z tej placówki warszawskiej, w której tkwił z całym zapałem swej młodocianej duszy, było niełatwym dla niego przeżyciem. Do tego doszła jeszcze druga sprawa: ks. Adam zapragnął, by mu Ks. Arcybiskup udzielił permanentnego pozwolenia na od-

\footnotetext{
i Krzysztofem przenieśli się do Warszawy. Tam związała się ze środowiskiem katolickiej inteligencji skupionej wokół ks. Władysława Korniłowicza. Od 1919 r. prowadziła w swoim domu przy ul. Litewskiej Bibliotekę Wiedzy Religijnej, zaangażowała się także w powstanie księgarni religijnej „Verbum” i czasopisma o tym samym tytule. Po śmierci męża, w 1943 r. wstąpiła do Zgromadzenia Sióstr Franciszkanek Służebnic Krzyża w Laskach i przyjęła imię Marii Franciszki. Była osobą niezwykle pracowitą i zaangażowaną w pomoc charytatywną m.in. w opiekę nad niewidomymi w Laskach. R. W o s i e k, Irena Tyszkiewiczowa - siostra Maria Franciszka (1887-1964), w: Ludzie Lasek, oprac. T. M a z o w i e c k i, Warszawa 1987, s. 250-265.

42 Opracowania poświęcone Bibliotece Wiedzy Religijnej jak również jej fundatorce podają, że pomysł zorganizowania biblioteki o profilu religijnym podsunął Tyszkiewiczowej ks. Władysław Korniłowicz. On też zakupił pierwsze 180 pozycji, które stanowiły zalążek biblioteki. Tamże, s. 255-256; E. P r z y b y ł - S a d o w s k a, Biblioteka Wiedzy Religijnej, s. 214.
} 
prawianie Mszy św. po łacinie (zamiast w obrządku ormiańskim). Ks. Arcybiskup przychylił się do tej jego prośby, jednakowoż udzielił mu tego pozwolenia nie na stałe tylko chwilowo W tej sprawie stanęła zdecydowanie po stronie Ks. Arcybiskupa Matka jego, o czym w liście z 30 X (chyba 1922 r.) ${ }^{43}$ tak pisze:

„Wczoraj jeden z przeciwników nieubłaganych moich pragnień liturgicznych (moja matka) nie była już tak agresywna jak dotąd, ale do ustąpienia jeszcze bardzo daleko, a wiesz jak Ks. Arc[ybiskup] jest wpływowy".

A pod datą 20 IX $1922^{44}$ [r.] tak się wyraża:

„Miałem list, w którym mówiono o «tolerowaniu» mej Mszy łacińskiej, a gdy odpisałem, że o tym nie może być mowy, gdyż otrzymałem wyraźne pozwolenie zanim jeszcze o papieskie się starałem ${ }^{45}$ i że mych starań nie zaniecham - otrzymałem zakaz odprawiania po łacinie, wobec czego odprawiam po ormiańsku i czekam co dalej z tego będzie".

Pod dniem 13 XI $1922^{46}$ [r.] tak pisze:

„Moja sprawa jest w fazie ostatecznej i poszła bardzo daleko... trzeba by cudu. Główną przeciwniczką mych pragnień jest matka, która używa całego swego wpływu przeciw mnie - nie mam do niej żalu (choć idzie tu o moje najżywotniejsze sprawy) wiem, że co czyni, czyni wedle swego sumienia - mam w Bogu nadzieję, że wszystko

${ }^{43}$ W rzeczywistości list pochodzi z 30 X $1923 \mathrm{r}$.

${ }^{44}$ W rzeczywistości list pochodzi z 20 IX $1923 \mathrm{r}$.

45 Nie uzyskawszy zgody od swojego ordynariusza abp. J. Teodorowicza na sprawowanie Mszy św. w rycie obrządku łacińskim ks. Bogdanowicz zwrócił się wiosną 1923 r. do Kongregacji Kościołów Wschodnich z prośbą o wydanie takiego indultu. W piśmie zaznaczył, że z modlitw mszalnych rozumie tylko pojedyncze słowa, a język ormiański jest dla niego obcy i niezrozumiały. Kongregacja zasugerowała ekskardynację ks. Bogdanowicza do diecezji obrządku łacińskiego. Sprawę komplikował fakt, że ks. Bogdanowicz wystosował pismo do Kongregacji bez wiedzy abp. Teodorowicza. Kolejnym powodem skłaniającym ks. Bogdanowicza do odejścia z archidiecezji lwowskiej obrządku ormiańskiego było odsunięcie go od pracy w Bibliotece Wiedzy Religijnej w Warszawie. Kard. Aleksander Kakowski metropolita warszawski wyraził zgodę na przyjęcie ks. Bogdanowicza do archidiecezji warszawskiej. Prośbę do Kongregacji Kościołów Wschodnich w tej sprawie wniósł zainteresowany w listopadzie 1923 r., ale na przeszkodzie realizacji tych planów stanął abp Teodorowicz, który z powodu niewielkiej liczby księży ormiańskich nie zgodził się na ekskardynację ks. Bogdanowicza. T. K r z y ż o w s k i, Archidiecezja lwowska obrządku ormiańskokatolickiego, s. 327-328.

${ }^{46}$ W rzeczywistości list pochodzi z 13 XI 1923 r. 
dobrze się skończy ku Jego chwale - ale modlitw trzeba coraz więcej, bo są to rzeczy po ludzku niemożliwe!".

Długo jeszcze ciągnęły się te jego zmagania z władzą kościelną o powrót do zajęć we właściwej diecezji swojego obrządku, o rezygnację z zajęć przy Bibliotece Religijnej, której organizacja wszystek czas jego pochłaniała ${ }^{47}$.

Wreszcie p[od] d[atą] 20 III 1923 r. $^{48}$ pisze co następuje:

„Jestem już w wirze zajęć innych niż w Warszawie: jestem wikarym katedralnym, przygotowuję prace doktorską (siedzę ciągle w bibliotece uniwersyteckiej), a poza tym niejedno duszpasterstwo się nawinie ${ }^{49}$. Możesz z tego wywnioskować, że moje starania nie odniosły skutku, a wszystkie obawy się spełniły, ale mniejsza o to, skorom zrobił wszystko, com mógł i do ostatka uczynił co uważałem za swój obowiązek reszta do Boga należy i Jemu też tę resztę zawierzam"50.

Nastąpiło kilka miesięcy intensywnych zajęć już we własnej diecezji, potem pewne zasłabnięcie fizyczne, leczenie się - potem wyjazd do Anglii, na zaproszenie Wizytek ${ }^{51}$ z Roselands (Walmer, Kent) ${ }^{52}$ miejscowości położonej nad morzem, oddalonej o 2 godz[iny] jazdy koleją od Londynu. W liście z 17 V 1924 r. zapowiadającym ten wyjazd tak się wyraża:

„Co do mojej sprawy to jestem tego zdania: gdy się swoje zrobiło resztę trzeba zawierzyć Bogu - również co do ustosunkowania się do ludzi, jestem zasadniczo Twego zdania: są to narzędzia i tyle, ale ostatecznie nie można w stosunkach z nimi nie brać w rachubę ich zacho-

47 Ks. Bogdanowicz zakończył pracę w Bibliotece Wiedzy Religijnej w listopadzie 1923 r. i wrócił do Lwowa, aby podjąć nowe zadania duszpasterskie.

${ }^{48} \mathrm{~W}$ rzeczywistości list pochodzi z 20 III $1924 \mathrm{r}$.

${ }^{49} \mathrm{Z}$ racji niewielu obowiązków duszpasterskich przy katedrze ormiańskiej ks. Bogdanowicz poświęcał czas na pracę naukową i rekolekcyjną.

${ }^{50}$ Aluzja do podjęcia pracy w archidiecezji ormiańskiej wbrew oczekiwaniom ks. Bogdanowicza oraz braku zgody na sprawowanie Mszy św. w obrządku łacińskim.

51 Zakon Nawiedzenia Najświętszej Maryi Panny nazywany popularnie wizytkami, założony w 1610 r. we Francji przez św. Joannę Franciszkę Fremyot de Chantal. W 1723 r. erygowano klasztor wizytek w Lublinie, jednak w wyniku prześladować i groźby kasaty wspólnoty przez władze carskie po powstaniu styczniowym grupa sióstr w 1866 r. przeniosła się do Himmelsthür w Królestwie Hanoweru. W 1875 r. wspólnota osiadła w Roselands Walmer w Anglii. Siostry prowadziły tam renomowaną szkołę dla dziewcząt. Rycerki Maryi. Z dziejów tułactwa sióstr wizytek lubelskich, Łuck 1936, s. 15-17.

${ }^{52}$ Roselands k. Walmer - miasto portowe w hrabstwie Kent w Anglii. 
wania się wobec nas - trudno zwracać się ze zwierzeniem tam gdzie się jest stale niezrozumianym, potępianym i w działaniu krępowanym - a stąd znów żale i pretensje, że się jest innym itd. - trudno, elementarna roztropność też jest cnotą".

W czasie swego blisko rocznego pobytu w Anglii ${ }^{53}$ dość często wysyłał listy, z których nietrudno było wyczuć jego postęp na drodze do doskonałości i stopniowe dojrzewanie w życiu duchownym. Oto wyjątek z listu pisanego p[od] d[atą] 1 VII 1924 r.:

„Jeśli opis doznanych przykrości ustnie może nie być skargą, gdyż mowa nadaje charakter treści - to o ile się o podobnych rzeczach pisze, wywołuje się nawet całkiem błędne wrażenie skargi; że zaś ostatni rok był dla mnie prawdziwie błogosławionym, bo więcej w nim miałem przykrości niźli w całym mym dotychczasowym życiu, a nawet więcej niźli niejeden ksiądz w całym swym życiu - wolałem milczeć, by uniknąć wrażenia że mi z tym źle! A zresztą nawet gdybym Ci opisał wszystko, czy nie uległabyś nazwiskom najużyteczniejszych ludzi w Kościele polskim? Nie oszczędzili mi żadnego zarzutu, żadnego co do rodzaju, bo co do stopnia to byli jeszcze łaskawi, dość powiedzieć, że w jednym liście jest aluzja do schizmy i herezji, a gdybym $\mathrm{Ci}$ powiedział od kogo, nie dałabyś wiary*. Jeszcze jeden rok podobny ostatniemu, a nie będę miał w ogóle co robić w kraju - jeśli Pan Jezus zechce mi dać powołanie do misji, to wstęp już zrobiony. Nie tylko zniweczono mi pracę i sparaliżowano program, ale serdecznie mi zbrzydzono środowisko, w którym podobne rzeczy są możliwe (gdybym Ci opowiedział szczegóły, to byś widziała że graniczą z fantazją!) Mam w tym wszystkim dużo pociechy: pierwsza, trochę złośliwa, w tym tkwi, że modlę się szczególnie za mych ,przyjaciół” i myślę sobie, że kiedyś będzie dziwnie zawdzięczać coś mnie, na którym suchej nitki nie zostawiali - druga to wielka wolność, którą daje taka sytuacja kompletnego odwiązania od pracy, od sławy, od planów na przyszłość - jednym słowem nihilizm kompletny w stosunku do stworzeń i sam na sam z Bogiem. Właściwie nic mnie w tej chwili ze światem nie łączy, chyba

\footnotetext{
* Chodziło tu o jednego z jego księży kolegów, który zazdroszcząc mu wyjątkowych zdolności i zapowiadającej się dla niego przyszłości w hierarchii kościelnej, nie ustawał w wysuwaniu przeciw niemu coraz to nowych, najniesłuszniejszych [sic!] zarzutów.

${ }^{53}$ Ks. Bogdanowicz przebywał w Anglii od maja 1924 r. do czerwca 1925 r.
} 
to jedno, że „nondum [usque ad sanguinem restitistis”(Hebr. 12,4)*, ale to dla mnie za wielkie chyba, że Jezus tak by dał. Ale są jeszcze inne role: jedni dają swą expansję, inni ją opłacają cierpieniem - cała rzecz w tym aby nie tylko tę rolę przyjąć, ale nie pragnąć nawet zmiany: o to też jedno Cię proszę, gdy się za mnie modlisz, byś prosiła abym Jezusowi zawsze zostawiał wybór mego krzyża i bym nigdy nie pragnął odmiany, bym sobie nigdy nie mówił: jaki mnie jutro czeka tryumf, skoro dziś tak drogo go opłacam, bym nawet nie pragnął usprawiedliwienia po śmierci, bym był gotów umrzeć nie tylko fizycznie, ale i moralnie dla całego świata! Więcej niczego nie chce pragnąć, ani o nic innego dla mnie nie proś gdy się cierpi to się tak traci poczucie wartości rzeczy ziemskich, że bez zasługi i wysiłku rezygnuje się z nich, po prostu wydają się śmieszne: jeden podmuch i cały dom z kart „croule” (zapada się) i czy warto choć kiwnąć palcem? by pod takim dachem zamieszkać?! A przy tym mam jeszcze tę wielką pociechę i szczególną łaskę, że nie doznaję żadnej pociechy: jest w tym zapewne miłość własna, ale nie chcę być zapłaconym za te przejścia, czuję się szczęśliwym na myśl, że mogę Bogu okazać że nie dla Jego darów kocham Go i służę $\mathrm{Mu}$ - o to też się pomódl, bym nigdy nie pragnął pociech, czynił to bez miłości własnej, a tylko z miłości Bożej. Jednym słowem jestem niewypowiedzialnie szczęśliwy - wprawdzie to nie ma sensu, ale tak jest - lękam się tylko, żeby w tym nie było wiele naturalnego zadowolenia, ale mam nadzieję że tak nie jest".

,[...] Co do Anglii, widzisz, to trudno mi wszystko w liście powiedzieć: oficjalnie jestem tu, by odbyć kurację morską - jestem kapelanem Wizytek w Walmer Kent nad samym morzem; po rannych obowiązkach, jestem wolny - o ile się dobrze czuję pracuję wciąż nad moją rozprawą doktorską „,De donis Spiritus S[ancti] Vitam Contemplativam Informantibus Secundum Doctrinam D[octoris] Thomae"54.

„[...] Pan Jezus blisko i „mój” (tak w myśli oznaczam te święte postacie, które sam konsekruję!), a zresztą nikt i nic. Zostaję tu do grudnia, o ile nie uda mi się zostać dłużej, a potem będzie co Pan Bóg da:

\footnotetext{
* „Jeszcze nie stawiałem oporu aż do przelewu krwi”. (Żyd. 12,4).

${ }^{54} \mathrm{~W}$ dokumentacji uniwersyteckiej związanej z przewodem doktorskim ks. Bogdanowicza temat rozprawy doktorskiej brzmi następująco: „De Donis Spiritus Sancti Vitam contemplativam informantibus Doctoris communis doctrina Pars I Generalis". Być może w trakcie pisania temat uległ modyfikacji. T. K r z y ż o w s k i, Archidiecezja lwowska obrządku ormiańskokatolickiego, s. 372.
} 
chcą ze mnie teraz zrobić asystenta uniwersytetu ${ }^{55}$ i forsować mnie na katedrę, że zaś prócz mego złego zdrowia nic nie stoi temu na przeszkodzie (chyba budżet państwa), a z czegoś żyć trzeba, wedle zasady: primum vivere, deinde philosophari ${ }^{56}$, a wreszcie można i przy tym trochę dobrego zrobić więc idę tą drogą, którą zresztą wolę od pracy społecznej, do której się nie czuję zdolny (a o duszpasterstwie w naszej diecezji wiesz co sądzić)",57.

O cierpieniu pisze w swym liście z Walmer Kent z dnia 1 IX 1924 [r.] co następuje:

„Gdy byłem na teologii zagadnienie osobistego szczęścia i cierpienia było dla mnie zagadnieniem teoretycznym, trudnym, skomplikowanym, najczęściej nierozwiązalnym w swych elementach. Przyszły przejścia rozmaite (najrealniejsza, zdaje mi się ofiara, to cierpliwe cierpienie) i z zagadnienia, z problemu dziś nic nie zostało prócz bezgranicznej ufności Sercu Jezusowemu: zdolność do cierpienia zamiera dopiero, gdy dusza odejdzie z tego padołu, ale lęk przed cierpieniem (u mnie) znikł i wraz z nim znikł cały problem. Dziś gdybym miał coś powiedzieć o cierpieniu, to jedno tylko potrafię powiedzieć, że jest ono tak samo proste jak proste jest całe życie z chwilą, gdy się je złożyło w ręce Jezusowe - jest tak proste, że więcej nic o nim nie da się powiedzieć: jest pewną fazą Woli Bożej, Woli miłościwej i miłosnej, czasem niezrozumiałej, ale skoro się żyje ufnością, jest to w gruncie rzeczy całkiem obojętne czy się rozumie czy nie - i problemu niema. Muszę dodać, że ten ostatni wyraz mego zapatrywania jest już owocem ostatnich mych przejść, bo praca, którą mi odjęto była ostatnią i jedyną rzeczą, do której byłem przywiązany (zdaje się że w najsłuszniejszym i najnaturalniejszym znaczeniu tego słowa) - a skoro to odpadło, znikła wszelka trwoga, bo już nic więcej nie mam do stracenia, - a z trwogą i wszelka komplikacja”.

I dalej w tymże liście:

„[...] by doróść do cierpienia, trzeba cierpieć z miłością i miłować w cierpieniu, wtedy zdobywa się klucz do sztuki cierpienia.

\footnotetext{
55 Uniwersytetu Jana Kazimierza we Lwowie.

${ }^{56}$ Łac.: najpierw żyć, potem filozofować.

57 Nawiązanie do niewielkiej i rozproszonej liczby wiernych archidiecezji ormiańskiej, co nie wymagało od kapłanów takiego zaangażowania w pracę duszpasterską jak miało to miejsce w innych diecezjach na obszarze Małopolski Wschodniej.
} 
[...] Przepraszam Cię, że Cię ukarałem tak długim listem za Twą poczciwość, ale powiada jakieś dowcipne przysłowie: „Toute bonne action est toujours punie en ce monde" (Każdy dobry uczynek bywa ukarany na tym świecie) - nie jest to takie głupie mimo paradoksu!

O sobie mogę Ci tyle powiedzieć: siedzę tu 3 miesiące i jeszcze nie mówię po angielsku, a nawet bez słownika nie mogę się obejść w czytaniu potocznej literatury. Moim osobistym celem tu jadąc było nauczyć się języka, bo to dla moich celów konieczne (czeka mnie jeszcze włoski, a może i hiszpański - potem będzie dosyć, chyba że zamiast tego potrzebniejszym okazałby się rosyjski). Kiedy i dokąd stąd ruszę nie wiem, bo wszystko ode mnie nie zależy, a osobistych planów dziś właściwie nie mam - jedna możliwość to pozostanie tu jeszcze blisko rok, inna [to] powrót w grudniu, połączona z objęciem asystentury przy uniwersytecie lwowskim, tamta z możliwością udania się do Rzymu by pracować w Międzynarodowej Centrali Stowarzyszeń Katolickich ${ }^{58}$, gdzie Polska dotąd nie ma swego agenta. Pomódl się by mi angielszczyzna prędzej i lepiej szła do głowy: bez angielskiego nie można być znawcą „literatury teologicznej”, co jest moim fachem, choć moje zajęcie może być całkiem inne".

P[od] d[atą] 3 XII 1924 [r.] pisze co następuje:

„Mam teraz sezonowy bilet i dojeżdżam koleją (2 godziny) do British Museum $^{59}$, gdzie byłem przyjęty przez dyrektorów niesłychanie uprzejmie i dopuszczony do badania ich wewnętrznych urządzeń, ale w teologii katolickiej mają luki „skandaliczne”, całą moc książek naukowych pierwszorzędnego znaczenia posiada Biblioteka Wiedzy Religijnej (w Warszawie), których „British Museum” nie ma!

„W dniu 8 XII [1924 r.] mszę odprawię na Twą intencję życząc Ci na Imieniny, by Ci Pan Jezus dał ten ogień miłości, co ziemię w czyściec przemienia swym palącym żarem, ale za to prosto do nieba wiedzie!!!"

Na samo Boże Narodzenie wybrał się do Lisieux ${ }^{60}$ skąd wysłał mi kartkę ze zdjęciem białego płaszcza, welonu i wieńca róż, które święta ${ }^{61}$

\footnotetext{
${ }^{58}$ Organizacja niezidentyfikowana.

59 British Museum - jedno z największych muzeów na świece założone w 1753 r. w Londynie.

${ }^{60}$ Lisieux - miejscowość we Francji w Normandii, miejsce życia i kultu św. Teresy od Dzieciątka Jezus.

${ }^{61}$ Chodzi o św. Teresę od Dzieciątka Jezus.
} 
miała na głowie w dniu swej profesji. Nawiązując do tego pisze $\mathrm{p}$ [od] d[atą] 4 VI 1925 [r.] jeszcze z Anglii (5 VI 1925 [r.]):

„W Lisieux nie starałem się nawet widzieć którąkolwiek ze Sióstr Świętej; kilka z nich, zdaje się, żyje jeszcze. Święta leży w bocznej kaplicy na prawo od wejścia za kratami, przez które bez przerwy publiczność rzuca kwiaty wokół sarkofagu".

Ostatni swój list z Anglii p[od] d[atą] 16 VI (1925 [r.]) pisał po angielsku chcąc mnie przekonać o tym, jaki uczynił postęp w tym języku, a na przyszłość zapewnić sobie możliwość korespondowania w tymże języku dla zapobieżenia ew. utracie tego, co pod tym względem nabył. Oto jeden z charakterystycznych urywków tegoż listu:

„Thanks for the newspaper cuttings though of course for me they are not much agreable: they show once more how thoroughly I was standered, since the name of mine, who have made and organized and done everything for the library ${ }^{62}$, is not even mentioned and all the people who have standered me are anjoying their full esteem - of course it is usual way in this world and I do not mind it: I am only ashamed for the people concerned and to belong to the some profession to whick they belong and where such things are possible.

You can't imagine what a pain it is for an apostolic vocation to be practically condemned to inactivity - my prayers are very simply now: God, let me work for you and the souls or else let me die - What's the use of a priest whom God doesn't allow to become a religious if he may be hampered doing any pastoral work too? Of course I don't need to tell you that with the grace of God I am ready to andure it as long as He pleases, but after accepting His holy will we can still pray according to our desires (Our Lord has prayed thus too in the Garden Gethsemany). Now then I am answerning Your letter: I think sanctity is very well compatible with a certain narrow - mindedness: the reason is very simple - sanctity - though it is essentially love of God and charity (of the next) - has still some particular feature in every single saint now in this respect he must be perfect (f[or] i[nstance] St. Francis of Assisi $^{63}$ and poverty) but in other respects he can be well imperfect

\footnotetext{
${ }^{62}$ Chodzi o Bibliotekę Wiedzy Religijnej w Warszawie.

${ }^{63}$ Franciszek z Asyżu (1181-1226) - urodzony we włoskiej rodzinie kupieckiej jako Giovanni Bernardone, w młodości zajmował się handlem i rzemiosłem rycerskim. W 1205 r. przeżył głębokie nawrócenie, obrał drogę pokuty i poświęcił się wędrownemu kaznodziejstwu. W 1209 r. uzyskał dla siebie i swoich uczniów od papieża
} 
(f[or] i[nstance] St. Francis of Assisi and theological studies) which he nearly disapprouved!!!

Don't think I am unselfish in saying the Masses: if one suffers hopelessly oneself, one has only one consolation: to lessen sufferings of other sufferers.

It's my last letter written from England: I am leaving on Friday, stoping at Louvain ${ }^{64}$, Berlin, Cracov and arriving at Lwów the $30^{\text {th }}$ of this month".

Tłumaczenie powyższego listu:

„Dziękuję Ci za przysłane mi wycinki gazet, choć dla mnie osobiście, nie są one zbyt przyjemne, świadczą bowiem o tym jak starannie mnie wykluczono, nawet nie wspomniano mojego imienia, choć ja przecież zorganizowałem i wszystko uczyniłem dla tej Biblioteki - ci zaś którzy mnie $\mathrm{z}$ niej wykluczyli w całej pełni, zażywają dobrej sławy oczywiście taki jest zwykły bieg spraw na tym świecie i ja właściwie nie przywiązuję wagi do tego. Wstydzę się tylko za odnośne osoby i wstydzę się też, że należę do tej samej branży co i oni, do branży, w której takie rzeczy mogą się zdarzyć.

Nie możesz sobie wyobrazić, jakim to cierpieniem dla duszy apostolskiej, kiedy zostanie skazaną praktycznie na bezczynność - moje modlitwy bardzo są proste teraz: Boże, pozwól mi pracować dla Ciebie i dla dusz, albo spraw, abym umarł. - Jakiś pożytek może być z kapłana, któremu Bóg nie pozwoli wstąpić do zakonu, a który wciąż napotyka na przeszkody w duszpasterskiej pracy. Oczywiście nie potrzebuję Cię zapewniać, że z łaską Bożą gotów jestem znieść ten stan rzeczy tak długo jak się Bogu spodoba - ale przy zupełnym poddaniu się Woli Bożej, zawsze wolno nam modlić się o spełnienie naszych pragnień. (Zbawca nasz też modlił się w ten sposób w Ogrojcu).

A teraz odpowiem Ci na Twój list: Myślę, że Świętość może iść w parze z pewną ciasnotą umysłu: przyczyna jest bardzo prosta. Świętość, chociaż o niej stanowi w gruncie rzeczy Miłość Boga i miłość

Innocentego III ustne zatwierdzenie ustaw przyszłego zakonu franciszkanów (ostateczna wersja reguły powstała w 1223 r.) oraz przyjął święcenia diakonatu. W 1212 r. po przyjęciu do wspólnoty Klary z Asyżu powstała żeńska gałąź zakonu. W 1219 r. udał się z pielgrzymką do Ziemi Świętej. W 1224 r. na Górze Alwerni otrzymał stygmaty. Pochowany w Asyżu, kanonizowany w 1228 r. A. Ż y n e 1, Franciszek z Asyżu, [w:] EK, t. 5, red. P. H e m p e r e k, Lublin 1989, kol. 426-427.

${ }^{64}$ Louvain - miasto w Belgii, siedziba m.in. znanego uniwersytetu katolickiego. 
(bliźniego), to ona jednak przyjmuje w każdym ze świętych jakieś specjalne rysy: więc pod w/w względami musi dany święty wykazać się doskonałością (np. św. Franciszek pod wzg[lędem] ubóstwa) ale pod innymi względami może mieć pewne niedoskonałości (np. św. Franciszek z Asyżu i studia teologiczne) których on w ogóle nie uznawał!!!

Nie myśl tylko, że ja taki jestem bezinteresowny w ofiarowaniu Mszy św. kiedy człowiek tak cierpi bez widoków na jakąś ulgę, wtedy znajduje ulgę jedyną w możliwości ulżenia cierpienia innych ludzi cierpiących.

To jest ostatni mój list pisany z Anglii: wyjeżdżam w piątek i po zatrzymaniu się nieco w Leodium ${ }^{65}$, Berlinie i Krakowie przybędę do Lwowa w dniu 30 bm.”.

Po powrocie do kraju i przekonaniu się, że osiągnięcia jakie zamierzył zdobyć swoją pracą doktorską, stały się nieaktualne - tak pisze o swoich planach na najbliższą przyszłość: (Lwów, 17 VII [19]25)

„Moja praca, zrobiona pod naciskiem okoliczności (materialnych) wraz z ich zmianą zniesienie przez rząd wszystkich asystentur przy uniwersytetach $^{66}$ stałą się nieaktualna i leży w jakiejś szufladzie".

A p [od] d[atą] 4 IX 1925:

„Organizuję wydawnictwo przekładów teologicznych ${ }^{67}$, które ma rocznie produkować co najmniej 4 tomy z różnych dziedzin teologii, a więc ascetyczno-mistycznej, dogmatycznej i moralnej, historycznej

\footnotetext{
${ }^{65}$ Błąd autorki, chodzi o miasto Louvain (łac. Lovanium), a nie miasto Liège (łac. Leodium).

66 Informacja błędna; w okresie dwudziestolecia międzywojennego na uczelniach państwowych w Polsce funkcjonowało stanowisko asystenta starszego, młodszego oraz zastępcy asystenta, które zaliczano do pomocniczych sił naukowych. $\mathrm{Na}$ Wydziale Teologicznym Uniwersytetu Jana Kazimierza we Lwowie istniały dwie kategorie asystentur: przy wybranych katedrach oraz przy Bibliotece Zakładów Teologicznych. Asystenci pracowali czasowo przy następujących katedrach: sztuki kościelnej, teologii fundamentalnej, homiletyki, katechetyki i pedagogiki. Starszymi asystentami mogły zostać osoby legitymujące się dyplomem uczelni wyższej, natomiast stanowisko asystentów młodszych i zastępców asystentów obejmowali studenci wyższych lat studiów. J. W ołc z án s ki, Wydział Teologiczny Uniwersytetu Jana Kazimierza we Lwowie 1918-1939, Kraków 2002, s. 80-81, 99, 110-111.

67 Właściwie: Biblioteka Przekładów „Veritas” - jeden z działów Towarzystwa Biblioteka Religijna we Lwowie, działający w latach 1925-1939 pod kierownictwem ks. Adama Bogdanowicza i ks. Karola Csesznaka. Celem wydawnictwa było tłumaczenie na język polski i drukowanie wartościowych publikacji z różnych gałęzi teologii. T. K r z y ż o w s k i, Archidiecezja lwowska obrzqdku ormiańskokatolickiego, s. 463.
} 
i biblijnej - wreszcie obok tego chciałbym stworzyć bibliotekę przekładów beletrystycznych ${ }^{68}$ i wydawałbym najlepsze katolickie powieści i nowele zagraniczne".

A p[od] d[atą] 19 II 1926 r.

„Oddałem moją pracę doktorską (nie mając najmniej nadziei, by czas mi pozwolił przełożyć ją na język polski) ${ }^{69}$ taką jaką ją w Anglii napisałem był - mam nadzieję wziąć po Wielkanocy dłuższy urlop i jeszcze przed wakacjami mieć pół doktoratu za sobą - druga połowa zostanie na r[ok] 1926/7 a potem planuję 2 wyjazd na studia do Niemiec - o ile plany się nie zmienią, będę się teraz specjalizować w N[owym] Zakonie, który zawsze był mi najdroższą dziedziną teologii, ale skrupuły, że filologiem nie byłem i nie jestem ${ }^{70}$ powstrzymywały mnie zawsze i kierowały ku dogmatyce, obecnie jednak widzę, że dogmatyka nigdy mi nie wystarczy, bo za wiele w niej spekulacji a za mało samego Jezusa, a filologami też nie są wszyscy egzegeci: bądź co bądź nie musi się być koniecznie lingwistą, by być historykiem a wiadomości językowe można czerpać z drugiej ręki, tak jak to czyni ogół historyków innych epok".

W marcu tegoż r[oku] 1926 wypadł mu wyjazd do Abbazii ${ }^{71}$ z Ks. Arcyb[iskupem] Teodorowiczem, który po odbytej ciężkiej chorobie był bardzo osłabiony i potrzebował opieki oraz pomocy ks. Bogdanowicza. Przebywali obydwaj w Ice ${ }^{72}$ (Privincia Fiume) ${ }^{73}$ Italia - Sanatorio Sacerdote ${ }^{74}$. Ks. Bogdanowicz korzystając z okazji zwiedził w drodze Wenecję i Padwę. Choć Ks. Arcyb[iskup] był gotów go zatrzymać i w perspektywie nawet mu stawiał i w końcu zapropono-

${ }^{68}$ Biblioteka Przekładów Beletrystycznych - planowana seria wydawnicza z zakresu literatury religijnej, miała być prowadzona równolegle z Biblioteką Przekładów „Veritas” jednak wskutek problemów organizacyjnych nie doczekała się realizacji. Tamże.

${ }^{69}$ Praca doktorska ks. Bogdanowicza napisana była w języku łacińskim.

${ }^{70}$ Aluzja do braku biegłości w starożytnych językach biblijnych niezbędnej do pracy naukowej w tym zakresie.

71 Abbazia - znana miejscowość uzdrowiskowa na półwyspie Istria nad Adriatykiem, obecnie Opatija w Chorwacji.

${ }^{72} \mathrm{Ika}$ - miejscowość wypoczynkowa na półwyspie Istria nad Adriatykiem, obecnie na terenie Chorwacji.

73 Prowincja Fiume - włoska prowincja istniejąca w latach 1924-1947 ze stolicą w mieście Fiume (Rijeka), obecnie w granicach Chorwacji.

74 Wł.: Sanatorium dla kapłanów. 
wał podróż do Rzymu, on jednak jak sam pisze „uciekł z Włoch” (w połowie IV [19]26).

W połowie maja znalazł się we Lwowie, gdzie go czekały gorączkowe zajęcia. Dobijał bowiem doktoratu, a przy tym miał tam więcej duszpasterstwa inteligentnego ${ }^{75}$, o którym tak się wyraża (list z $17 \mathrm{~V}$ ):

„bez niego nie potrafiłbym się uczyć... to trudno: jestem księdzem od włosów do paznokci i bez duszpasterstwa jestem nieszczęśliwy, chory, do niczego - jest to zapewne b[ardzo] niedoskonałe, bo kontemplacja powinna wystarczyć, ale mam na swoją obronę

a) że w zakonach kontemplacyjnych prócz kontemplacji jest jeszcze wewnętrzne życie klasztorne, które może absorbować ekspansję

b) nawet u eremitów warunki życia nie kontrastują ich kontemplacji z „Heilbedürfnis”,76 ich otoczenia, które w świecie zbyt się narzuca, by można w nim żyć, a nie pragnąć go zbawiać.

Jestem dziś stanowczo nudny, ale to na skutek ostatnich wypadków w kraju* które mnie utwierdziły w przekonaniu, że (dla księdza) nie warto się niczym innym zajmować jak teologią (Bogiem) i duszami.

Moje plany na przyszłość są takie: po wakacjach I. rygorozum (z wszystkich dogmatycznych nauk), przed Bożym Narodz[eniem] II. rygorozum (z Pisma św.), przed Wielkanocą (1927) III. rygorozum (z prawa i historii) tak, że w maju (1927) spodziewam się być doktorem. Oczywiście nie przywiązałbym do tego najmniejszej wagi, gdyby nie to, że muszę przez to przejść chcąc iść naprzód „karierą” naukową - potem przygotuję pracę habilitacyjną na styczeń $1928 \mathrm{r}$. i w tym roku zostanę docentem: otrzymanie katedry zależy już potem tylko od opróżnienia się jednej z nich na którymś z uniwersytetów ${ }^{77}$.

\footnotetext{
* Chodzi tu zapewne o wypadki majowe 1926 r.

$75 \mathrm{Tj}$. duszpasterstwa dla inteligencji.

${ }^{76}$ Niem.: potrzeba uzdrowienia, zbawienia.

77 W okresie międzywojennym w Polsce Wydziały Teologiczne funkcjonowały na następujących uczelniach: Uniwersytecie Jagiellońskim (Kraków), Katolickim Uniwersytecie Lubelskim (Lublin), Uniwersytecie Jana Kazimierza (Lwów), Uniwersytecie Warszawskim (Warszawa), Uniwersytecie Stefana Batorego (Wilno). Szkoły Wyższe Rzeczypospolitej Polskiej, Warszawa 1930, passim. Nie wiadomo czy ks. Bogdanowicz podejmował starania o angaż na którejś z wymienionych wyżej uczelni poza macierzystą.
} 


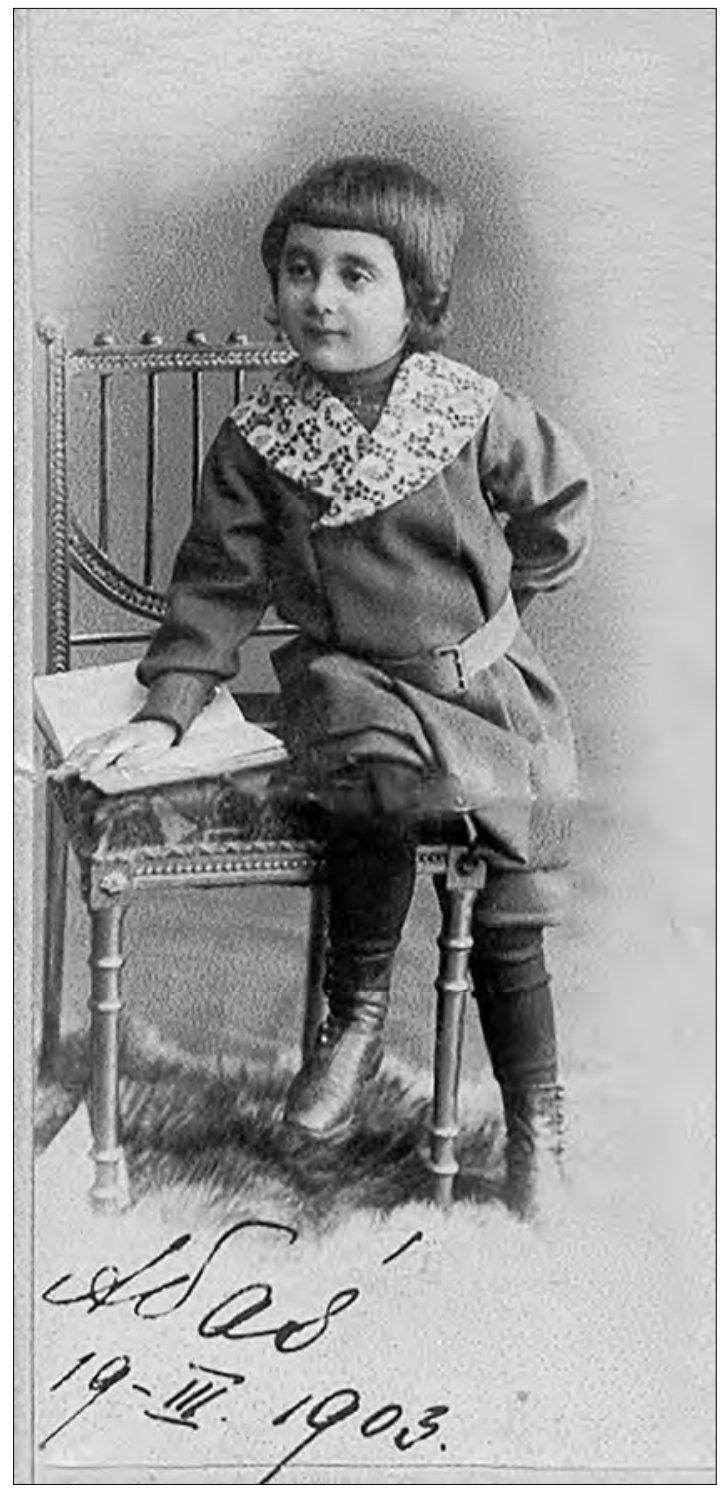

4. Adam Roszko-Bogdanowicz, Lwów 1903 r. 
Pomyśl sobie że A[rcybiskup]* zaproponował mi bym wniósł prośbę o brewiarz ł[aciński], który On poprze - zdaje się, że to było wyrazem podzięki za moje usługi w podróży na południe ${ }^{78}$, ale dotąd nie dałem żadnej odpowiedzi i nie wiem co robić - przyjąć to znaczyłoby tym samem zobowiązać się do wdzięczności czyli albo zapomnieć o moralnym policzku - nie mówiąc ,przebaczyć” bo to jest obowiązkiem, ale ,zapomnieć” może być czasem une lacheté ${ }^{79}$, uwłaczającą godności własnej - albo być fałszywym: pamiętać a mimo to stawiać się w stosunku wdzięczności, gdyby wpierw choć jednym słowem zanulowano krzywdę moralną, wówczas byłoby coś innego - (a i wtedy nie wiem czybym przyjął). Co o tym sądzisz? Napisz mi koniecznie! Mam też trudne warunki finansowe, ale to ostatecznie najmniejsze, chodzi tu głównie o matkę, nie o mnie samego".

List bez daty ${ }^{80}$ :

„Jestem chwilowo wszystkim: kanclerzem Kurii, administratorem katedry, sekretarzem arcybiskupa ${ }^{81}$ etc. etc., tak że nie mam sekundy czasu. Często za mało na wysłanie (zaklejenie i ofrankowanie ${ }^{82}$ ) już napisanego listu - nie dziw się więc, że nie odpisuję: donieś kiedy przyjeżdżasz i kiedy będzie można z Tobą swobodnie porozmawiać jestem wolny około 8. wieczorem, rzadko wcześniej, rano prawie nigdy, a jeżeli to od jakiej 10 dopiero począwszy".

\section{List z 9 X 1926 r.:}

„Verba docent, exempla trahunt" ${ }^{\prime 83} \mathrm{w}$ tym razie za Twoim niezbyt budującym przykładem rozchorowałem się i leżę w łóżku: (nic mi nie jest, tylko przeziębienie). Wedle Twego życzenia będę pisał o sobie: otóż mam całkiem dosyć zawiadywania kasami, urzędowania jako sekretarz - przemyśliwania nad tym, jakby się znów wyrwać i wyje-

\footnotetext{
${ }^{*}$ Chodzi tu zapewne o J[ego] E[ekscelencję] Ks. Arcyb[iskupa] Teodorowicza.

${ }^{78}$ Aluzja do pobytu z abp. Teodorowiczem w Abbazii od marca do kwietnia $1926 \mathrm{r}$.

${ }^{79}$ Fr.: nikczemnością.

${ }^{80}$ Prawdopodobnie rok 1926.

${ }^{81}$ Ks. Bogdanowicz był w tym czasie wikariuszem katedry ormiańskiej we Lwowie, dyrektorem zakrystii oraz katechetą w szkole żeńskiej, funkcję kanclerza Kurii Arcybiskupiej pełnił ks. Dionizy Kajetanowicz, natomiast sekretarza abp. Teodorowicza ks. Leon Isakowicz. Przypuszczalnie ks. Bogdanowicz zastępował wyżej wymienionych kapłanów stąd natłok pełnionych obowiązków. Schematismus archidioecesis leopoliensis ritus armeno-catholici pro Anno Domini 1926, Leopolis 1926, s. 14-15, 19.

${ }^{82}$ Automatyczne nadrukowywanie na kopercie opłaty pocztowej.

${ }^{83}$ Łac.: Słowa uczą, ale pociąga przykład.
} 
chać, ale wiem, że to nie będzie łatwa sprawa, bo ksiądz Arcybiskup uważa mnie za „potrzebnego" tu cała moja praca umysłowa od czasu powrotu do Lwowa zupełnie się urwała, bez nadziei, by tu się coś zmieniło na lepsze: była chwila, gdy zdawało się, że będę mógł dostać asystenturę uniwersytecką, ale i ta nadzieja spełzła na niczym!

Możesz sobie wyobrazić, czym dla mnie, zamiłowanego teologa, jest: zajmowanie się czekami, kwitami, piecami, kominami, wodociągami etc. aż do zmęczenia, które nie pozwala mi już czytać nic poważnego - a tymczasem teologia patrzy na mnie żałośnie z półek i z wyrzutem się odzywa głosem nadchodzących czasopism, na które nie mam czasu! Ale jestem dobrej myśli: dotąd chciałem studiów - w tym roku (od lipca) zrezygnowałem! Może właśnie, dlatego Pan Bóg teraz tak rzeczy obróci, że będę mógł nareszcie i raz na zawsze oddać się teologii - nie będzie to rzeczą łatwą, ale w tym jedna racja więcej, by się tego od Boga spodziewać. Gdybym się wyrzekł duszpasterstwa (spowiadam 5 dni w tygodniu po 2,3 czasem do 6 i 7 godzin po p[ołudniu] i 5 razy odprawiam benedykcję ${ }^{84}$, nie licząc kazań), to może bym zyskał czas na studia, ale:

1) gdy nie mam duszpasterstwa, tak mi ono brakuje, że nie potrafię się skupić w pracy czysto intelektualnej;

2) uważam, że bądź co bądź ksiądz jest w pierwszym rzędzie na to, by duszom służył, a nie by pisał naukowe rozprawy dla specjalistów. Tylko gdybym mógł obok duszpasterstwa pracować umysłowo, mógłbym się na to zgodzić, ale na to trzeba bym albo dostał ową asystenturę, albo bym skądinąd umiał wydobyć te dochody, które są niezbędne, by mi dać więcej czasu dla mnie samego. - Zresztą mimo wszystko ukradkiem jadąc tramwajem, albo wyczekując gdzieś w banku czytam ile mogę i w żadnym razie nie uważam się za "nieszczęśliwego" przeciwnie! Byle mieć czas na modlitwę, reszta mniejsza!

No, wypisałem się o sobie aż za dużo: teraz wyglądam Twego przyjazdu, byle tylko nie nastąpił zanim wydobrzeję i zacznę wychodzić!" Stan ks. Bogdanowicza mimo tak optymistycznych prognoz, jakie samemu sobie postawił, nie poprawił się; zapadał coraz bardziej w ten stan ostatecznego wyczerpania nerwowego. Doprowadzały go do tego zajęcia nieodpowiednie dla niego, do których usiłował się nakłonić. Ponieważ lekki stan podgorączkowy wciąż trwał, więc go lekarze

${ }^{84}$ Dawne: błogosławieństwo. 
wysłali pod Zakopane do Rokicin Małopolskich ${ }^{85}$ (powiat Chabówka). Tam w Sanatorium dla kapłanów ${ }^{86}$ spędził blisko 4 miesiące: grudzień 1926, styczeń, luty i marzec 1927 r. Oto urywek jednego z jego listów z 30 I 1927 r.:

„Nie mam płuc wcale zajętych, jest to dobrze, ale mam głowę tak zmęczoną, że dotąd jeszcze (po dwóch miesiącach pobytu tu, nie licząc zawieszenia pracy we Lwowie przez ostatni miesiąc tam spędzony) nie tylko nie mogę, ale nawet nie mam najmniejszej chęci coś poważnego czytać - jest mi tu idealnie, ale ostatecznie takie ciągłe wyjazdy i kuracje to są paliatywy: na to bym był stale zdrów, trzeba bym przestał być i sekretarzem i wikariuszem katedralnym i miał czas na studia - te praktyczne zajęcia nerwowo mnie zabijają. Dlatego obecnie marzę tylko o wyjeździe do Rzymu na dwa lata i może coś się da zrobić. Pomódl się za mnie o możliwe warunki pracy umysłowej i duszpasterskiej, bo obecne są niemożliwe i muszą doprowadzić do choroby".

Po opuszczeniu sanatorium powrócił na cały kwiecień do Lwowa a potem znów wpadł w niebywały ruch. Oto co na ten temat pisze w liście z 8 VI 1927 r. z Krakowa:

„Byłem w ciągłym ruchu i jestem. Od lutego do teraz 6 razy w Krakowie, raz w Zakopanem, raz w Poznaniu i Gostyniu ${ }^{87}$, raz w Tarnowie i Okocimiu ${ }^{88}$, po raz drugi w Zbylitowskiej Górze ${ }^{89}$ (powiat Tarnów) dokąd teraz stąd podążam, w przededniu wyjazdu do Lublina. Widzisz, że w takim ruchu trudno o spokój - pewno mnie spytasz co mną tak gna? Sprawy archidiecezji i Arcybiskup, z przygodną przerwą drogi dla własnego programu. Czuję się dobrze odkąd słońce świeci, gdy mogę się wygrzewać na upale, ku zgrozie widzów, przepowiadających na próżno udar słońca - czuję się dobrze, bo nie widzę Lwowa ze wszystkim co doń należy. Ostatnio po powrocie z Rokicin (po 4 miesiącach)

\footnotetext{
85 Właściwie: Rokiciny Podhalańskie - miejscowość wypoczynkowa kilka kilometrów na południowy zachód do Rabki Zdroju.

86 Podczas pobytu w Rokicinach Podhalańskich ks. Bogdanowicz mieszkał u sióstr urszulanek.

${ }^{87}$ Gostyń - miasto w Wielkopolsce na południe od Poznania.

${ }^{88}$ Okocim - wieś w Małopolsce, gmina Brzesko.

${ }^{89}$ Zbylitowska Góra - wieś w Małopolsce k. Tarnowa; znajduje się tam klasztor i szkoła sióstr Sacrè Coeur.
} 
Gluziński ${ }^{90}$ orzekł, że mam zatrucie systemu nerwowego toksyną z gruczołów płucnych, co tylko słońce może z organizmu dobyć, a że słońca przez zimę nie było, więc i te 4 miesiące „kuracji” ponoć mi nie pomogły - że zaś w Polsce ,il y a dix mois d'hiver et deux mois de mouveis temps"* jak $\mathrm{Ci}$ wiadomo, więc należałoby jechać do Afryki. Na razie brak mi do szczęścia mej biblioteki (duszpasterstwa miałem dość, choć nigdy za dużo - od Zbylitowskiej Góry aż do Poznania i od Zakopanego do Częstochowy - wszędzie je uprawiałem) - z dwojga wolę duszpasterstwo od studium, wolałbym jednak studium od interesów, może i to z czasem się odmieni.

Ks. Arcyb[iskup] w Marienbadzie - matka moja z Babcią w Dżurowie $^{91}$ - przez lipiec będę pewno siedział we Lwowie, a co z sierpniem będzie tego nie wiem: może Kuty ${ }^{92}$, gdzie proboszcz ${ }^{93}$ nie odprawia Mszy już od miesięcy, ani żadnych innych funkcji nie sprawuje (chory) - może Hallerowo ${ }^{94}$, dokąd mnie generał Haller ${ }^{95}$ zaprasza $^{2}$

${ }^{90}$ Lesław Gluziński (1858-1932) - lekarz, absolwent Uniwersytetu Jagiellońskiego (1883), ceniony specjalista z zakresu chorób układu oddechowego i gruźlicy. Autor publikacji naukowych. Praktykował w uzdrowiskach w Szczawnicy, a następnie we Lwowie. Brat profesora medycyny Antoniego Władysława Gluzińskiego. wW. Szumowski, Gluziński Lesław, [w:] PSB, t. 8, red. K. Le p s z y, Wrocław-Kraków-Warszawa 1959-1960, s. 87-88.

*[Fr.] ,Jest 10 miesięcy zimy, a dwa miesiące niepogody”.

91 Dżurów - miejscowość w dawnym powiecie Śniatyn, w województwie stanisławowskim, obecnie na Ukrainie W Dżurowie miał swoje dobra i dwór Kazimierz Bohdanowicz, brat Wandy Bogdanowiczowej, matki ks. Adama.

92 Kuty - miasteczko w dawnym województwie stanisławowskim, obecnie na Ukrainie. Znajdowała się tam m.in. siedziba ormiańskokatolickiej parafii pw. Niepokalanego Poczęcia NMP.

93 Od 1910 r. proboszczem parafii ormiańskokatolickiej w Kutach był ks. Samuel Manugiewicz.

${ }^{94}$ Hallerowo - osada na terenie Wielkiej Wsi w powiecie Puck nad Bałtykiem, obecnie dzielnica Władysławowa. Nazwa pochodzi od nazwiska gen. Józefa Hallera, który w 1920 r. nabył tam kilkuhektarową parcelę i wybudował dom.

95 Józef Haller (1873-1960) - kształcił się w Hranicach i Wiedniu, w 1895 r. został podporucznikiem artylerii polowej w Armii Austro-Węgier, następnie zaangażował się w działalność społeczną, m.in. w Towarzystwie Gimnastycznym „Sokół” i harcerstwie. W czasie I wojny światowej dowódca polskich formacji wojskowych: 3 Pułku i II Brygady Legionów Polskich oraz 5 dywizji Strzelców Polskich. Awansowany do stopnia generała brygady (7 IV 1918) i generała broni (21 IV 1920). Od 4 X 1918 r. dowódca Armii Polskiej we Francji (tzw. Błękitnej Armii), uczestnik wojny ukraińsko-polskiej (1919) i wojny polsko-bolszewickiej (1920). W 1. 1920-1926 pełnił 
na swą kolonię letnią „błękitnych drużyn”96 - może coś innego jeszcze, a może jeszcze Lwów: ignoro et ignorabo ${ }^{97}$ bo do ostatniej chwili, jak zwykle u nas. W najbliższym czasie drugi tomik naszego wydawnictwa pójdzie do druku: Madeleine Semer, convertie et mystique ${ }^{98}$ powoli to idzie: nie mam czasu, by się temu całkowicie oddać!!!99 Petitot $^{100}$ jest istotnie najlepszą książką o św. Teresce ${ }^{101}$, tłumaczą karmelitanki z Przemyśla ${ }^{102}$ a podjął się przejrzenia ks. Żychliński ${ }^{103}$

funkcje administracyjne w wojsku, m.in. Generalnego Inspektora Artylerii, a także przewodniczącego Związku Harcerstwa Polskiego (1920-1923), prezes Polskiego Czerwonego Krzyża (1920-1926), poseł na sejm z listy Chrześcijańskiego Związku Jedności Narodowej (1922-1923). Przeciwnik przewrotu majowego w 1926 r., za co przeniesiono został w stan spoczynku. W czasie II wojny światowej członek Rządu Polskiego na Uchodźstwie, w 1939 r. został ministrem bez teki, a następnie ministrem Oświaty (1940-1943). Po wojnie pozostał na emigracji w Wielkiej Brytanii; zmarł w Londynie. W 1993 r. jego prochy sprowadzono do Polski i umieszczono w krypcie kościoła garnizonowego św. Agnieszki w Krakowie. Odznaczony Srebrnym Krzyżem Orderu Virtuti Militari (1920), Orderem Orła Białego (1921), Krzyżem Komandorskim Orderu Odrodzenia Polski (1922) i in. M. Orło w s k i, Generał Józef Haller 1873-1960, Kraków 2007, passim.

96 Błękitne Drużyny - organizacja młodzieżowa przy Związku Hallerczyków działająca w Polsce w okresie międzywojennym.

97 Łac.: Nie wiem i nie będę wiedział.

98 Właściwie: F. Kle i n, Une expérience religieuse: Madeleine Sémer, convertie et mystique (1874-1921), Paris 1923.

${ }^{99}$ Przekład powyższej książki na język polski nie ukazał się drukiem.

${ }^{100}$ Petitot Henri (1880-1934) - ur. we Francji, w 1899 r. wstąpił do zakonu dominikanów, w 1904 r. przyjął święcenia kapłańskie, w latach 1906-1914 był wykładowcą filozofii i teologii, a latach 1925-1927 przeorem klasztoru w Amiens. Autor publikacji z filozofii i duchowości, m.in. o Teresie z Lisieux i objawieniach w Lourdes. S. B r z o z e c k i, Petitot Henri, [w:] EK, t. 15, red. E. G i g i l e w i c z, Lublin 2011, kol. 390. 101 Chodzi o książkę: L. H. Pe ti t ot, Sainte Thérèse de Lisieux: une renaissance spirituelle, Paris 1925.

102 Książka ukazała się nakładem ss. karmelitanek bosych: Święta Teresa z Lisieux: odrodzenie duchowe, Przemyśl 1927.

103 Aleksander Żychliński (1889-1945) - święcenia kapłańskie przyjął w 1913 r. w Poznaniu, studiował teologię na Uniwersytecie Gregoriańskim w Rzymie, a następnie na Uniwersytecie Wrocławskim, gdzie w 1917 r. uzyskał doktorat z teologii. W 1. 1917-1918 był wikariuszem w Gostyniu, od 1918 r. wykładowca teologii dogmatycznej w Seminarium Duchownym w Poznaniu, w latach 1927-1929 rektor Seminarium Duchownego w Gnieźnie, w czasie II wojny światowej wykładowca teologii w Seminarium Duchownym w Kielcach. Był cenionym spowiednikiem i kierownikiem duchowym, znawcą dzieł mistyków chrześcijańskich, autorem książek z teologii, duszpasterzem młodzieży akademickiej Juventus Christiana. Zmarł w Gnieźnie 
z Poznania - oby dobrze przejrzał tzn. radykalnie, bo styl karmelitanek jest tak pobożny, że trzeba wielkiej pobożności, aby go przełknąć. Recenzja ${ }^{104}$ Louismet'a $^{105}$ pióra O. Rostworowskiego ${ }^{106}$ ubawiła mnie serdecznie: widać że nie zna literatury, ale nie kryje się z tym. Byłem umyślnie u niego i przyznał się że nie zna ani GarrigouLagrange'a $^{107}$ ani Gardeil'a ${ }^{108}$, ani Menendez-Reigad'y ${ }^{109}$, więc po cóż

w opinii świętości, w 1967 r. rozpoczął się jego proces beatyfikacyjny. M. K o n i e c z n y, Żychliński Aleksander, [w:] EK, t. 20, red. E. Gi gi l e w i c z, Lublin 2014, kol. 1623-1624.

104 J. R o s t w o r o w s k i, rec.: S. Louismet, Życie mistyczne, przełożyła W. Grafczyńska, Lwów „Biblioteka Religijna” 1927, str. 220, „Przegląd Powszechny”, 1927, t. 173, s. 248-249.

105 Louismet Irenée Savinien (1858-1926) - francuski benedyktyn, teolog i mistyk, w 1882 r. przyjął święcenia kapłańskie, wyjechał na misje i pracował duszpastersko wśród Indian w USA. W 1902 r. wrócił do Francji i został przeorem klasztoru w Buckfast oraz rekolekcjonistą. Jest autorem szeregu prac z zakresu życia duchowego i mistyki, które przetłumaczono na wiele języków. E. Zi e m a n n, Louismet Irenée Savinien, [w:] EK, t. 10, red. E. Z i e m a n n, Lublin 2004, kol. 1409.

106 Rostworowski Jan (1876-1963) - jezuita, studiował filozofię w Nowym Sączu i teologię w Krakowie, w 1903 r. przyjął święcenia kapłańskie, w zakonie pełnił szereg funkcji: był wykładowcą teologii dogmatycznej w Krakowie (1904-1906, 1907-1912), rektorem Zakładu Naukowo-Wychowawczego w Chyrowie (1913-1915), superiorem w Krakowie (1918-1919), prof. teologii w Starej Wsi (1919-1920), dyrektorem Wydawnictwa Księży Jezuitów (1926-1936), superiorem Domu Pisarzy w Warszawie (od 1939), superiorem w Poznaniu (1945-1949), redaktorem i współpracownikiem czasopism religijnych: „Sodalis Marianus”, „Przegląd Powszechny”, „Wiara i Życie”, „Posłaniec Serca Jezusowego”, „Moderator”. Autor publikacji religijnych, rekolekcjonista. Rostworowski Jan, [w:] Encyklopedia wiedzy o Jezuitach na ziemiach Polski i Litwy 1564-1995, oprac. L. G r z e b i e ń, Kraków 1996, s. 578.

107 Garrigou-Lagrange Réginald (1877-1964) - dominikanin, święcenia kapłańskie przyjął w 1902 r., studiował filozofię i teologię we Flavigny-sur-Ozerain i w Paryżu, w latach 1909-1960 prof. teologii w rzymskim Angelicum, był również konsulatorem Kongregacji Świętego Oficjum i Kongregacji ds. Zakonów. Jeden z czołowych neotomistów XX w., krytyk modernizmu, występował przeciwko zwolennikom tzw. nowej teologii, autor cenionych publikacji z teologii dogmatycznej, życia duchowego oraz komentarzy do Summy Teologicznej św. Tomasza z Akwinu. K. K l a u z a, GarrigouLagrange Réginald, [w:] EK, t. 5, red. P. H e m p e r e k, Lublin 1989, kol. 873-874.

${ }^{108}$ Gardeil Ambroise (1859-1931) - francuski dominikanin, teolog i filozof, w 1893 r. został rektorem studiów zakonnych prowincji paryskiej, w 1. 1904-1911 wykładał w kolegium dominikańskim w Saulchoir (Belgia), współzałożyciel czasopisma „Revue thomiste", autor publikacji z zakresu epistemologii, apologetyki, teologii i mistyki. K. M a r c i n i a k, Gardeil Ambroise, [w:] EK, t. 5, red. P. H e m p e r e k, Lublin 1989, kol. 864-865. 
tak bezwzględnie występuje? Zrobił nam jednak reklamę i zaraz 500 egz[emplarzy] na skutek jego recenzji sprzedaliśmy. (Ks. Błotnicki ${ }^{110}$ odpowiedział dobrze, ale podejrzewam nie przeczytawszy książki, tylko pierwsze i ostatnie strony - lepiej to niż nic) ${ }^{111}$.

Rok 1927 był ważną datą w życiu ks. Bogdanowicza, bo w drugiej jego połowie otrzymał nominację na proboszcza Horodenki ${ }^{112}$, z tym że dwa pierwsze tygodnie w miesiącu miał tam spędzać na drugie zaś dwa miał powracać do Lwowa, by tam nadal prowadzić wyznaczone sobie zajęcia ${ }^{113}$.

109 Menéndez-Reigada Albino González (1881-1958) - hiszpański dominikanin, święcenia kapłańskie przyjął w 1905 r., obronił doktoraty z teologii i prawa cywilnego na uniwersytetach w Salamance i Madrycie. Studia kontynuował w Berlinie, Rzymie i Fryburgu Szwajcarskim. Po powrocie do Hiszpanii w 1912 r. został prof. filozofii, etyki i prawa na Katolickiej Akademii Uniwersyteckiej, redaktorem czasopisma „Ciencia Tomista” i kaznodzieją króla Alfonsa XIII Burbona. Autor szeregu prac z teologii, rekolekcjonista i społecznik. W 1. 1925-1946 biskup ordynariusz Teneryfy, w 1. 1946-1958 biskup ordynariusz Kordoby. https://cordobapedia.wikanda.es/wiki/ Obispo_Fray_Albino [dostęp: 6.07.2020].

110 Franciszek Błotnicki (1890-1952) - katolicki duchowny, publicysta i działacz społeczny. Święcenia kapłańskie przyjął w 1914 r. we Lwowie, pracował w redakcji czasopism: „Głos Narodu”, „Gazeta Kościelna”, „Gwiazda Polski” i in., działał w Związku Dziennikarzy Polskich i Komitecie Teatralnym na Śląsku, w czasie II wojny światowej zaangażował się w tajne nauczanie i zorganizował gimnazjum. Jest autorem licznych artykułów prasowych i broszur z tematyki religijnej oraz utworów poetyckich. S. P a w li n a, Błotnicki Franciszek, [w:] EK, t. 2, red. F. Gry g le w i c z, Lublin 1976, kol. 686-687.

${ }^{111}$ F. B [ 1 o t n i c k i], rec.: Savinian Louismet, Życie mistyczne, Lwów 1927. Nakładem i drukiem Tow[arzystwa] „Biblioteka Religijna”, str. 212, „Gazeta Kościelna”, 1927, nr 7, s. 82.

112 W Horodence na Pokuciu funkcjonowała parafia ormiańskokatolicka pw. Niepokalanego Poczęcia NMP. W latach 1927-1935 ks. Bogdanowicz był jej administratorem, a nie proboszczem.

113 Takie rozwiązanie było spowodowane zapewne brakami kadrowymi w szeregach duchowieństwa archidiecezji ormiańskiej. Było jednak uciążliwe zarówno dla ks. Bogdanowicza jak i dla parafian, którzy z posługi duszpasterskiej i sakramentalnej mogli korzystać tylko w wyznaczone okresy czasu. Ks. Bogdanowicz nominację na administratora w Horodence uważał za zesłanie na prowincję, o czym świadczy relacja Heleny Mycielskiej: „Dowiedziałam się wtedy od ks. Adama, że jest on systematycznie tępiony zarówno przez duchowieństwo jak i przez świeckich. Z uśmiechem mówił o banicji na wiejskie probostwo ormiańskie w Horodence, gdzie go zesłano, żeby nie mącił wody. Powód? Głównie ten, że rzekomo nieroztropnie, na siłę wprowadza do polskiego katolicyzmu zalecenia encykliki Piusa X Sacra Tridentina odnośnie częstej, a nawet codziennej Komunii św. Polscy duchowni uważają mianowicie (lata między- 
Oto urywek z jego listu pisanego z Horodenki p[od] d[atą] 12 XI 1927 r.:

„Wczoraj przyjechałem do Horodenki - w tym miesiącu tylko na 8 dni, bo już w niedzielę 20/XI po sumie jadę do Lwowa, a stamtąd do Poznania na Zjazd Lig Katolickich ${ }^{114}$ z całej Polski"115.

Praca duszpasterska jednak mimo wszystko jest i pozostaje na zawsze głównym postulatem jego dążeń. Pisze w odniesieniu do tego p[od] d[atą] 13 II 1928 r.:

„Dzięki Ci za Twój trud i za Twoje dobre słowa: nie są one daremne - nie uwierzysz jak mi czasem potrzeba usłyszeć zachętę, tak krytycznie mimo nich zapatruję się na moje próby pracy - nie ma obawy abym jakikolwiek rezultat sobie miał przypisać - mój udział jest czysto negatywny: wszystkie braki tej pracy są moje - Bóg się wprawdzie w Swym miłosierdziu mną posługuje dla Swych celów, ale mego jest w tym tyle, że Mu przeszkadzam: na szczęście nie jest w mej mocy dzieło Boże całkiem udaremnić!"

I dalej p[od] d[atą] $6 \mathrm{~V} 1928 \mathrm{r}$ :

„Zdaje mi się, że Tobie w ostatnim liście dziękowałem za modlitwy, dzięki którym moje duszpasterstwo wielkopostne nie było bezowocne z całą pewnością rezultaty osiągnięte są raczej Waszą niż moją zasługą, a jeśli jest w tym i mojej, to nie dlatego że mówię, tylko dlatego że mnie to tyle kosztuje: odpowiedzialność za każdą naukę i kazanie mnie przygniatała choć konfesjonał ani trochę mi nie ciąży".

A oto jedna ze światłych rad, jakich mi udzielał w swoich listach:

wojenne!), że nasze społeczeństwo nie jest przygotowane do takiego zwyczaju, który łatwo mógłby się przerodzić w lekceważenie Najświętszego Sakramentu”. Archiwum Fundacji Kultury i Dziedzictwa Ormian Polskich w Warszawie (dalej: AFKiDOP)b.sygn., H. M y c i e 1 s k a, Wspomnienie o ks. Adamie Bogdanowiczu, Kraków 1983, mps, s. 1.

114 Liga Katolicka - stowarzyszenie erygowane w 1919 r. podczas konferencji episkopatu w Gnieźnie i Częstochowie. Liga była organizacją apolityczną, jej celem było pogłębienie prawd wiary i formowanie katolików świeckich, przeciwstawianie się propagandzie antykatolickiej oraz obrona interesów Kościoła. W tym celu organizowano zjazdy, prelekcje, akcje dobroczynne, popierano wydawnictwa katolickie. Działalność Ligi stanowiła podstawę organizacyjną i ideową późniejszej Akcji Katolickiej i do 1934 r. została włączona w jej struktury. M. Le s z c z y ń s k i, Liga Katolicka, [w:] EK, t. 10, red. E. Z i e m a n n, Lublin 2004, kol. 1035-1037.

115 W 1933 r. ks. Bogdanowicz został delegatem Akcji Katolickiej z archidiecezji ormiańskiej. 


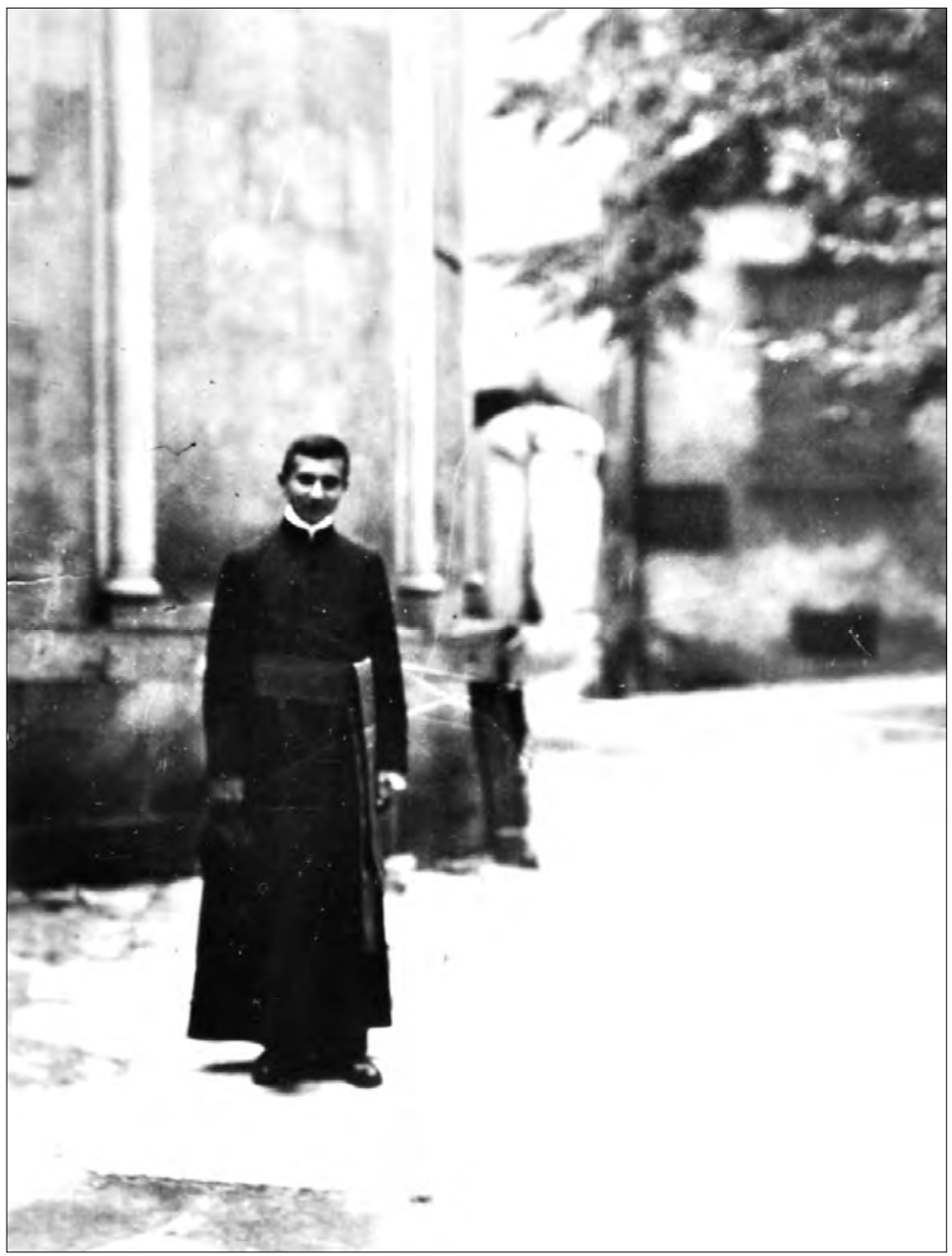

5. Alumn Adam Roszko-Bogdanowicz na tle katedry ormiańskiej we Lwowie 
„Roztropność ma kierować nie tylko cnotami głównymi, ale i wyrazem cnót Boskich, ich zewnętrzną ekspresją a więc niegodnemu wiary nie należy wierzyć, bo tak nakazuje roztropność, a miłość będzie i w tym zachowana, gdy się ten sceptycyzm będzie stosować nie bezwzględnie, ale tylko w rzeczach doniosłych lub przy zupełnej pewności o kłamstwie".

A pod dniem $9 \mathrm{~V}$ 1928:

„Nie mogę powiedzieć bym brał wszystko tak bardzo nad przyrodzenie i tak bardzo poważnie: ,pour moi un crasse est tout d'abord une crasse",* - a dopiero potem szukam w tym moralnego sensu „une tuile est une tuile"* - a dopiero potem myślę z tego zrobić cnotę - ale też właśnie dlatego nie biorę rzeczy tak bardzo poważnie: nie wszystko co się dzieje jest Wolą Bożą, niejedno jest tylko dopustem i choć w tym charakterze służy chwale Bożej i duszom, nie wymaga apologii ani historiozofii specjalnej - il faut sovoir voir le côté humoristique des choses*: życie ma często więcej pomysłów humorystycznych od komediopisarzy".

„Ks. Arcybiskup jest w Rzymie ${ }^{116}$. Obecnie ważą się losy: moje osobiste i projektowanego organu* już stąd napisałem list do Rzymu, gdzie prosiłem albo o carte blanche ${ }^{117} \mathrm{~W}$ pracy redaktorskiej albo o pozostanie w Horodence, kto wie czy się na tym nie skończy, choć wolałbym pierwsze.

Dn[ia] 28 V 1928:

„Rozumiem Cię doskonale, ale mam wrażenie, że jesteś może odrobinkę za pesymistyczna, gdy się uciekasz do słów wytykających winę moralną - często to nie brud, ani bagienko tylko po prostu „,cielęctwo" - poczciwe, dobroduszne ograniczenie, któremu się zdaje, że ratuje Kościół i w tym przekonaniu potrafi nawet udrapować się

* [Fr.] Dla mnie świństwo jest najpierw świństwem.

* [Fr.] Dachówka jest dachówką.

* [Fr.] Trzeba umieć dojrzeć stronę humorystyczną w każdej rzeczy.

* Chodziło o czasopismo „Gregoriana”, organ archidiecezji lwowskiej ob.[rządku] orm[iańskiego] Tak zwanego dla św. Grzegorza Oświeciciela, Patrona Kośc[ioła] orm[iańskiego], którego redaktorem miał zostać ks. Bogdanowicz.

116 Od maja do lipca 1928 r. w Rzymie miały miejsce obrady Konferencji Episkopatu Kościoła ormiańskokatolickiego, w której uczestniczył także abp Teodorowicz.

${ }^{117}$ Fr.: wolną rękę. 
w „męczeństwo" spełnionego obowiązku, gdy bliźniemu nogę podstawia - (a propos znasz to przysłowie: na to człowiek ma dwie nogi, by na jednej stał, a drugą bliźniemu podstawiał?!).

W drugiej połowie tegoż r. 1928 zwierzył mi się ks. Adam z rzeczy, która mnie niemało zaskoczyła. Matka jego (58 lat mająca) zapragnęła wstąpić do klasztoru. W liście z 3 IX 1928 r. pisze mi tak:

„Mamusia mi pisała, że Ci się zwierzyła ze swoim pragnieniem wstąpienia do klasztoru, więc do Ciebie się z tym zwracam, lecz bez wiedzy Mamusi, tylko od siebie. Zbadaj teren i napisz jak sprawy stoją - najważniejsza rzecz to pytanie, czy w ogóle zamiary Matki mają przed sobą widoki urzeczywistnienia? Chciałbym byś mi to szczerze napisała, aby Mamusi oszczędzić niepotrzebnych i przykrych iluzji - o mojej Matce mogę powiedzieć zupełnie bezstronnie, że jest osobą nieprzeciętnej cnoty, którą nie wahałbym się nazwać heroiczną (podobnie określa ją Ks. Arcybiskup, który jest kierownikiem [duchowym] Matki) o gorącym duchu apostolskim, o czym świadczy jej praca społeczna (przewodnicząca organizacji narodowej $\mathrm{V}$. okręgu we Lwowie $^{118}$ - prezydentka Kongregacji Kochawińskiej ${ }^{119}$ - inicjatorka i organizatorka wypożyczania dobrych książek subiektom i pannom sklepowym po sklepach $^{120}$ ) wszystko to w duchu prawdziwego

\footnotetext{
118 Właściwie: Narodowa Organizacja Kobiet - organizacja społeczno-polityczna związana ideowo z Narodową Demokracją, istniała w 1. 1919-1939. Do jej zasadniczych celów należało uświadomienie polityczne kobiet oraz zaktywizowanie ich na gruncie życia społeczno-politycznego. Członkinie stowarzyszenia deklarowały przywiązanie do Kościoła katolickiego i promowały chrześcijańskie wartości. Nacisk kładziono na formację członkiń organizując wykłady i kursy. Cele organizacji realizowano poprzez działalność społeczno-kulturalną, oświatową i charytatywną. J. M y s i a k o w s k a - M u s z y ń s k a, „W imię Boga i Ojczyzny”. Działalność społecznopolityczna Narodowej Organizacji Kobiet 1919-1939 - wybrane zagadnienia, „Dzieje Najnowsze", 47(2015), nr 3, s. 33-36, 40-41.

119 Kongregacja pw. Matki Boskiej Kochawińskiej - organizacja społeczno-religijna zrzeszająca kobiety ze sfery ziemiańskiej i inteligenckiej, erygowana w 1902 r. w Kochawinie z inicjatywy abp. Józefa Teodorowicza i ks. Jana Trzopińskiego; działała na terenie Kresów południowo-wschodnich Rzeczpospolitej do II wojny światowej. Kongregacja podzielona była na kilka sekcji, m.in. religijną, oświatową, opieki nad młodzieżą, biblioteczną. Działalność skupiała się wokół pracy oświatowo-wychowawczej dzieci i młodzieży, organizacji kursów i kolonii, pomocy charytatywnej, prowadzeniu biura pośrednictwa pracy, prenumeraty katolickich czasopism. Ponadto dbano o formację religijną członkiń poprzez spotkania formacyjne, rekolekcje i nabożeństwa. T. K r z y ż o w s k i, Archidiecezja lwowska obrzadku ormiańskokatolickiego, s. 577-583.
} 
apostolstwa - przy tym wszystkim przed Bogiem raczej nieśmiała (a więc raczej zbyt pokorna - przesadnie) - tak, że o ile znam się na tym, nie przedstawiałaby trudności, jako materiał zakonny, ale ma 58 lat i ani grosza i ani jednego dyplomu - ma dobry albo bardzo dobry styl polski i zna francuski na tyle, że mogłaby tłumaczyć no i wie tyle, a może i daleko więcej od niejednej pani ze wsi o ogrodzie, gospodarstwie itd. Ogród doliniański (nasz dawny majątek Doliniany) był podobno wzorowo utrzymany, ale żadnego fachowego wykształcenia oczywiście Mamusia nie ma. Nadawałaby się do literackiej pracy, ale jest tak nieśmiała w tym, że wszystko idzie do pieca, jeśli się nie przeszkodzi. Matka ma temperament sangwiniczny, ale przy tym wyrobioną, silną wolę i stanowczą być potrafi dla siebie i, jeśli trzeba, dla drugich - należy do typu osób, które nie potrafią posłużyć się żadnym kompromisem, całkowitych bez względu na skutki.

O sobie nic nie mam do doniesienia: wracam około 20 IX do Horodenki. Dotąd nic nie ma postanowionego, ani z Hor[odenką] (z którą mnie nic nie łączy prócz finansów) ani z „Paxem"121 (jeszcze nie istniejącym, z którym znów wszystko mnie łączy, ale też, niestety, prócz finansów!). To co piszesz o ufności jest całkiem słuszne: Ufność jest lewą stroną miłości - bez niej nie byłoby miłości - jest ona jej koniecznym warunkiem, a więc w pewnym sensie jej nierozłączną, drugą stroną - bo tylko od miłości Boga ku nam zapala się nasza miłość od nas ku Niemu, a tę miłość Bożą dla nas przyjmujemy tylko przez ufność, więc tak, że dając Bogu dużo ufności dajemy $\mathrm{Mu}$, en fin de compte* - wiele miłości, bo przez Twą ufność Jego miłość znajduje dostęp do Twej duszy i w niej rozjarza miłość ku Niemu".

List z 1 X 1928:

„Jeżeli w moim liście robiłem różnicę między konferencjami a duszpasterstwem to dlatego, że nieraz już słyszałem o sobie jako o „mówcy”, gdy tymczasem ja się wcale za takiego nie mam - mam pewną łatwość mówienia, ale mówię abstrakcyjnie, oderwanie, teoretycznie, niepopularnie i prawdopodobnie nudno, więc też znając te wady, a nie mając czasu ani sposobu nad tym specjalnie pracować, mówić nie

\footnotetext{
${ }^{*}$ [Fr.] W ostatecznym rozrachunku.

120 Była to jedna z gałęzi działalności Kongregacji Ziemianek pw. Matki Boskiej Kochawińskiej.

121 Organizacja niezidentyfikowana.
} 
lubię ${ }^{122}$. Nigdy nie odmawiam, gdy jestem proszony, bo uważam to w takim razie za swój obowiązek. Czasami może i sam się ofiaruję lub zdecyduję mówić, gdy mi się zdaje, że mimo wszystko to się może na coś przydać - ale zawsze to czynię w poczuciu, że to robię marnie".

List z dnia 4 X 1928:

„Te sądy ludzkie zmieniają się jak pogoda. Teraz spotkała mnie b[ardzo] pochlebna propozycja: (Kanonia Kapitulna), której nie mam zamiaru przyjąć ${ }^{123}$. Nie widzę racji byś pierwsza miała szukać i zbliżać się do osób, które by mogły z każdego słowa Twego wyciągnąć jakieś wnioski. Sama roztropność każe nie iść w sidła, ale oczywiście, gdy się zbliżają, nie dać im poznać, co myślisz, czujesz czy wiesz, o ile to tylko ukryć potrafisz.

Mamusi X. Arcybiskup nie puszcza do zakonu, bo uważa, że nie ma powołania, co bardzo możliwe, że jest prawdą".

List z października 1928 (bez daty):

„Kłamstwo i obłuda nie są zjawiskiem pierwotnym tylko pochodnym, tj. że nie występują same dla siebie, tylko jako środek na usługach innej namiętności (miłości własnej, nienawiści, chciwości etc.)”.

23 XI 1928 r.:

„Polityka jest sztuką, a sztuka nie jest złem - tylko, sama w sobie, rzeczą obojętną - a dobrem lub złem (staje się) zależnie od użytku. Istnieje dobra polityka, o której u św. Tomasza ${ }^{124}$ coś by się znalazło -

\footnotetext{
122 Ta wypowiedź ks. Bogdanowicza mocno kontrastuje z opinią, że był dobrym mówcą, o czym świadczą wspomnienia osób, które go znały, m.in. Jadwigi Knaus, Krystyny Góreckiej, Heleny Mycielskiej, Anny Sidorowicz. AFKiDOP, b.sygn., Wspomnienia o ks. Adamie Roszko Bogdanowiczu, passim.

123 Kanonikiem gremialnym Kapituły Katedralnej obrządku ormiańskokatolickiego ks. Bogdanowicz został w $1933 \mathrm{r}$.

124 Tomasz z Akwinu (1225-1274) - ur. w Roccasecca k. Neapolu we włoskiej rodzinie hrabiów Akwinu, pobierał nauki w opactwie na Monte Cassino oraz studiował nauki wyzwolone w Neapolu, gdzie wstąpił do zakonu dominikanów. Od 1245 r. odbywał nowicjat w Paryżu, od 1248 formację i studia kontynuował w Kolonii, w 1250 r. przyjął święcenia kapłańskie. W 1256 r. uzyskał stopień magistra teologii w Paryżu i prowadził wykłady z Pisma św. W 1259 r. wrócił do Italii, gdzie przebywał w klasztorach w Neapolu, Orvieto, Rzymie, Viterbo poświęcając się pracy pisarskiej, wykładom z teologii oraz kaznodziejstwu. W 1269 r. objął katedrę teologii w Paryżu. Zmarł w drodze na Sobór w Lyonie, jego relikwie spoczywają w Tuluzie. W 1323 r. kanonizowany, w 1567 ogłoszony Doktorem Kościoła. Jest autorem fundamentalnych prac z teologii i filozofii, m.in. dzieła Summa Theologie. S. B r z o z e c ki, Tomasz z Akwinu, [w:] EK, t. 19, red. E. G i g i l e w i c z, Lublin 2013, kol. 848-849.
} 
jest to sztuka wymagana u przełożonych - przede wszystkim względem podwładnych, ale i w ramach administracji w ogóle nie jest mi zbyt trudno podejrzewać Cię o pewne niedocenianie tej zalety „wyjścia” z ludźmi - mam wrażenie, że w imię prostoty i szczerości odrzucasz jako dyplomację samą roztropność, chciałem tylko skorzystać z okazji, by Cię przestrzec przed możliwością skrajności i to wszystko. Ileż razy robimy głupstwo, a Bóg jego ślady zaciera, bo Opatrzność Jego tak chce - kiedy indziej drobiazg z naszej strony wywołuje lawinę - dlaczego? Znów, bo On tak chce - posługuje się nieraz drobiazgiem, by wywołać cały proces naszej ewolucji, której przejścia nasze i przeżycia są tylko warunkami zewnętrznymi”.

15 I 1929 r.:

„U Ciebie obawiałbym się nie tyle połowiczności ile raczej skrajności: co innego nie poczuwać się i nie przyznawać do czynionych zarzutów, a co innego brać je sobie do serca nie tyle dlatego, że (człowieka) dotykają, ale nawet jako objaw pewnego powiedzmy - ujemnego stanu umysłów - chociażby tak istotnie było czego nigdy pewni być nie możemy, bo ludzie z racji swego ograniczenia raczej nam dokuczają, z nieświadomości (through sheer stupidity) ${ }^{*}$ a nie ze złości, to trzeba $\mathrm{Ci}$ - na ile tylko potrafisz - abstrahować z tego i tak żyć jakby takiego ujemnego nastawienia duchownego wokoło Ciebie nie było - to znaczy byś $\mathrm{w}$ swoim postępowaniu praktycznym nie miała się z tym liczyć: tego domaga się roztropność, masz też wewnętrznie - o ile potrafisz - „chasset toute préocupation de cet ètat de choses de ton espirit"* tak jak twoje przeciwniczki błądzą tym, co naśladowanie nazywa zajmowanie się z zaciekawieniem życiem cudzym (by się najoględniej wyrazić), tak i Ty możesz tym samym zbłądzić, więc potrzeba Ci przechodzić do porządku dziennego (wewnętrznie) nad wszystkiem, ignorować (wewnętrznie).

Teraz wracam jeszcze do Twego poprzedniego listu. Są rzeczy, które najłatwiej zademonstrować, a trudniej określić - np. wcale nie jestem zdania, że każde wyzyskanie słabych stron bliźniego jest przeciwne cnocie prostoty, ani że jest szczęśliwym określeniem dwulicowości: la duplicité, par laquelle l'homme met en avant une chose,

\footnotetext{
*[Fr.] Z wyraźnej głupoty.

*[Fr.] Masz wykluczyć ze swego umysłu wszelkie zbytnie zaprzątnięcie się tym stanem rzeczy.
} 
bien qu'il s'en propose une autre" (wysuwanie na pierwszy plan jakichś spraw, podczas gdy się zamierza właściwie dokonać innych), trzeba by tu dodać „,contraire à la première” (wręcz przeciwnych tym, które się wysuwa), bez tego jeszcze nie ma dwulicowości, bo prostota wcale nie wymaga odsłaniania całej myśli do dna - wolno mi okazać tylko jej rąbek (byle istotnie prawdziwy)".

$\mathrm{P}$ [od] d[atą] 9 V 1929 r.:

„Ze mną klapa - jadę na 2 miesiące na południe (,zmiany” w płucach, zresztą niegroźne) sam nie wiem dokładnie dokąd, bo nie nam odpowiedzi od różnych zakonnych korespondentów, gdzie będzie dla mnie miejsce. Gdy będę miał adres zagranicą przyślę Ci go".

$\mathrm{P}$ [od] d[atą] 13 VI 1929 z Rapallo ${ }^{125}$ (we Włoszech):

„Wstyd mi doprawdy, że na Twoją troskliwą dobroć dotąd odpowiedziałem milczeniem, ale byłem (i jestem jeszcze) tak wycieńczony, że nawet mówienie mnie męczyło. Najpierw, by Cię uspokoić muszę Cię zapewnić, że mi nic nie jest: temperatury nie mam (najwyższa jest $37^{\circ}$ równo, nic mnie nie boli, wyjąwszy „,wszystkie kości”, co nie jest organiczne, ale znak zmęczenia) - ale byłem tak wyczerpany anormalnym, bezdomnym, koczowniczym sposobem życia, przy rozbieżności zajęć, że w kraju nie mogłem przyjść do siebie i lekarze szczęśliwie byli tegoż zdania wysyłając mnie do Włoch, gdzie zobaczyłem po drodze Mediolan (4 dni tam spędziłem) i dotarłem tu, gdzie jestem en pension ${ }^{126}$ u ss. Urszulanek (włoskich, całkiem odrębnych od naszych i od rzymskiej unii) - dom nad samym morzem, zatoka okolona górami lesistymi, więc widok i powietrze nadzwyczajne - słońce i ciepło - mam nadzieję nauczyć się po włosku, a także dojechać do Florencji i Rzymu, a potem wrócić do Horodenki, gdzie tymczasem matka będzie stawiać piece kaflowe na probostwie i gdzie już wpłynęło 200 dolarów na fundusz odnowy kościoła. $\mathrm{Na}$ razie połykam włoskie książki (czytanie nie przedstawia żadnych trudności) i chwilami tylko żałuję tego przymusowego wyjazdu, bo musiałem odwołać 3 rekolekcje".

\footnotetext{
${ }^{125}$ Rapallo - miasto we Włoszech nad Morzem Liguryjskim niedaleko Genui, znany ośrodek turystyczno-wypoczynkowy.

${ }^{126}$ Fr.: na pensji.
} 
Florencja 14 VII 1929 r.:

„Tylko parę słów z drogi powrotnej Ci przesyłam. Rzym nie jest sympatyczny, ale raz trzeba być, żeby to widzieć (Florencja jest przemiła). Wynudziłem się we Włoszech za cały chyba czyściec i jestem najszczęśliwszy, że wracam do pracy. We Lwowie stanę 25 VII".

Korespondencja moja z ks. Adamem w dziesięciu jego ostatnich latach życia stała się rzadszą wobec tego, że od r. 1934, tj. od chwili podjęcia się przeze mnie pracy w sekretariacie J[ego] E[ekscelencji] Ks. Arcyb[iskupa] Teodorowicza, miałam z ks. Adamem kontakt nieomalże codzienny. Służył mi we wszystkim radą, dawał cenne wskazówki. Był zawsze pełen życia, werwy i apostolskiej gorliwości. W liście z 29 IX 1930 r. pisze:

„Pomyśl sobie, że spotkał mnie taki dowód uznania: Ks. Arcybiskup zaproponował mi wyjazd do Rzymu na studia. Podziękowałem pięknie, ale zawsze mi to było bardzo miłe. Staram się teraz o tytuł magistra $^{127}$, dalszych ambicji nie mam na razie, co Cię nie zdziwi skoro Ci powiem, że odnowiłem kościół bez pieniędzy, a w październiku będę dawał 10 serię rekolekcji”.

Dalej tak się wyraża o nastających, nowych czasach:

„Dziś idziemy do rozprawy z nowym duchem czasu, idącym z Ameryki i bolszewii i wszystko co się robi jest znikome w porównaniu z zadaniem przygotowania wiernych do tej walki - jeśli nie zajdzie jakiś zwrot zasadniczy w ewolucji dziejów, to nie ma wątpliwości, że do stu lat będziemy mieć ,apostasia magna" ${ }^{128}$, wobec tego, że się nic jeszcze nie robi, by wiernych wychowywać na bohaterów, sam chciałbym sto razy więcej robić: pisać, wydawać etc., ale człowiek jest skończony, czas i siły ma ograniczone, a w dodatku bez pieniędzy, ileż rzeczy jest niemożliwych”.

127 Starania o uzyskanie magisterium z teologii podjął ks. Bogdanowicz w $1931 \mathrm{r}$. W dziekanacie Wydziału Teologicznego UJK we Lwowie złożył pracę pt. „Nowsze teorie o istocie ofiary Mszy świętej”, która oceniona została pomyślnie; musiał jednak uzupełnić brakujący egzamin z patrologii, nie wiadomo jednak czy do niego podszedł i czy finalnie uzyskał tytuł magistra. T. Krzyżows ki, Archidiecezja lwowska obrządku ormiańskokatolickiego, s. 373.

128 Łac.: wielkie odstępstwo/apostazja. Jest to nawiązanie do słów zawartych w Nowym Testamencie (1 Tm 4,1; 2 Tes 2,3) mówiących o fałszywych prorokach czasów ostatecznych. 
A p [od] d[atą] 4 XI 1930 pisze co następuje:

„Zaczynam się powoli wycofywać z duszpasterstwa i pracować naukowo. Ks. Arcybiskup żąda ode mnie, bym skończył doktorat i żeby mi to ułatwić, zakazał mi przyjmować świeżych zaproszeń rekolekcyjnych, z czego już miałem okazję skorzystać 3 razy w tygodniu. Dostałem tylko dyspensę na rekolekcje dla panów, którzy mnie o to zaczęli prosić na pogrzebie Wuja Theodorowicza ${ }^{129}$ z Żukowa ${ }^{130}$ - to będzie aż w zimie. Trochę mi żal duszpasterstwa, ale biorę to jako Wolę Bożą i koniec".

Mimo całej gotowości poświęcenia pracy duszpasterskiej na rzecz dalszego kształcenia się $\mathrm{w}$ teologii, jakoś nic $\mathrm{z}$ tego nie wyszło wciąż nowe napływały urgensy ${ }^{131}$ o rekolekcje - coraz więcej dusz poddawało się jego światłemu kierownictwu. Musiał z konieczności oscylować pomiędzy pracą naukową a narzucającymi się jemu wciąż problemami duszpasterskimi. Ten stan rzeczy trwa[ł] przeszło rok. Pisze p[od] d[atą] 22 III [19]32 r.:

„Po tym W[ielkim] Poście jestem prawie zdecydowany ostatecznie wyrzec się kariery naukowej na uniwersytecie, a oddać się całkowicie pracy duszpasterskiej przez rekolekcje i indywidualne kierownictwo, a o ile zmogę i przez pisarstwo. Zaczyna mi się ta droga ostatecznie ustalać jako Wola Boża. Co o tym sądzisz?"

30 XII [19]32 r. pisze co następuje:

„Życz mi czego chcesz tylko nie doktoratu, bo o tym teraz już mowy być nie może. Definitywnie rozstaję się już z tą myślą i z tą perspektywą, bo nie ma gdzie szpilki wetknąć w moje życie, takie jakiem je Opatrzność uczyniła".

Trwając w przeświadczeniu, że to Opatrzność Boża taką mu drogę wytknęła, rozwijał przez dalszych kilka lat swą wspaniałą pracę dusz-

129 Antoni Wincenty Theodorowicz (Teodorowicz; 1852-1930) - ur. w miejscowości Michalicze na Pokuciu w rodzinie ormiańskiej Teodora i Kajetany z Bohdanowiczów; ziemianin, właściciel Żukowa i Korszowa, poseł do Sejmu Krajowego Galicyjskiego we Lwowie (1895-1914) wybrany z IV kurii okręgu Horodenka, marszałek Rady Powiatowej w Horodence, członek Komitetu Parafialnego parafii ormiańskiej w Horodence. Kronika Pokucka, „Goniec Pokucki”, 1907, nr 40, s. 4; S. Gro d z i s k i, Sejm Krajowy Galicyjski 1861-1914, Kraków 2018, s. 398, 405, 413, 421, 612?

130 Żuków - wieś w województwie stanisławowskim oddalona ok. $30 \mathrm{~km}$ na zachód od Horodenki, obecnie na Ukrainie

${ }^{131}$ Dawniej: pisemne ponaglenia. 
pasterską, poświęcając się bez reszty ratowaniu dusz Krwią Chrystusową odkupionych.

Nie brak mu było przeciwności, nawet przykrych zajść - Chrystus kładł pieczęć swoich cierpień na zbożnych jego poczynaniach. Będąc od Boga obdarzonym niezwykle uzdolnionym umysłem, mając głowę otwartą na grożące duszom niebezpieczeństwa, przeczuwając przy tym całą grozę zbliżającej się od wschodu pożogi - nie przestał bić na alarm. Szokował tym swoich konfratrów ${ }^{132}$ bardziej krótkowzrocznych, a nawet i hierarchię, która raz po raz wnosiła zażalenia przed trybunał Ks. Arcyb[iskupa] Teodorowicza, zwłaszcza w odniesieniu do jego prelekcji i nauk rekolekcyjnych. Wydał bowiem nieubłagalną walkę przeciwko szerzącemu się coraz bardziej wśród społeczeństwa grzechowi dzieciobójstwa.

Bez ogródek grzech ten piętnował mówiąc o nim otwarcie na rekolekcjach dla młodzieży kończącej szkoły, dawał rady i starał się zapobiec tym coraz liczniejszym, rodzącym się w społeczeństwie nowym możliwościom grzęźnięcia w tym grzechu. Dziś inaczej - w obliczu jawnego niebezpieczeństwa mówi się o tym $\mathrm{z}$ ambony. Wtedy poruszanie tych kwestii ograniczało się jedynie do konfesjonału. Liczne więc skargi na śmiałość ks. Bogdanowicza napływały do Kurii Arcybiskupa ormiańskiego i to nawet ze strony czołowych osobistości w Kościele ${ }^{133}$.

\footnotetext{
132 Łac.: współbraci.

${ }^{133}$ Ks. Bogdanowicz podczas konferencji i rozmów w ramach kierownictwa duchowego, jakie prowadził poruszał zagadnienia istotne zwłaszcza dla młodzieży wkraczającej w dorosłe życie. Mówił o czystości przedmałżeńskiej i małżeńskiej, antykoncepcji, planowaniu rodziny, co wówczas zwłaszcza dla starszego pokolenia uznawane było za niestosowne i wzbudzało kontrowersje. Penitentka ks. Bogdanowicza Helena Mycielska wspominała po latach: „Świeccy natomiast, a zwłaszcza pobożne panie, nie mogły mu darować, że miesza się do spraw pożycia małżeńskiego od jego intymnej strony. Twierdziły, że księża, a jeszcze do tego młodzi, nie mają tu nic do gadania. Odsądzano go niemal od czci i wiary. Zarzucano, że gorszy młode panien[ki] pouczając je, jak mają postępować w przyszłości, by planować ilość dzieci. Chodziło o niedawno odkrytą metodę regulowania poczęć Ogino-Knaus, zgodną z biologią i katolickim sumieniem". AFKiDOP, b.sygn., H. Mycielska, Wspomnienie o ks. Adamie Bogdanowiczu, Kraków 1983, mps, s. 2. Kolejnym zagadnieniem wzbudzającym dyskusje była propagowana przez ks. Bogdanowicza pobożność liturgiczna, o czym nadmieniono już wyżej. W myśl dekretu Piusa X Sacra Tridentina Synodus z 1905 r. zachęcał on wiernych do częstego przyjmowania Komunii św. i wydał w tym celu osobną broszurę (Częsta Komunia św. a częstość spowiedzi wiernych $w$ praktyce duszpasterskiej, Lwów 1938). Wobec narastającej krytyki i oskarżeń o głoszenie
} 
Ks. Arcybiskup Teodorowicz sam przestrzegał go, prosił i napominał, by tego w tak ostrej formie nie czynił ${ }^{134}$. On jednak obdarzony tą swoją wyjątkową dalekowzrocznością, dotykając się w tym swoim szeroko zakrojonym duszpasterstwie, tych groźnych ran - nie mógł się po prostu powstrzymać od bicia na alarm.

Mianowany w końcu kanonikiem kapituły katedralnej, gdy pożegnał probostwo w Horodence, cały się oddał duszpasterstwu, zrezygnowawszy z dalszych studiów teologicznych i możliwości osiągnięcia stopni naukowych.

Gdy po śmierci śp. Ks. Arcybiskupa Teodorowicza (+4 XII 1938 r.) oczekiwano wybory nowego Arcypasterza diecezji ormiańskiej, oczy wszystkich zwrócone były na ks. Bogdanowicza.

Nagły wybuch wojny (1 IX 1939 r.) stał się poważną przeszkodą w zabiegach Ormian o obsadzenie osieroconej stolicy swego arcybiskupstwa. Pozostał vacat, którego po skończonej już wojnie trudno było obsadzić wobec dotkliwych strat jakie poniosła archidiecezja w ciągu pięcioletniego trwania okupacji i zmagań $\mathrm{z}$ wrogiem ${ }^{135}$ : ks. Bogdanowicz

poglądów sprzecznych z doktryną Kościoła katolickiego ks. Bogdanowicz zwrócił się do Nuncjatury Apostolskiej w Warszawie z obszernym wyjaśnieniem podejmując zarazem próbę walki o swoje dobre imię. Odważnie formułowane poglądy kapłana nie wzbudziły najwyraźniej zastrzeżeń ze strony władz kościelnych, gdyż nie otrzymał on żadnych ograniczeń bądź zakazów w kwestii swobodnej wypowiedzi. Archivio Apostolico Vaticano, Arch. Nunz. Varsavia 273, fasc. 1134, Pismo ks. Adama Bogdanowicza do ks. Alfredo Paciniego, Kossów 16 V 1936, k. 98r-106r. T. K r z y ż o w s k i, Korespondencja arcybiskupa ormiańskokatolickiego Józefa Teodorowicza z Prymasem Polski kardynatem Augustem Hlondem z lat 1924-1938, „Lehahayer. Czasopismo Poświęcone Dziejom Ormian Polskich", 2019, nr 6, s. 279-280.

134 Abp Teodorowicz w liście do abp. Adama Stefana Sapiehy z 20 VII 1929 r. na temat ks. Bogdanowicza pisał: „Z różnych stron mi mówią, że ma doskonale spowiadać i prowadzić. Ja mam wprawdzie pewne zastrzeżenia, co do jego mistycznego prowadzenia panienek z Sacré Coeur, ale u osób dojrzałych może być dobry. W każdym razie sam bardzo wewnętrzne życie prowadzi”. J. W o ł c z a ń s k i, Korespondencja abp. Józefa Teodorowicza z abp. Adamem Stefanem Sapieha z lat 1901-1938, [w:] Arcybiskup Józef Teodorowicz (1864-1938). Studia i materiaty, red. J. W o 1 c z a ń s k i, Kraków 2017, s. 374.

135 W wyniku działań wojennych i włączenia Kresów Południowo-wschodnich do Związku Sowieckiego struktury archidiecezji ormiańskiej we Lwowie przestały istnieć, kapłani i wierni zostali w większości ekspatriowani w granice Polski powojennej lub zesłani do łagrów, świątynie i dziedzictwo kulturalne uległo zniszczeniu i rozproszeniu, co oznaczało faktyczną likwidację archidiecezji. J. S m i r n o w, Das Schicksal der armenisch-katholischen Kirche in Galizien während des zweiten Weltkriegs 
zginął w więzieniu, ks. Agopsowicz ${ }^{136}$ zastrzelony został w Kutach, kiedy przechodził przez granicę. Inni jak ks. Kajetanowicz ${ }^{137}$, wikariusz generalny kapituły ormiańskiej ${ }^{138}$ i ks. Romaszkan ${ }^{139}$ wywie-

und in der Nachkriegszeit, „Resovia Sacra. Studia Teologiczno-Filozoficzne Diecezji Rzeszowskiej”, 2007/2008, nr 14-15, s. 221-239.

136 Bogdan Agopsowicz (1908-1940), ur. w rodzinie ormiańskiej, w 1936 r. przyjąl święcenia kapłańskie i został wikariuszem katedry ormiańskiej we Lwowie, wychowawcą w Zakładzie Naukowym im. Józefa Torosiewicza, bibliotekarzem Kurii oraz dyrektorem Archidiecezjalnego Muzeum Ormiańskiego. W czasie II wojny światowej zaangażował się $\mathrm{w}$ działalność konspiracyjną, został zastrzelony przez żołnierzy sowieckich podczas przekraczania granicy z Rumunią na rzece Czeremosz. T. Z a 1 e s k i, Stownik biograficzny, s. 24.

${ }^{137}$ Dionizy Kajetanowicz (1878-1954), ur. w rodzinie ormiańskiej, w 1896 r. wstąpił do Zakonu Braci Mniejszych (reformatów) w Krakowie, w 1903 r. przyjął święcenia kapłańskie. Pracował duszpastersko w Krakowie i Jarosławiu. W 1908 r. opuścił zakon i został inkardynowany do lwowskiej archidiecezji ormiańskiej, w której sprawował posługę wikariusza katedry ormiańskiej i prefekta Zakładu Naukowego im. Józefa Torosiewicza we Lwowie (1908-1911), a następnie proboszcza parafii ormiańskiej w Śniatynie (1911-1922). W 1922 r. mianowany kanonikiem gremialnym kapituły ormiańskiej we Lwowie, w 1923 r. kanclerzem kurii i proboszczem parafii katedralnej, w 1933 r. został prepozytem kapituły. Po śmierci abp. Józefa Teodorowicza w 1938 r. został rządcą archidiecezji ormiańskiej. W czasie II wojny światowej zaangażował się w akcję ratowania Żydów wystawiając im fałszywe metryki chrzcielne. 8 III 1946 r. został skazany przez władze sowieckie na 10 lat łagrów. Zmarł w łagrze Abieź w republice Komi w 1954 r. Był autorem prac z historii Ormian polskich oraz thumaczeń pieśni liturgicznych z języka ormiańskiego, współzałożyciel pierwszego czasopisma Ormian polskich „Posłaniec św. Grzegorza” (1927) oraz Archidiecezjalnego Związku Ormian (1930). W 2009 r. przedstawiciele środowiska ormiańskiego w Polsce podjęli starania o wszczęcie procesu beatyfikacyjnego ks. Kajetanowicza jako męczennika za wiarę, nie przynosiły one jednak spodziewanego rezultatu. T. Krzyżowski, Archidiecezja lwowska obrzadku ormiańskokatolickiego, s. 16, 39, 46, 52-53, 59, 61, 63, 66-68, 70, 76, 86, 94, 96, 109-110, 112-113, 115, 136, 139, 140, 143, 158-160, 172, 174, 179, 184, 186, 188-189, 199-204, 216, 220-221, 231, 251, 259, 265, 280-281, 289, 291, 299, 312-313, $315-316,325,329-330,332,350,352,354,358,366,368$, 382, 393, 405, 409, 414-419, $430,432,444,446,448-451,455,457,459,469-470,474,502,505,520,535-537$, 539-540, 544-545, 549-552, 555-556, 559-560, 568, 571-572, 576-577, 589-590; J. W ołc zański, Martyrologium księży ormiańskokatolickich $w$ archidiecezji lwowskiej po II wojnie światowej w świetle źródet sowieckich, [w:] Polacy w Armenii, red. E. W a le w a n d e r, Lublin 2000, s. 193-219.

${ }^{138} \mathrm{Ks}$. Kajetanowicz był wikariuszem kapitulnym.

${ }^{139}$ Kazimierz Romaszkan (1909-1973), ur. w rodzinie ormiańskiej, absolwent Papieskiego Kolegium Ormiańskiego w Rzymie i Uniwersytetu Gregoriańskiego (1928-1935), w 1935 r. przyjął święcenia kapłańskie i wrócił do Polski, był wikariuszem parafii we Lwowie i Stanisławowie, katechetą w szkole żeńskiej benedyktynek ormiańskich 
zieni zostali w głąb Rosji. Ks. Kirmizjan ${ }^{140}$ i ks. Gawroński ${ }^{141}$ uszli do Rzymu, ks. Eugulian ${ }^{142}$ utonął w Styrpie ${ }^{143}$, ks. Isakowicz ${ }^{144}$ zmarł $^{145}$ nagle 2 V 1944 r. w Stanisławowie ${ }^{145}$.

i notariuszem Kurii ormiańskiej. W czasie II wojny światowej zaangażowany w działalność niepodległościową i ratowanie Żydów, 8 III 1946 r. skazany przez władze sowieckie na 15 lat więzienia. Karę odbył w łagrze w Norylsku na Syberii, w 1955 r. został zwolniony, przyjechał do Polski i podjął pracę duszpasterską w archidiecezji wrocławskiej. Od 1966 r. prowadził duszpasterstwo dla Ormian katolików w kościele pw. Św. Trójcy w Gliwicach. T. K r z y ż o w s k i, Archidiecezja lwowska obrzadku ormiańskokatolickiego, s. 52, 106, 174, 240, 251, 253-254, 291-295, 297, 301-302, 351, 544, 585; J. W o ł c z a ń s k i, Martyrologium księży ormiańskokatolickich, s. 193-219. 140 Bohos Kirmizjan (1874-1952), ur. w rodzinie ormiańskiej w Brussie (Turcja), absolwent Papieskiego Kolegium Ormiańskiego w Rzymie, w 1897 r. przyjął święcenia kapłańskie, w latach 1906-1939 pracował w lwowskiej archidiecezji ormiańskiej jako wikariusz parafii we Lwowie i Kutach oraz dyrektor banku Mons Pius, kapelan benedyktynek ormiańskich i sekretarz abp. J. Teodorowicza, należał do grona założycieli Archidiecezjalnego Związku Ormian. W 1939 r. opuścił Polskę i osiadł w Rzymie. T. K r z y ż o w s k i, Archidiecezja lwowska obrzadku ormiańskokatolickiego, s. 52, 95, 172, 188-189, 221, 251, 319, 322, 326, 340, 393, 416-417, 419, 444; T. Z a l e s k i, Słownik biograficzny, s. 62.

141 German Gawroński (1897-1955), ur. w rodzinie rzymskokatolickiej, w 1925 r. inkardynowany przez abp. J. Teodorowicza do lwowskiej archidiecezji ormiańskiej, w 1928 r. przyjął święcenia kapłańskie. Był wikariuszem katedry we Lwowie i moderatorem działających przy niej bractw religijnych oraz katechetą. Okres II wojny światowej spędził w Rzymie, po wojnie wrócił do Polski i podjął pracę duszpasterską w archidiecezji wrocławskiej, był m.in. proboszczem w Ścinawce Średniej. T. K r z y ż o w s k i, Archidiecezja lwowska obrządku ormiańskokatolickiego, s. 52, 67, 113, 274, 349, 393, 289-290, 300, 354, 459, 521, 572, 576, 586, 590; T. Z a l e s k i, Słownik biograficzny, s. 47.

142 Sarkis Egulian (1906-1944), ur. w Adanie (Turcja) w rodzinie ormiańskiej, absolwent Papieskiego Kolegium Ormiańskiego w Rzymie, dr teologii, w 1931 r. przyjął święcenia kapłańskie i został skierowany do pracy duszpasterskiej w lwowskiej archidiecezji ormiańskiej. Był wikariuszem parafii we Lwowie (1931-1932) i Stanisławowie (1932-1938) oraz administratorem parafii w Brzeżanach (1938-1944). T. K r z y ż o w s k i, Archidiecezja lwowska obrządku ormiańskokatolickiego, s. 52, 79, 83, 94, 106, 320, 322, 326, 374, 444, 451, 509, 576, 585.

143 Strypa - lewy dopływ rzeki Dniestr.

${ }^{144}$ Leon Isakowicz (1897-1944), ur. w rodzinie ormiańskiej, święcenia kapłańskie przyjął w 1919 r. i został wikariuszem katedry ormiańskiej we Lwowie. Ponadto był notariuszem Kurii Arcybiskupiej obrządku ormiańskiego, pracownikiem Sądu Arcybiskupiego, katechetą w Gimnazjum Żeńskim Sióstr Nazaretanek oraz asystentem w katedrze Sztuki Sakralnej na Wydziale Teologicznym Uniwersytetu Jana Kazimierza we Lwowie (19201922). W 1930 r. został kanonikiem gremialnym kapituły ormiańskiej we Lwowie. Należał do grona organizatorów Wystawy Zabytków Ormiańskich we Lwowie 
Po ks. Bogdanowicza przyszli wysłańcy NKWD, jak to bywa u nich we zwyczaju, w nocy z 1 IV na 2 IV 1940 r. Najpierw uprowadzili z jego mieszkania (we Lwowie przy ul. Skarbkowskiej 12) jego siostrę cioteczną pania $\mathrm{M}$ [arię] $\mathrm{E}$ [azarską ${ }^{146}$, która wraz $\mathrm{z}$ trojgiem swoich małych dzieci ${ }^{147}$ (w wieku 10, 9 i 7 lat) schroniła się była do matki księdza, po przejściu swego męża ${ }^{148}$ do Francji do walczącej tam polskiej armii.

Nad dalszym losem tych obu zapadła od razu żelazna kurtyna. Nigdy żadna wiadomości o nich nie dotarła do najbliższych. Paczki, które się podawało dla nich u bramy więzienia „Brygidek” na Kazi-

w 1932 r. W 1936 r. mianowany administratorem parafii ormiańskiej w Stanisławowie, którą kierował do śmierci. Przygotował koronację cudownego wizerunku Matki Bożej Łaskawej w Stanisławowie (30 V 1937), w 1938 r. obdarzony godnością tajnego szambelana papieskiego. T. K r z y żow s k i, Archidiecezja lwowska obrzadku ormiańskokatolickiego, s. 50, 52, 70, 106, 123, 172, 183-184, 186, 188-189, 201-204, $225,270,280,300,331-332$, 338, 348-349, 352, 354-358, 360, 368-369, 430, 451, 487, 505, 510, 521, 534, 544-545, 565-566, 568-569, 572, 576, 581, 594.

145 Stanisławów - miasto wojewódzkie Małopolsce Wschodniej, znajdowała się tam parafia obrządku ormiańskiego pw. Niepokalanego Poczęcia NMP; obecnie miasto Iwanofrankiwsk na Ukrainie.

146 Maria Łazarska z d. Bohdanowicz de Oroszeny (1897-1988), ur. w Czerniowcach w rodzinie ormiańskiej Kazimierza i Stefanii z Ohanowiczów, działała w Sodalicji Marjańskiej, w 1929 r. wyszła za mąż za Edgara Łazarskiego i zamieszkała w Mościcach k. Tarnowa. Po wybuchu II wojny światowej przeniosła się z rodziną do Lwowa. Aresztowana przez NKWD z 1 na 2 IV 1940 r. i osadzona w więzieniu „Brygidki”, w 1941 r. wywieziona do Kazachstanu, gdzie pracowała jako opiekunka w sierocińcu. Próbowała uczyć dzieci religii za co została ukarana i osadzona w więzieniu. W 1945 r. w wyniku amnestii zwolniona wróciła do Polski i zamieszkała w Mościcach, a od 1964 r. w Krakowie. Pracowała w sklepie, w fabryce oraz w bibliotece. Pochowana na cmentarzu w Batowicach. Relacja ustna Stanisława Łazarskiego, Kraków 14 IX 2020 r.

147 Byli to: Stanisław Łazarski (ur. 1929), Eustachy Łazarski (1931-2014), i Aleksander Łazarski (1932-1993).

148 Edgar Lazarski (1888-1942), syn Stanisława adwokata i polityka i Marty Szermańskiej, prawnik, po ukończeniu studiów pracował w banku, po wybuchu I wojny światowej służył w kawalerii w Armii Austro-Węgierskiej, mjr 8 Pułku Ułanów Księcia Józefa Poniatowskiego, następnie w stanie spoczynku. Przed II wojną światową kierował ochroną w Fabryce Związków Azotowych w Mościcach, w 1939 r. walczył w obronie Lwowa jako ochotnik, po zajęciu miasta przez Sowietów w 1941 r. przedostał się wraz z grupą żołnierzy przez zieloną granicę do Francji. W Paryżu włączył się w działalność konspiracyjną, planował wyjazd do Anglii, jednak został zatrzymany i osadzony w Compiègne. Dalsze losy nieznane, prawdopodobnie zmarł w 1942 r. Relacja ustna Stanisława Łazarskiego, Kraków 14 IX 2020 r. 
mierzowskiej ${ }^{149}$ zawsze były przyjmowane, ale czy cokolwiek z tego doszło do ich rąk pozostało znakiem zapytania. Skąpe tylko szczegóły podawane przez osoby trzecie przesączały się na zewnątrz, budząc zawsze niepokój i podejrzenie. I tak doszło nas, że p[ani] M[aria] Ł[azarska] była śledzona od chwili, gdy jej mąż przedarł się przez zieloną granicę (na Węgry). Ks. Bogdanowicza zaś miał zadenuncjować jeden z członków „Iuventus Christiana" "150 nasłany do tegoż zrzeszenia młodzieżowego w charakterze wtyczki. Ksiądz gromadził dookoła siebie młodzież z „Iuventus'u”, pouczał ją, kierował nią i w miarę potrzeby udzielał nawet uboższym jej członkom wsparcia materialnego zaczerpniętego $\mathrm{z}$ datków, które na ten cel zbierał ${ }^{151}$. Na skutek tej akcji został oskarżony o wykroczenie przeciw Konstytucji ZSRR § 54 a): zdrada stanu $^{152}$. Wytoczono mu w więzieniu śledztwo, podczas którego okrutnie go torturowano, żeby wymóc na nim potrzebne zeznania. Ilekroć

${ }^{149}$ Więzienie we Lwowie w dawnym klasztorze brygidek, w okresie II wojny światowej miejsce masowych egzekucji dokonywanych przez NKWD.

150 Juventus Christiana - stowarzyszenie katolickiej młodzieży akademickiej zorganizowane w 1921 r. w Warszawie z inicjatywy ks. Edwarda Szwejnica. Jego działalność skupiała się na rozwoju religijnym członków poprzez rozważanie Pisma św. w koedukacyjnych grupach pod kierunkiem moderatora. Funkcjonowało w kilku miastach akademickich, m.in. Warszawie, Poznaniu, Wilnie i Lwowie. Przed II wojną światową najliczniejsza katolicka organizacja akademicka w Polsce; w okresie wojny działała w konspiracji, zlikwidowana przez władze komunistyczne w 1949 r. S. G a j e w s k i, Iuventus Christiana, [w:] EK, t. 7, red. J. D u c h n i e w s k i, Lublin 1997, kol. 564-566. ${ }^{151}$ Faktycznym powodem aresztowania była działalność konspiracyjna ks. Bogdanowicza w Związku Walki Zbrojnej. Należał on wraz z ks. Józefem Panasiem i Zygmuntem Chrząstowskim do Komisji Skarbowej. Sprawowała ona pieczę nad złotem i kosztownościami przywiezionymi z poznańskiego lombardu do Lwowa w 1939 r., przekazanymi w styczniu 1940 r. do dyspozycji ZWZ. Złoto i precjoza sprzedawano na czarnym rynku, a uzyskane fundusze przekazywano na działalność organizacji. W marcu i kwietniu 1940 r. NKWD dokonało szeregu aresztowań członków organizacji, w tym ks. Bogdanowicza. R. W n u k, „Za pierwszego Sowieta”. Polska konspiracja na Kresach Wschodnich II Rzeczypospolitej (wrzesień 1939-czerwiec 1941), Warszawa 2007, s. $55,85-86$.

${ }^{152}$ Ks. Bogdanowicz został oskarżony: „o to, że był aktywnym członkiem organizacji kontrrewolucyjnej, przyjmował przyjeżdżających zza granicy kurierów i kontaktował ich z kierownikami organizacji kontrrewolucyjnej; zdobywał środki na kontrrewolucyjne potrzeby organizacji i osobiście udzielał wsparcia materialnego członkom organizacji kontrrewolucyjnej, tj. o przestępstwo z art. art. 54-2, 54-11 KK USRS". Polska i Ukraina $w$ latach trzydziestych-czterdziestych XX wieku. Nieznane dokumenty $z$ archiwów stużb specjalnych. Polskie Podziemie 1939-1941, t. 1: Lwów-Kołomyja, StryjZłoczów, red. Z. G a j o w n i c z e k, Warszawa-Kijów 1998, s. 697. 
odprowadzano go z tych nocnych posiedzeń do celi, żałosne jęki dawały się słyszeć dookoła. Nastąpił proces, po zakończeniu, którego otrzymał w dniu 8 XII 1940 r. wyrok śmierci. Wniósł apelację do Stalina $^{153}$ i na wiosnę 1941 r. otrzymał zamianę kary śmierci na 16 lat ciężkiego więzienia $^{154}$ - zaś M[aria] Ł[azarska] cioteczna jego siostra w tym samym mniej więcej czasie wywiezioną została wraz z innymi więźniarkami na Sybir, skąd powróciła w r. $1946^{155}$. Tyle dotarło do nas wówczas zza żelaznej kurtyny więziennej. Ogromnie przejęci tym wszystkim przemyśliwaliśmy nieustannie nad tym, co by można uczynić dla ratowania tych biednych skazańców.

Pamiętam, że mi się wówczas przydarzyło coś, co by chyba należało zaliczyć do telepatycznych doznań psychicznych. Pracowałam wtedy

153 Józef Stalin (1878-1953) - właściwie: Iosif Dżugaszwili, ur. w Gruzji, od 1898 r. związany z socjaldemokracją, w 1903 r. wstąpił do partii bolszewickiej, w 1912 r. wybrany do Komitetu Centralnego, należał do redakcji „Prawdy”. Współorganizator rewolucji październikowej w 1917 r., członek Biura Politycznego Komunistycznej Partii Związku Radzieckiego (1919-1953), sekretarz generalny KPZR (1922-1953) przejął kontrolę nad partią i państwem stając się dyktatorem. Odpowiedzialny za kolektywizację, która pochłonęła miliony ofiar oraz masowy terror i czystki przeciwników politycznych. Przyczynił się do wybuchu II wojny światowej, przewodniczący Rady Komisarzy Ludowych ZSRR (1941-1946), przewodniczący Rady Ministrów ZSRR (1946-1953), Ludowy Komisarz Obrony (1941-1946). Uczestniczył w konferencjach pokojowych w Teheranie (1943) oraz w Jałcie i Poczdamie (1945), wpłynął na narzucenie krajom Europy Środkowo-Wschodniej ustroju komunistycznego. Stalin Józef, [w:] Rosja, red. W. S i e n k i e w i c z, Warszawa 2001, s. 243-244.

154 Błąd autorki; podana przez nią data wydania wyroku śmierci oraz zamiany tegoż na karę więzienia nie znajdują odzwierciedlenia w materiale źródłowym. Wyrok skazujący ks. Bogdanowicza wraz z 12 pozostałymi działaczami ZWZ w tzw. ,procesie czternastu" na karę śmierci przez rozstrzelanie i konfiskatę mienia na rzecz skarbu państwa wydał Lwowski Sąd Obwodowy 19-20 XI 1940 r. Oskarżeni wnieśli prośbę o ułaskawienie do Prezydium Rady Najwyższej ZSRR, która 15 II 1941 r. utrzymała w mocy wydany uprzednio wyrok. Dokumenty procesowe podają, że wyrok został wykonany 24 II 1941 r. Według relacji świadków (zob. niżej) ks. Bogdanowicz przebywał nadal w więzieniu „Brygidki” i zginął 24 VI 1941 r. podczas ewakuacji więźniów. Szczegóły dotyczące procesu i wyroku zob.: Polska $i$ Ukraina $w$ latach trzydziestych-czterdziestych XX wieku, s. 677-765; E. K ot a r s k aroces czternastu, Warszawa 1998, s. 8, 11, 40-43, 45, 46, 49, 74-75, 114-115, 117, 119, 121-125, 128, 177, 238-241, 246, 257-259, 265, 267.

155 Maria Łazarska wróciła do Polski w 1945 r., gdzie w Rabce spotkała się ze swoimi synami, którymi opiekowali się krewni. 
w klinice chirurgicznej Prof. T. Ostrowskiego ${ }^{156}$ przy ul. Pijarów 4. Pełniłam nocne dyżury. Podczas jednego z tych dyżurów, w oczekiwaniu na dzwonki od chorych, zdrzemnęłam się i usłyszałam nagle wyraźny i donośny głos ks. Bogdanowicza: „Ciało moje pod płonącą belką". Nie umiałam sobie absolutnie wytłumaczyć, co to ma znaczyć? Czy to jakaś alegoria, czy rzeczywisty stan rzeczy, a może zawiadomienie o śmierci? Dopiero w rok potem skojarzyło mi się to [z] wieściami tragicznymi, które mnie doszły (o czym p[atrz] niżej).

Wciąż wysilałam umysł w tym jednym kierunku: jakby to można ratować ks. B[ogdanowicza]? Przyszło mi wtedy na myśl, że trzeba by udać się do Ks. Metropolity Szeptyckiego ${ }^{157}$ i jego prosić o interwencję. Może wreszcie tak wybitnej osobistości uda się coś uzyskać? Udałam się więc pewnego poranka wprost z dyżuru do Pałacu Arcybiskupiego na plac św. Jura i stanęła w długiej kolejce petentów czekających na audiencję. Za każdym razem, gdy drzwi się otwierały i jedni wchodzili a drudzy wychodzili, ukazywała się siwa głowa pochylonego nad grubą księgą sędziwego Metropolity, wyglądał zupełnie podobnie do obrazu Dawida pędzla Rembrandta ${ }^{158}$ - nastrój dookoła był nader podniosły i nacechowany skupieniem. Kiedy dotarłam wreszcie do celu i przedstawiłam swoją sprawę Ks. Metropolicie, odrzekł mi bardzo niemile zdziwiony: „Za kogo mnie Pani właściwie ma, że mi pani przypisuje możliwość ingerencji w takie sprawy? Przecież ja nawet nic uczynić nie mogę dla ratowania mego bratanka Jasia ${ }^{159}$,

156 Tadeusz Ostrowski (1881-1941) - studia medyczne ukończył w Warszawie i Kazaniu, asystent prof. Ludwika Rydygiera, od 1923 r. profesor chirurgii na Wydziale Lekarskim Uniwersytetu Jana Kazimierza we Lwowie, dziekan tegoż wydziału (1937/38), kierownik Kliniki Chirurgicznej, prekursor nowatorskich operacji i metod leczenia, członek Międzynarodowego Towarzystwa Urologicznego i in. Z zamiłowania taternik i kolekcjoner dzieł sztuki. Został zamordowany wraz z żoną i innymi profesorami przez Niemców w nocy z 3 na 4 VII 1941 r. D. Ne s piak, Tadeusz. Ostrowski, ,Wrocławskie Studia Wschodnie”, 2018, t. 22, s. 253-267.

157 Andrzej Szeptycki (1865-1944), święcenia kapłańskie w obrządku greckokatolickim przyjął w 1892 r. w Przemyślu, ordynariusz unickiej diecezji stanisławowskiej (1899-1900), arcybiskup-metropolita lwowski obrządku greckokatolickiego (1900-1944), Sługa Boży Kościoła katolickiego. Metropolita Andrzej Szeptycki. Studia i materiały, red. A. A. Zi ę b a, Kraków 1994, passim.

158 Rembrandt Harmenszoon van Rijn (1606-1669) - światowej sławy holenderski malarz, grafik i rysownik.

159 Jan Leon Szeptycki (1905-1980), syn Leona Szeptyckiego, brata Andrzeja, arystokrata, ziemianin, właściciel majątku Dziewiętniki, w młodości zaangażowany w działal- 
który odsiaduje więzienie od samego początku wojny!" Przeprosiłam Ks. Metropolitę za moją śmiałość, a zarazem prosiłam, by zechciał zrozumieć, że się chce kogoś ratować, to człowiek już się na nic nie ogląda i jak tonący chwyta się brzytwy. A może pan dr Pańczyszyn ${ }^{160}$ potrafi coś w tym względzie uczynić?

Tak rozumowałam na podstawie tego, że Sowieci początkowo darzyli tego skądinąd znakomitego internistę ukraińskiego dużymi względami. Ale i na to odrzekł mi Ks. Metropolita z powagą: „Skądże by on miał jakieś wpływy?"

Odeszłam więc z niczym - pozostała mi jedna modlitwa do Boga o łaskę i zmiłowanie dla ks. Bogdanowicza i dla biednej jego matki. Udręka przez którą ona przechodziła nie da się opisać. Dla względów bezpieczeństwa musiała opuścić dotychczasową swoją siedzibę opodal katedry orm[iańskiej] i tułać się z miejsca na miejsce. Każdy dzień, w którym brakło u jej boku ukochanego syna, był dla niej źródłem nowych niepokojów. Myśli jej bez przestanku obracały się dookoła jego osoby. „Jak on tam znosi te upały” pytała, ,pewno siedzi ledwo żywy w tym zaduchu”. Raz wymknęło jej się takie słowo: „Ja go pewno już nie zobaczę. Czuję, Bóg żąda ode mnie tej ofiary!" Niemniej ilekroć się gdzieś przeprowadzała, zawsze kazała dorabiać drugie klucze do mieszkania „dla Adasia”. Słowem przez tę męczeńską nowennę lat, jakie jej

ność stowarzyszeń katolickich („Odrodzenie”, Sodalicja Marjańska), dr prawa na Uniwersytecie Jana Kazimierza we Lwowie, działacz społeczny. W 1934 r. ożenił się z Zofią Olgą z Wielopolskich, z którą miał 3 dzieci. W 1939 r. aresztowany przez Sowietów i osadzony we Lwowie, Kijowie, Charkowie, a następnie zesłany do łagru, z którego wydostał się dzięki amnestii. Walczył w armii gen. Władysława Andersa, m.in. pod Monte Casino, po II wojnie światowej osiadł z rodziną w RPA. A. S z e p t y c k a, P. S. Łoś, Szeptycki Jan Leon Sylwester, [w:] Ziemianie polscy XX wieku. Stownik biograficzny, cz. 7, red. J. L e s k i e w i c z o w a, Warszawa 2004, s. 154-156. ${ }^{160}$ Marian Panczyszyn (1882-1943) - ukraiński lekarz i działacz polityczny, absolwent Wydziału Lekarskiego Uniwersytetu Lwowskiego (1909), pracownik lwowskich szpitali, m.in. Kliniki Chorób Wewnętrznych, rektor Tajnego Uniwersytetu Ukraińskiego (1924-1925), minister zdrowia w ukraińskim rządzie Jarosława Stećki (1941), członek Ukraińskiej Rady Narodowej (1941-1942), komisaryczny zarządca Wydziału Lekarskiego (1941), osobisty lekarz abp. Szeptyckiego, w 1943 r. ukrywał się w jego rezydencji, gdzie zmarł na zawał serca. Z. Albert, Lwowski Wydziat Lekarski w czasie okupacji hitlerowskiej 1941-1944, Wrocław 1975, passim; Р. О с і н ь ч у к, Паньчишин Маріян, [w:] Енциклопедія украӥнознавства. Словникова частина, т. 5, ред. В. Кубійович, Париж-Нью-Йорк 1966, s. 1940. 
jeszcze do życia pozostawały, żyła na przemian to nadzieją, że on jeszcze powróci, to przeczuciem, że go tu na ziemi już nie zobaczy.

W międzyczasie zaszło coś, czego nawet najdociekliwszy umysł nigdy nie byłby przypuścił, czego nikt $\mathrm{z}$ nas się nie spodziewał: Niemcy wydali wojnę Sowietom.

Pamiętam znów jeden znamienny szczegół, o którym chciałabym tu wspomnieć. Był r[ok] 1941, maj, dzień Wniebowstąpienia Pańskiego. Leżałam chora na zapalenie płuc, odwiedził mnie jeden znajomy. Byliśmy do głębi przejęci drugim wywozem na Sybir, który w dniu tym miał miejsce. Niektóre szczegóły z pierwszego wywozu (w lutym tegoż roku) jeszcze żywo stały w pamięci, a tu znów przyszła kolej na drugą podobną makabrę.

„Do trzeciego wywozu, zaplanowanego na czerwiec już nie dojdzie” - uspokajał mnie mój znajomy - „bo tymi pociągami, którymi na cel ten podstawią Sowieci, sami będą zmuszeni ewakuować swoich ludzi stąd, bo wtedy właśnie wybuchnie wojna Niemców ze Związkiem Radzieckim!"

Wydawało mi się to rzeczą tak nieprawdopodobną, że mu wprost zaprzeczyłam i zarazem zapytałam, skąd on z taką pewnością może coś podobnego twierdzić? A on mi na to: „Matka Boska objawiła to pewnemu pobożnemu młodzieńcowi, gdy ten gorąco się do Niej modlił w jednej z kapliczek przydrożnych". Przekonałam się o prawdzie tej przepowiedni, gdy w parę tygodni po tym to wszystko na oczach naszych z precyzyjną dokładnością się spełniło.

Nie zapomnę tej nocy sobotniej z 20 na 21 VI 1941 r., kiedy to światło reflektorów szeroko rozlewające się po niebie i huk armat obudził nas znienacka ze spokojnego snu. Gdy ludzie dookoła pojąć nie mogli co się stało, mogłam im z całym spokojem wytłumaczyć w oparciu o to, co parę tygodni przedtem zasłyszałam: „To wojna Niemców ze Sowietami!”

Zaraz tejże samej nocy w niedzielę 21 czerwca 1941 r. rozpoczęło się oblężenie Lwowa przez Niemców, które trwało przeszło tydzień. Strzały cekaemowskie armatnie nie cichły ani we dnie ani w nocy na ulicach wybuchały granaty. Wkrótce zabrakło gazu, potem i światła - tramwaje przestały chodzić. Mieszkałam wtedy już pod stokami Cytadeli $^{161}$ przy ulicy Supińskiego 28. Co dzień piechotą musiałam

161 Lwowska Cytadela - wzniesiona przez władze austriackie w poł. XIX w. jako element systemu fortyfikacji miasta. 
podążać przez plac św. Zofii ulicami Jabłonowskich, Zieloną, Piekarską do Kliniki Chirurgicznej przy ul. Pijarów 4. Była to przeprawa nader niebezpieczna wśród wybuchów szrapneli i nieustannej strzelaniny, od obowiązku tego jednak nie można się było uchylić. Szpital bardziej niż kiedykolwiek potrzebował rąk do pracy - nieustannie zwożono rannych z bombardowań, a nawet i z frontu.

W tym właśnie czasie, była to - pamiętam - środa 24 czerwca przed południem spotkałam przy ul. Trybunalskiej ks. kanonika Badeniego $^{162}$, który w te słowa odezwał się do mnie „Wie Pani co, wielu księży zostało dziś zwolnionych z więzienia"** Niech Pani pójdzie zobaczyć może i ks. Bogdanowicz już jest w domu, bo ks. Kwapiński ${ }^{163}$ na pewno już powrócił’. Udałam się natychmiast do ks. Kwapińskiego, który zamieszkiwał w tym samym domu co i ks. Bogdanowicz

\footnotetext{
* Wiedziałam skądinąd o tym, że ogółem odsiadywało wtedy w więzieniach lwowskich kilkudziesięciu księży tak obrządku łacińskiego, jak i ormiańskiego oraz unickiego. Podawano nawet ich liczbę: pierwszych miało być 38, ostatnich 14. Ze znanych mi nazwisk wiem, że wśród księży obrządku łacińskiego był sekretarz J[ego] E[kscelencji] Ks. Arcybiskupa Twardowskiego ks. [Jan] Schiller (i ten nie wrócił), był ks. Włodzimierz Cieński proboszcz kościoła św. Marii Magdaleny. Z księży obrz[ądku] greckokatolickiego był proboszcz cerkwi Piotra i Pawła, którego po wkroczeniu Niemców znaleziono ukrzyżowanego na murze w więzieniu przy ul. Łąckiego. ${ }^{162}$ Henryk Badeni (1884-1943), święcenia kapłańskie w 1908 r. we Lwowie, dr teologii, jako wikariusz pracował w parafii Chodorów, Złoczów, Kołomyja oraz w lwowskiej katedrze, kanonik gremialny Kapituły Metropolitalnej ob. łac. we Lwowie (1914-1943), oficjał Sądu Metropolitalnego tamże, protonotariusz apostolski. Kościół rzymskokatolicki i Polacy w Małopolsce Wschodniej podczas wojny ukraińsko-polskiej 1918-1919. Źródła, t. 2, oprac. J. W o 1 c z a ń s k i, Lwów-Kraków 2012, s. 295.

163 Wiktor Kwapiński (1883-1957) - ur. w Miechowie w rodzinie rzymskokatolickiej, święcenia kapłańskie przyjął w 1908 r. w Zgromadzeniu Księży Misjonarzy św. Wincentego a Paulo, w 1912 r. inkardynowany do lwowskiej archidiecezji ormiańskokatolickiej, był wikariuszem parafii w Czerniowcach i dyrektorem Bursy im. abp. Izaaka Isakowicza, w okresie I wojny światowej kapelan Legionów Polskich, w l. 1922-1933 administrator parafii w Brzeżanach, w 1933 r. mianowany kanonikiem gremialnym kapituły ormiańskiej we Lwowie, pracował także w Kurii Arcybiskupiej i Sądzie Arcybiskupim oraz był dyrektorem banku Mons Pius. W kwietniu 1940 r. aresztowany przez NKWD i osadzony w wiezieniu „Brygidki”, skąd zbiegł 24 VI 1941 r. W 1945 r. ponownie aresztowany przez Sowietów i skazany na 10 lat łagrów oraz konfiskatę mienia i pozbawienie praw publicznych, w 1948 r. zwolniony i wydalony do Polski. Pracował duszpastersko na Dolnym Śląsku, gdzie zmarł w Międzylesiu, pochowany w Miechowie T. K r z y ż o w s k i, Archidiecezja lwowska obrządku ormiańskokatolickiego, s. 79-81, 157, 184, 188-189, 202-204, 211, 226-227, 309, 313, 315, 318-319, 324-325, 332, 340-341, 359, 404, 421, 532, 577; T. Z a l e s k i, Słownik biograficzny, s. 68.
} 
(przy ul. Skarbkowskiej 12) o piętro niżej. Zastałam go leżącego w łóżku, bardzo zmienionego po kilkutygodniowym pobycie w więzieniu. Przywitał mnie słowami: „Dziwię się, że nie ma jeszcze ks. Bogdanowicza w domu. Już dziś o g[odzinie] 2.po północy byliśmy wolni - ja tu od razu przyszedłem, ale on mówił, że trzeba wprzód uwolnić innych współwięźniów i zabrał się wraz z innymi zwolnionymi księżmi do roboty. Nam księżom otworzyła bramy więzienne grupa studentów, która wpadła do więzienia w chwili, gdy ustąpiła straż. Sytuacja Sowietów stałą się bowiem dzisiejszej nocy tak krytyczna, że się zaczęli wycofywać zamknąwszy wprzód skrzętnie wszystkie odrzwia więzienne!’ Tyle mi zreferował ks. Kwapiński. Po tych wieściach trudno mi było zrozumieć, co się mogło stać z ks. Bogdanowiczem. Czekałam z godziny na godzinę, a potem $\mathrm{z}$ dnia na dzień na spotkanie z nim, lecz na próżno.

W poniedziałek dn[ia] 29 VI 1941 r. wczesnym rankiem od strony rogatki Łyczakowskiej wkraczali Niemcy do Lwowa ${ }^{164}$. Gdy wychodziłam z dyżuru nocnego natknęłam się na forpoczty Wehrmachtu. Zaraz rozeszła się po Lwowie wiadomość, o której już w niedzielę ludzie szeptali między sobą, że więzienie zamarstynowskie ${ }^{165}$ pełne jest pomordowanych więźniów. Z miejsca rzucili się ludzie na poszukiwania swoich najbliższych, których powrotu doczekać się nie mogli. Poszłam i ja, by się czegoś dowiedzieć o ks. Bogdanowiczu. Do śmierci nie zapomnę strasznego widoku, jaki oczom moim się przedstawił. Wszędzie pełno trupów. W suterenach ułożeni warstwami - jak śledzie w beczce - jeden na drugim pomordowani, kurczowo trzymający się siebie, widocznie jeszcze żywcem zmuszeni do zajęcia takich pozycji; każdy miał strzał w skroń: wlot kuli z jednej strony, wylot $\mathrm{z}$ drugiej strony czoła. Był upał - trupy leżące tak od kilku dni już,

164 Błąd autorki; przez rogatkę łyczakowską opuszczały Lwów wojska sowieckie. 30 VI 1941 r. oddziały Wehrmachtu i SS wkraczały do Lwowa od Przedmieścia Gródeckiego, Przedmieścia Żółkiewskiego i Persenkówki. Do miasta wraz z oddziałami niemieckimi wszedł także współpracujący z nazistami batalion ukraiński „Nachtigall”. Kronika 2350 dni wojny i okupacji Lwowa 1 IX 1939-5 II 1946, oprac. G. M a z u r, J. S k w a r a, J. W ę g i e r s k i, Katowice 2007, s. 202.

165 Więzienie we Lwowie w dzielnicy Zamarstynów, od 1939 do 1941 i od 1944 roku więzienie polityczne NKWD. Właściwa dzielnica Zamarstynów rozciągała się za torami (patrząc od miasta) i do 1931 było wsią podmiejską. Więzienie było przy ul. Zamarstynowskiej, ale potocznie mówiono, że znajduje się na Zamarstynowie. 
były w rozkładzie. Nie pomogło trzymanie chustki przy nosie, raz po raz zrywało na wymioty. Dużo ludzi włożyło maski przeciwgazowe nie mogąc znieść tego fetoru. Na podwórzu więziennym leżało pełno trupów zmasakrowanych tak, że nie było możliwości zidentyfikować ich. Jedni z wyrwanymi językami, zastygli tak jak byli z ustami otwartymi do krzyku, inni z oczami wyłupanymi, z rękami odciętymi. Twarze ich były tak obrzmiałe i zniekształcone, że trudno się było zorientować i poznać kogokolwiek z wyglądu. Cele więzienne były opróżnione. Wśród napływających tam ciągle od zewnątrz ludzi, znalazł się jeden, który uprzednio odsiadywał $\mathrm{w}$ tym więzieniu i uratował się dzięki temu, że go wcześniej zwolniono. Z rozmowy z nim dowiedziałam się, że był w jednej celi $\mathrm{z}$ ks. Bogdanowiczem ${ }^{166}$, zaprowadził mnie do tej celi (wielkości $5 \mathrm{~m}$ x $5 \mathrm{~m}$ ) na parterze. Miało tam odsiadywać karę 40 osób, a tak im było ciasno, że część z nich musiała stać [z] braku miejsca. Człowiek ten wspominając ks. Bogdanowicza jedno tylko wciąż powtarzał: „Nie było na co patrzeć!” Chciał przez to powiedzieć, jaki on był wynędzniały. W celi tej znajdował się, już tylko jako jedyny sprzęt, kibel wypróżniony i kilka misek tak ohydnych, że człowiek nie odważyły się ani nawet psu podać w nich jedzenie. Puściłam się na dalsze poszukiwania i w jednej z cel więziennych, na piętrze, znalazłam sutannę kapłańską - żeby natrafić na jakiś ślad przeszukałem wszystkie kieszenie, ale nie znalazłam nic prócz mocno zanieczyszczonego grzebienia gęstego. Chodziłam tak przez szereg dni na poszukiwanie do tego więzienia na Zamarstynowie - więzienie Brygidek na Kazimierzowskiej było spalone. Po każdej takiej wizycie, na wpół żywa chroniłam się do domu jednej znajomej mieszkającej opodal, przy ul. Ogrodniczej. Ona z miejsca zdejmowała ze mnie całe ubranie, by je przewietrzyć na podwórzu, a mnie kładła do swego łóżka, żebym przyszła do siebie. Dopiero po kilkugodzinnym odpoczynku byłam $\mathrm{W}$ stanie puścić się $\mathrm{W}$ drogę powrotną piechotą do domu, bo tramwaje nie były jeszcze uruchomione.

Podczas jednej z tych wizyt w więzieniu Zamarstynowskim, byłam świadkiem jak Niemcy demonstrowali przed amerykańską Komisją

\footnotetext{
166 Prawdopodobnie świadek, z którym rozmawiała Maria Kapri pomylił ks. Bogdanowicza $\mathrm{z}$ innym duchownym, gdyż nic nie wskazuje na to, aby przebywał on w więzieniu na Zamarstynowie.
} 
Czerwonego Krzyża ${ }^{167}$ straszne ślady bestialskich mordów dokonanych przez Sowietów. Ameryka jeszcze wtedy nie była w wojnie z Niemcami. Nazajutrz wzięto się do grzebania umarłych na tymże dziedzińcu więziennym. Spędzono $\mathrm{w}$ tym celu na to miejsce dużą ilość Żydów, nad którymi z kolei Niemcy okrutnie się pastwili zmuszając ich biciem i kopaniem do kopania dołów i grzebania ciał pomordowanych.

Mimo wszystkich moich wysiłków nie dowiedziałam się niczego konkretnego.

Pracowałam wtedy nadal w szpitalu. Jednego z najbliższych dni, podczas dyżuru nocnego, pełniąca wtedy ze mną służbę s[iostra] Szarytka powiedziała mi, bym się udała do klasztoru ukraińskich Studytek ${ }^{168}$, bo tam od jednej z zakonnic (siostry Ołeny Witer ${ }^{169}$ ) będę mogła się czegoś konkretnego dowiedzieć o ks. Bogdanowiczu. Zaraz nazajutrz pośpieszyłam tam do ich klasztoru, położonego niedaleko cerkwi Piotra i Pawła. Na moją prośbę wyszła do mnie do rozmownicy zakonnica, która duże na mnie wywarła wrażenie. Twarz jej pełna wyrazu, podobna do męczennicy z obrazka, nosiła na sobie wyraźnie piętno przebytych mąk. Po przywitaniu się ze mną, gdy jej po-

167 Amerykański Czerwony Krzyż - organizacja powstała w 1881 r. z siedzibą w Waszyngtonie. Zajmuje się niesieniem pomocy ofiarom wojen i kataklizmów; należy do Międzynarodowego Czerwonego Krzyża. Na terenach okupowanych przez Niemców działalność Czerwonego Krzyża była mocno ograniczona. Mimo to w celach propagandowych Komisje Czerwonego Krzyża były czasami dopuszczane, aby zademonstrować opinii publicznej humanitarne podejście Niemców, a zarazem pokazania zbrodni, jakich dopuszczali się Sowieci.

${ }^{168}$ Studytki - greckokatolicki zakon żeński działający m.in. we Lwowie.

${ }^{169}$ Olena Witer (1904-1988) - greckokatolicka zakonnica, studyta, w zakonie Josifa, zaangażowana w działalność społeczną jako organizatorka przedszkoli, sierocińców i bibliotek, w 1. 1939-1940 przełożona studytek we Lwowie. 11 VI 1940 r. aresztowana przez NKWD za współpracę z Organizacją Ukraińskich Nacjonalistów i skazana na karę śmierci. Po wkroczeniu Niemców do Lwowa i wycofaniu się Sowietów w czerwcu 1941 r. uciekła z więzienia. Aresztowana ponownie przez NKWD w 1945 r. za pomoc działaczom OUN i UPA oraz skazana na 20 lat katorgi. Po wyjściu z łagrów w 1956 r. dołączyła do wspólnoty studytek działającej wówczas w konspiracji. Pracowała w Skałacie i Lwowie angażując się w pomoc charytatywną. W 1976 r. otrzymała tytuł Sprawiedliwy Wśród Narodów Świata; zrehabilitowana przez władze ukraińskie w 1995 r. Н. С т а н ь к о в с ь к а, І. Ф е д е ч к о, Йосифа Вітер Олена Василівна, [w:] Тернопільський Енииклопедичний Словник, т. 1, ред. Г. Яв орськй, Тернопіль 2004, s. 692-693. 
wiedziałam, w jakiej sprawie przyszłam do niej, w te odezwała się do mnie słowa: „Wy jesteście Polką, więc mówcie do mnie po polsku. Ja jestem Ukrainką, więc będę do was mówić po ukraińsku”. Gdy ją zapytałam, co ona wie o księdzu Bogdanowiczu, odpowiedziała bez chwili wahania; ,Zhynuł - na pewno zhynuł!” (Zginął, na pewno zginął!) I zaczęła mi opowiadać jak się to wszystko odbyło: „Ks. Bogdanowicz w środę rano przed świtem (dn[ia] 24 VI) był już wolny. Ekipa studentów dowiedziawszy się NKWD-ziści opuścili teren więzienia (Brygidek przy ul. Kazimierzowskiej) natychmiast wdarli się do środka i wyłamali drzwi od celi, w której przesiadywali księża uwalniając ich wszystkich. „Błagałam ks. Bogdanowicza - ciągnęła dalej s[iostra] Ołena - „by się udał niezwłocznie do domu. Ale on mi odpowiedział: „Nie ruszę się stąd, aż nie będą wolni i tamci więźniowie”. I od razu zabrał się do dzieła przy pomocy innych księży, do których wkrótce się dołączyli i inni ,specjaliści” od wyważania drzwi i otwierania zamków (tj. włamywacze, którzy tam odsiadywali karę). Między godziną 2:00 a 4:00 cały szereg cel więziennych zostało tym sposobem otwartych i bardzo wielu więźniów mogło powrócić do domu. Po g[odzinie] 4:00 jednak - gdy się najwidoczniej poprawiła sytuacja Sowietów - NKWD powróciło na teren więzienia.

Zobaczywszy wtedy co się dzieje i zastawszy księży przy tej robocie, straszliwą im sprawili rzeź. Do więzienia weszły komsomołki (młode stosunkowo dziewczęta), zbrojne w pistolety, noże i inne narzędzia zagłady i wtedy zaczęła się masakra. „Mnie kazali oprawcy” - mówi s[iostra] Ołena - „obrócić się licom ku zemli (twarzą do ziemi), więc tylko przez chwilę widziałam jak atakowały księży, jak ci padali pod ich razami. Potem tylko słyszałam ich głośne wołania: „Jezus! Maria!”, ich jęki i przedśmiertne rzężenia. Gdy wstałam, już wszyscy leżeli - zapędzono mnie wraz z innymi obecnymi tam więźniarkami do obszernej celi na parterze. Tam nas zamknięto i tam o głodzie - bo już nie podano nam żadnego jedzenia, ani picia - przesiedziałyśmy cały czwartek i piątek. W piątek wieczór wszedł do naszej celi jeden z NKWD-zistów w towarzystwie rzeźnika, po dokonaniu oględzin, rzeźnik* w te słowa odezwał się do mnie: „Sestra Ołena, zawtra, wy budiety szczasna - pijdety

\footnotetext{
* Był to podobno znany rzeźnik lwowski - Żyd, który pomagał Sowietom w mordowaniu więźniów. Jak mówiono, rzeźnika tego schwytali Niemcy w chwili, gdy uciekał ze Lwowa przez rogatkę Łyczakowską. Zidentyfikowali go i stracili.
} 
do Otca Nebeskoho" (Siostro Oleno, jutro będziecie szczęśliwa, pójdziecie do Ojca Niebieskiego). Zrozumiałam, że nazajutrz sądzoną mi była śmierć, jak i zapewne wszystkich moim towarzyszkom. I rzeczywiście nazajutrz, wczesnym rankiem $\mathrm{w}$ okienku w drzwiach (w tzw. Judaszu) ukazała się lufa karabinowa i zabrzmiał rozkaz: „Zbyrajty sia!” (Zbierajcie się!) Więźniarki w przeczuciu co ich czeka, uderzyły w płacz. Miałam w woreczku na szyi konsekrowane Komunikanty, które uprzednio otrzymałam była od ks. Bogdanowicza. Rozdałam im Pana Jezusa, wzbudziwszy wprzód krótki akt żalu. Uspokoiły się nieco. Prosiłam ich, by się ubierały jak najwolniej. Zapytałam stojącego za drzwiami strażnika, czy mamy się obuć? „Berty czoboty” odrzekł (Weźcie na siebie buciki!) Wtem jakaś ostra komenda dała się słyszeć na korytarzu, lufa wycofała się z okienka - nastała głęboka cisza. Po kilku minutach byłyśmy już gotowe, ale nikt nas nie napędzał do odejścia. Czekałyśmy godzinę, dwie - nikt się nie pojawił. Próbujemy klamki... drzwi zamknięte... zaczynamy nieśmiało pukać do drzwi... cisza... uderzamy nogami... żadnej odpowiedzi. W tym stanie oczekiwania przetrwałyśmy do wieczora. Nagle hałas na korytarzu... wyłamywanie drzwi. Przed nami stoi kilku młodzieńców. Każą wychodzić pospiesznie, natychmiast. Żadna z nas nie reaguje, nie śmie się ruszyć. Straszne widziadła sprzed kilku dni, masakra za próbę ucieczki jeszcze stoi w pamięci i dech zapiera w piersiach. Wtedy ci młodzi odważni chwytają nas pod ręce i siłą wypychają za bramy więzienne, na ulicę, na wolność. Każda podążyła swoją drogą - ja pospieszyłam prosto do Metropolity*. Na górze, cele Brygidek, w których przed paru dniami odbyła się masakra księży, widać dla zatarcia śladów, zapalone - płonęły!”

Gdy usłyszałam te ostatnie słowa, przypomniałam sobie moje widzenie nocne i usłyszany głos: „Moje ciało jest pod płonącą belką”.

Tak Adasiu, wraz z ciałem Twoim złożyłeś Bogu w ofierze całopalnej i życie swoje. To o co co dzień modliłeś się po Komunii św. otrzymałeś jak mi to sam kiedyś wyznałeś; otrzymałeś: łaskę męczeństwa.

Skończyły się te Twoje wzloty niebotyczne ku górze, bo się okazałeś godnym oddać Bogu wszystko bez reszty, żeby Go sobie zdobyć na wieki.

I tu przypominają mi się słowa, które szereg lat wstecz napisałeś do mnie w liście z 3 XII 1924 r.:

\footnotetext{
*J[ego] E[kscelencja] Ks. Metr[oplita] Szeptycki.
} 
„Przyznam Ci się, że jestem zanadto „Sans façon” ${ }^{170}$ z Panem Jezusem: 99\% katolików zgorszyłoby się drodze, gdyby mogli wiedzieć jak ja się zachowuje i co mówię P[anu] Jezusowi - ja zaś nie mam najmniejszych skrupułów. Powiedziałem $\mathrm{Mu}$ raz na zawsze, że nie chcę być „dorosłym” z Nim, że chcę być zawsze Jego ,piccolo" ${ }^{171}$ i to w dodatku ,enfant terrible"172, któremu nie tyle wszystko wolno, ile sobie sam na wszystko pozwala - a że się warunki tak ułożyły, iż Jezus jest mi istotnie wszystkiem: rodziną i przyjacielem, więc jestem tym swobodniejszy, bo On nie może się uchylić, musi mi wszystkim być; być cierpliwym, gdy jestem krytycznie nastrojonym i uśmiechać się, gdy się we mnie dowcipna struna odzywa!"

Rozumiem, więc jako to „enfant terrible” tyś jednym wielkim skokiem zdobył sobie niebo - zagarnąłeś je - nikogo wiele o nic nie pytając, podczas gdy my z podziwu wyjść nie możemy, że się to Tobie tak udało.

I nic nam już innego nie pozostaje, jak tylko zwrócić się do Ciebie $\mathrm{z}$ tą inwokacją, widniejącą w katakumbach na grobach męczenników:

„Żyj w pokoju i wstawiaj się za nami!"

Tu chciałaby dodać na zakończenie jeszcze kilka słów o Matce ks. Bogdanowicza.

Spędziwszy 9 pełnych lat w ciągłym oczekiwaniu na powrót ukochanego swego jedynaka, trawiona niewymowną tęsknotą za nim zapadła poważnie na zdrowiu - jakiś ból nieokreślony w nogach coraz bardziej dawał się jej we znaki. Okazało się, że była to gruźlica kości. Ona też położyła kres jej życiu, gdy już była doszła do 80. roku. Dnia 15 VIII 1949 r. stan jej znacznie się pogorszył - leżała u brata swego Tadeusza Bohdanowicza ${ }^{173}$ w Krakowie przy ul. Lokietka. Zawezwano do niej orm[mińskiego] księdza Jakubowicza ${ }^{174}$, on jej

\footnotetext{
${ }^{170}$ Fr.: bezceremonialny.

171 Wł.: mały.

${ }^{172}$ Fr.: osoba nietaktowna, łamiąca przyjęte reguły.

173 Tadeusz Bohdanowicz (1880-1961), ur. w Orzechlibach na Bukowinie w rodzinie ormiańskiej Grzegorza i Rozalii Zadurowicz, przedsiębiorca. Ożeniony z Łucją Odrowąż-Pieniążek, z którą miał troje dzieci: Irenę, Tadeusza i Jana. Mieszkał w Krakowie w willi na Krowodrzy, prowadził Fabrykę Puszek i Wyrobów Tłoczonych z Blachy. Zmarł w Krakowie i został pochowany na Cmentarzu Rakowickim. Krakowska Księga Adresowa na rok 1908, red. J. K n a p i k, Kraków 1908, s. 57; Relacja ustna Stanisława Łazarskiego, Kraków 14 IX 2020 r.

174 Franciszek Jakubowicz (1907-1972) - ur. w Suczawie w rodzinie ormiańskiej Krzysztofa i Heleny, w 1939 r. wyświęcony na kapłana dla lwowskiej archidiecezji
} 
podał Wiatyk. Po przyjęciu Go nagle się zerwała, wyciągnęła ręce jakby kogoś witała, na twarzy jej widoczną była jakaś radość niewypowiedziana - chwilę trwała w tym niemym zachwycie, potem opadła na poduszki i wydała ostatnie tchnienie.

Obecni przy tym świadkowie byli pewni, że przyszedł po nią jej Syn ukochany, by ją zabrać tam do siebie, do tych przybytków wiekuistego szczęścia, gdzie już nie ma bólu rozstania ani cierpień żadnych.

Był to dzień święta Wniebowzięcia N[ajświętszej] M[aryi] P[anny] 1949 r.

Zaświadczam, że powyższe wspomnienia są przeze mnie osobiście napisane. Maria Kapri, Opole, 4 V [19]85

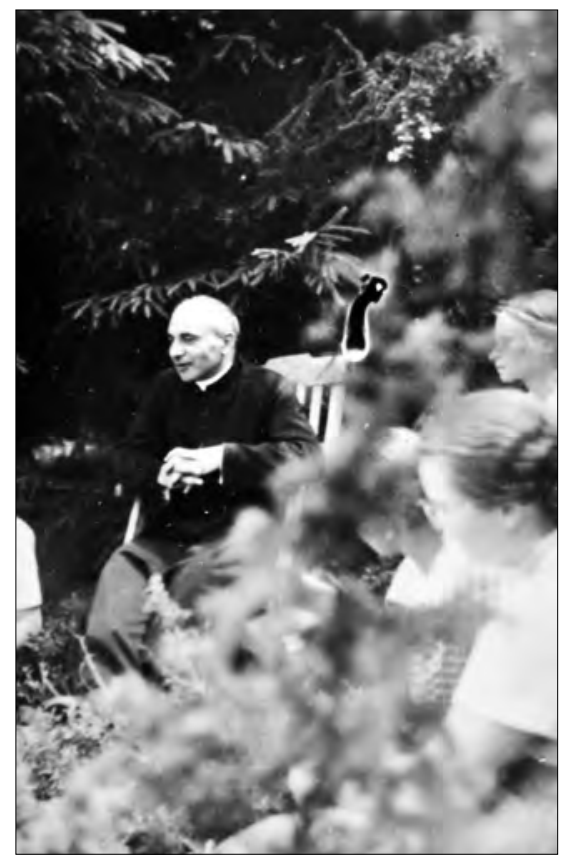

6. Ks. Adam Roszko-Bogdanowicz podczas rekolekcji w Bukowinie Tatrzańskiej, lipiec $1939 \mathrm{r}$.

ormiańskokatolickiej przez abp. Andrzeja Szeptyckiego, wikariusz katedry ormiańskiej (1939-1945), pracował także w Kurii Arcybiskupiej i Sądzie Arcybiskupim. W 1945 r. zamieszkał w Krakowie, gdzie w kościele pw. św. Idziego sprawował Msze św. w obrządku ormiańskim. Pochowany na Cmentarzu Rakowickim w Krakowie. T. Z a l e s k i, Słownik biograficzny, s. 53. 


\section{BIBLIOGRAFIA}

\section{Źródla archiwalne}

\section{Archivio Apostolico Vaticano}

Arch. Nunz. Varsavia 273, fasc. 1134, Pismo ks. Adama Bogdanowicza do ks. Alfredo Paciniego, Kossów 16 V 1936.

\section{Archiwum Abpa Eugeniusza Baziaka w Krakowie}

b.sygn., Staudt H., Ks. Adam Bogdanowicz realizator wskazań liturgicznych

Piusa X, Kraków 1975, mps.

\section{Archiwum Diecezji Opolskiej w Opolu}

b.sygn., Kopia listu Jadwigi Knaus do Marii Kapri, Kraków 3 V 1985.

Oświadczenie Anny Sędziwy, Kraków 6 V 1985.

Archiwum Fundacji Kultury i Dziedzictwa Ormian Polskich w Warszawie b.sygn., Wspomnienia o ks. Adamie Roszko Bogdanowiczu.

\section{Archiwum Wydziału Teologicznego Uniwersytetu Opolskiego}

sygn. 14/89/2009, P. Skupień, Adam Bogdanowicz (1898-1941) - kapłan, działacz narodowy, męczennik, Opole 2009.

\section{Zbiory Autora w Krakowie}

b.sygn., Materiały zebrane przez Magdalenę Bernacką i Dariusza Łazarskiego podczas kwerendy w $2015 \mathrm{r}$.

b.sygn., List s. Janiny Martynuski CSIC do autora, Szymanów 28 I 2019.

\section{Źródła drukowane}

Kościót rzymskokatolicki i Polacy w Małopolsce Wschodniej podczas wojny ukraińsko-polskiej 1918-1919. Źródła, t. 2, oprac. J. Wołczański, LwówKraków 2012.

Krakowska Księga Adresowa na rok 1908, red. J. Knapik, Kraków 1908. Kronika Pokucka, „Goniec Pokucki”, 1907, nr 40, s. 4.

Krzyżowski T., Korespondencja arcybiskupa ormiańskokatolickiego Józefa

Teodorowicza z Prymasem Polski kardynałem Augustem Hlondem z lat 1924-1938, „Lehahayer. Czasopismo Poświęcone Dziejom Ormian Polskich”, 2019, nr 6, s. 165-296.

Nekrolog prof. Marii Kapri, „Tygodnik Powszechny”, 1985, nr 25, s. 2.

Polska i Ukraina $w$ latach trzydziestych-czterdziestych XX wieku. Nieznane dokumenty z archiwów stużb specjalnych. Polskie Podziemie 1939-1941, t. 1: Lwów-Kołomyja, Stryj-Złoczów, red. Z. Gajowniczek, WarszawaKijów 1998.

Polskie Ogniska Wychowawcze Wiejskie. Zasady i środki. Program pierwszego polskiego Ogniska Wychowawczego Wiejskiego dla chłopców, Lwów 1906. Schematismus archidioecesis leopoliensis ritus armeno-catholici pro Anno Domini 1926, Leopolis 1926. 
Wołczański J., Korespondencja abp. Józefa Teodorowicza z abp. Adamem Stefanem Sapieha z lat 1901-1938, [w:] Arcybiskup Józef Teodorowicz (1864-1938). Studia i materiały, red. J. Wołczański, Kraków 2017, s. 245-425.

\section{Opracowania}

Albert Z., Lwowski Wydział Lekarski w czasie okupacji hitlerowskiej 1941-1944, Wrocław 1975.

B[łotnicki] F., rec.: Savinian Louismet, Życie mistyczne, Lwów 1927. Nakładem i drukiem Tow[arzystwa] „Biblioteka Religijna”, str. 212, „Gazeta Kościelna", 1927, nr 7, s. 82.

Bogdanowicz A., Częsta Komunia św. a częstość spowiedzi wiernych w praktyce duszpasterskiej, Lwów 1938.

Brzozecki S., Petitot Henri, [w:] Encyklopedia katolicka, t. 15, red. E. Gigilewicz, Lublin 2011, kol. 390 Brzozecki S., Tomasz z Akwinu, w: Encyklopedia katolicka, t. 19, red. E. Gigilewicz, Lublin 2013, kol. 848-849.

Chodynicki H., Polskie Ognisko Wychowawcze Wiejskie (1906-1914), [w:] Eksperymenty pedagogiczne $w$ Polsce w latach 1900-1939, red. B. Nawroczyński, Wrocław 1963, s. 33-51.

Dzwonkowski R., Leksykon duchowieństwa polskiego represjonowanego w ZSRS 1939-1988, Lublin 2003.

Gajewski S., Iuventus Christiana, [w:] Encyklopedia katolicka, t. 7, red. J. Duchniewski, Lublin 1997, kol. 564-566.

Grodziski S., Sejm Krajowy Galicyjski 1861-1914, Kraków 2018.

Grzebień L., Bogdanowicz Adam, [w:] Stownik polskich teologów katolickich 1918-1981, t. 5, red. L. Grzebień, Warszawa 1983, s. 147-148.

Ihnatowicz I., Projekt instrukcji wydawniczej dla źródet historycznych XIX i początku XX wieku, ,Studia Źródłoznawcze”, t. 7, 1962, s. 99-124.

Jazłowiec, Jazłowiec 1938.

Kara J., Podstawka J., Stownik biograficzny moderatorów i profesorów, [w:] Wyższe Seminarium Duchowne w Nysie-Opolu 1949-1999. Księga Jubileuszowa, red. K. Dola, J. Waloszek, Opole 2000, s. 79-111.

Klauza K., Garrigou-Lagrange Réginald, [w:] Encyklopedia katolicka, t. 5, red. P. Hemperek, Lublin 1989, kol. 873-874.

Klein F., Une expérience religieuse: Madeleine Sémer, convertie et mystique (1874-1921), Paris 1923.

Konarski S., Gralewski Jan, [w:] Polski Stownik Biograficzny, t. 8, red. K. Lepszy, Wrocław-Kraków-Warszawa 1959-1960, s. 538-540.

Konieczny M., Żychliński Aleksander, [w:] Encyklopedia katolicka, t. 20, red. E. Gigilewicz, Lublin 2014, kol. 1623-1624.

Kotarska E., Proces czternastu, Warszawa 1998.

Kronika 2350 dni wojny i okupacji Lwowa 1 IX 1939-5 II 1946, oprac. G. Mazur, J. Skwara, J. Węgierski, Katowice 2007. 
Krzyżowski T., Archidiecezja lwowska obrzadku ormiańskokatolickiego w latach 1902-1938, Kraków 2020.

Krzyżowski T., Kresowy głos sumienia. Arcybiskup Józef Teodorowicz (18641938), „Biuletyn IPN”, 2019, nr 10, s. 11-22.

Krzyżowski T., Kulisy nominacji następcy ormiańskokatolickiego arcybiskupa Lwowa Józefa Teodorowicza, „Lehahayer. Czasopismo Poświęcone Dziejom Ormian Polskich", 2018, nr 5, s. 249-263.

Leszczyński M., Liga Katolicka, [w:] Encyklopedia katolicka, t. 10, red. E. Ziemann, Lublin 2004, kol. 1035-1037.

Łoza S., Czy wiesz kto to jest?, Warszawa, 1938.

Marciniak K., Gardeil Ambroise, [w:] Encyklopedia katolicka, t. 5, red. P. Hemperek, Lublin 1989, kol. 864-865.

Metropolita Andrzej Szeptycki. Studia i materiały, red. A. A. Zięba, Kraków 1994. Mysiakowska-Muszyńska J., „W imię Boga i Ojczyzny”. Działalność społeczno-polityczna Narodowej Organizacji Kobiet 1919-1939 - wybrane zagadnienia, „Dzieje Najnowsze”, 47(2015), nr 3, s. 25-48.

Nespiak D., Tadeusz Ostrowski, „Wrocławskie Studia Wschodnie”, 2018, t. 22, s. 253-267.

Nitecki P., Biskupi Kościoła w Polsce w latach 965-1999. Stownik biograficzny, Warszawa 2000.

NKWD, Narodnyj komissariat wnutriennich diel, Ludowy Komisariat Spraw Wewnętrznych, [w:] Wielka Encyklopedia PWN, t. 19, red. J. Wojnowski, Warszawa 2003, s. 91.

Orłowski M., Generat Józef Haller 1873-1960, Kraków 2007.

Осіньчук Р., Паньчишин Маріян, [w:] Енциклопедія украӥнознавства. Словникова частина, т. 5, ред. В. Кубійович, Париж-Нью-Йорк 1966, s. 1940.

Pawlina S., Błotnicki Franciszek, [w:] Encyklopedia katolicka, t. 2, red. F. Gryglewicz, Lublin 1976, kol. 686-687.

Petitot L. H., Sainte Thérèse de Lisieux: une renaissance spirituelle, Paris 1925.

Petitot L. H., Święta Teresa z Lisieux: odrodzenie duchowe, Przemyśl 1927.

Pohorecki F., Bohdanowicz Grzegorz, [w:] Polski Słownik Biograficzny, t. 2, red. W. Konopczyński, Kraków 1936, s. 221.

Praśkiewicz S., Teresa od Dzieciątka Jezus, [w:] Encyklopedia katolicka, t. 19, red. E. Gigilewicz, Lublin 2013, kol. 708-709.

Przybył-Sadowska E., Biblioteka Wiedzy Religijnej w Warszawie (1919-1939), „Z Badań nad Książką i Księgozbiorami Historycznymi”, 2016, t. 10, s. 211-227.

Rostworowski Jan, [w:] Encyklopedia wiedzy o Jezuitach na ziemiach Polski i Litwy 1564-1995, oprac. L. Grzebień, Kraków 1996. 
Rostworowski J., rec.: S. Louismet, Życie mistyczne, przełożyła W. Grafczyńska, Lwów „Biblioteka Religijna” 1927, str. 220, „Przegląd Powszechny”, 1927, t. 173, s. 248-249.

Rycerki Maryi. Z dziejów tułactwa sióstr wizytek lubelskich, Łuck 1936.

Smirnow J., Das Schicksal der armenisch-katholischen Kirche in Galizien während des zweiten Weltkriegs und in der Nachkriegszeit, „Resovia Sacra. Studia Teologiczno-Filozoficzne Diecezji Rzeszowskiej”, 2007/2008, nr 14-15, s. 221-239.

Stalin Józef, [w:] Rosja, red. W. Sienkiewicz, Warszawa 2001, s. 243-244.

Станьковська Н., Федечко I., Йосифа Вітер Олена Василівна, [w:] Тернопільський Енщиклопедичний Словник, т. 1, ред. Г. Яворський, Тернопіль 2004, s. 692-693.

Szeptycka A., Łoś P. S., Szeptycki Jan Leon Sylwester, [w:] Ziemianie polscy $X X$ wieku. Stownik biograficzny, cz. 7, red. J. Leskiewiczowa, Warszawa 2004, s. 154-156.

Szkoły Wyższe Rzeczypospolitej Polskiej, Warszawa 1930.

Szumowski W., Gluziński Lesław, [w:] Polski Słownik Biograficzny, t. 8, red. K. Lepszy, Wrocław-Kraków-Warszawa 1959-1960, s. 87-88.

Wasyl F., Ormianie w świetle zapowiedzi przedmatżeńskich rodzimej parafii w Kutach. Edycja źródta, cz. 1: lata 1860-1914, „Krakowskie Pismo Kresowe", 2016, nr 8, s. 93-267.

Werner A., Ocalenie z innego miejsca, Sanok 2017.

Węgierski J., Lwów pod okupacja sowiecka 1939-1941, Warszawa 1991.

Wnuk R., „Za pierwszego Sowieta”. Polska konspiracja na Kresach Wschodnich II Rzeczypospolitej (wrzesień 1939-czerwiec 1941), Warszawa 2007.

Wołczański J., Martyrologium księży ormiańskokatolickich $w$ archidiecezji lwowskiej po II wojnie światowej w świetle źródet sowieckich, [w:] Polacy w Armenii, red. E. Walewander, Lublin 2000, s. 193-219.

Wołczański J., Wydział Teologiczny Uniwersytetu Jana Kazimierza we Lwowie 1918-1939, Kraków 2002.

Wosiek R., Irena Tyszkiewiczowa - siostra Maria Franciszka (1887-1964), [w:] Ludzie Lasek, oprac. T. Mazowiecki, Warszawa 1987, s. 250-265.

Zaleski T., Stownik biograficzny duchownych ormiańskokatolickich oraz duchownych rzymskokatolickich pochodzenia ormiańskiego $w$ Polsce $w$ latach 1750-2000, Kraków 2001.

Ziemann E., Louismet Irenée Savinien, [w:] Encyklopedia katolicka, t. 10, red. E. Ziemann, Lublin 2004, kol. 1409.

Zięba A. A., Grzegorz de Oroszeny Bohdanowicz, [w:] Portrety Ormian Polskich [kalendarz na 2017 r. wydany przez Fundację Kultury i Dziedzictwa Ormian Polskich w Warszawie].

Żynel A., Franciszek z Asyżu, [w:] Encyklopedia katolicka, t. 5, red. P. Hemperek, Lublin 1989, kol. 426-427. 


\section{Relacje}

Relacja ustna Stanisława Łazarskiego, Kraków 14 IX 2020.

\section{Netografia}

Drzewo genealogiczne Roszko-Bogdanowiczów, http://www.skarbnica.ormianie.pl [dostęp: 16.09.2020].

Drzewo genealogiczne Teodorowiczów, http://www.skarbnica.ormianie.pl [dostęp: 16.09.2020].

https://cordobapedia.wikanda.es/wiki/Obispo_Fray_Albino (dostęp: 6 VII 2020). Rozalia de Oroszeny Bohdanowicz (1844-1932), www.wiki.ormianie.pl [dostęp: 14.05.2020].

Stanistaw Bogdanowicz (1867-1907), www.wiki.ormianie.pl [dostęp: 14.05.2020]. Wanda Bogdanowicz (1869-1949), www.wiki.ormianie.pl [dostęp: 14.05.2020].

\section{Wykaz fotografii}

1. Maria Kapri w swoim mieszkaniu w Opolu, lata 70. XX wieku (Zbiory Zbigniewa Bitki w Opolu).

2. Grzegorz i Rozalia de Oroszeny Bohdanowicz (Zbiory Marka Bohdanowicza).

3. Stanisław i Wanda Bogdanowicz (Archiwum Fundacji Kultury i Dziedzictwa Ormian Polskich w Warszawie).

4. Adam Roszko-Bogdanowicz, Lwów 1903 r. (Archiwum Fundacji Kultury i Dziedzictwa Ormian Polskich w Warszawie).

5. Alumn Adam Roszko-Bogdanowicz na tle katedry ormiańskiej we Lwowie (Archiwum Fundacji Kultury i Dziedzictwa Ormian Polskich w Warszawie).

6. Ks. Adam Roszko-Bogdanowicz podczas rekolekcji w Bukowinie Tatrzańskiej, lipiec 1939 r. (Archiwum Fundacji Kultury i Dziedzictwa Ormian Polskich w Warszawie).

TOMASZ KRZYŻOWSKI - doktor historii, pracownik naukowo-badawczy Ośrodka Badań nad Kulturą Ormiańską w Polsce Polskiej Akademii Umiejętności w Krakowie. Zajmuje się dziejami Ormian polskich ze szczególnym uwzględnieniem historii Kościoła ormiańskiego 